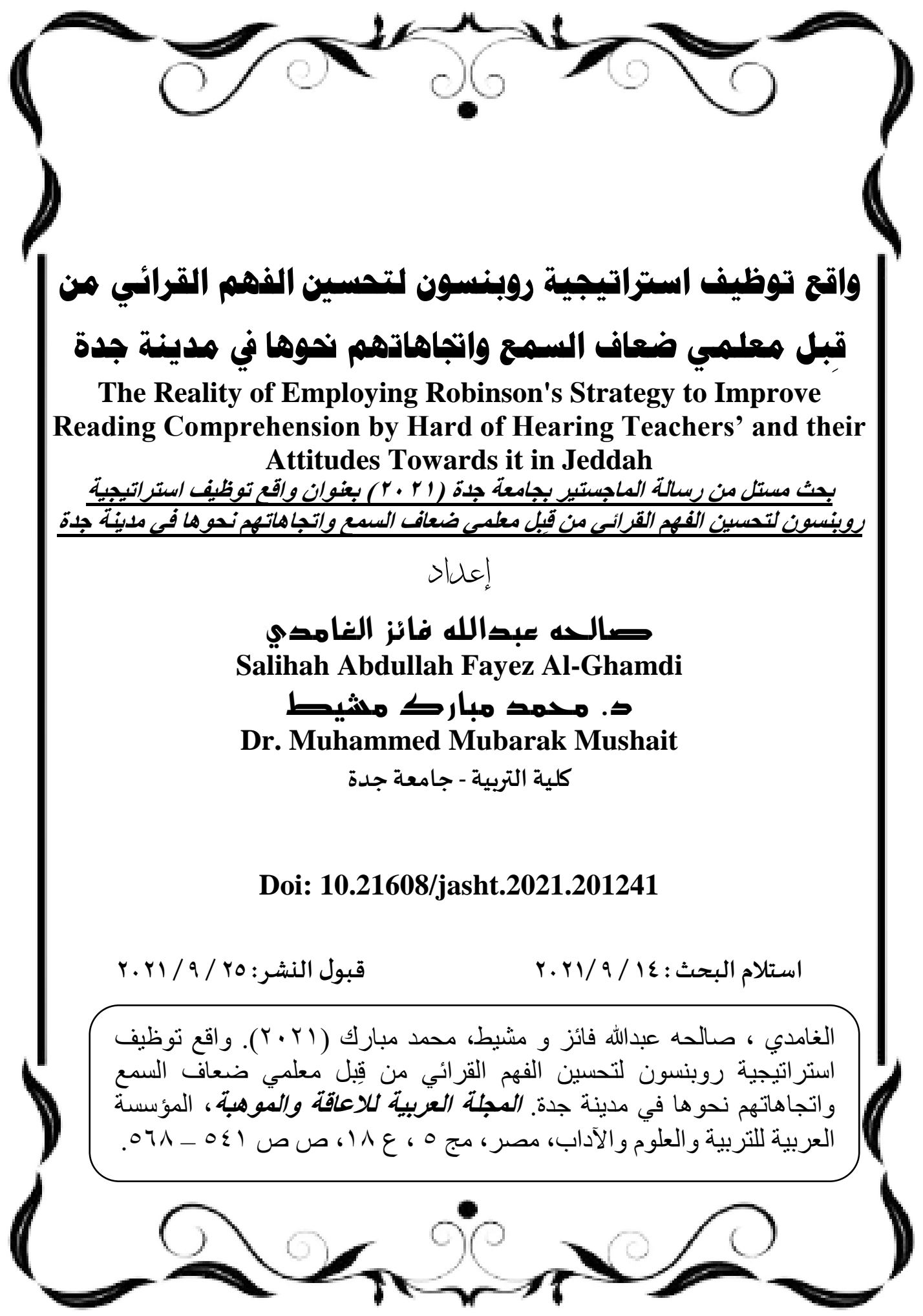




\section{واقع توظيف استراتيجية روبنسون لتحسين الفهم القرائي من قِبل معلمي ضعاف السمع واتجاهاتهم نحوها في مدينة جدة التحنة}

تهدف الدراسة الحالية إلى التَّعرُف على و اقع توظيف استر اتيجية روبنسون لتحسين

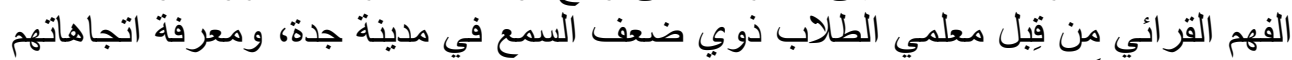

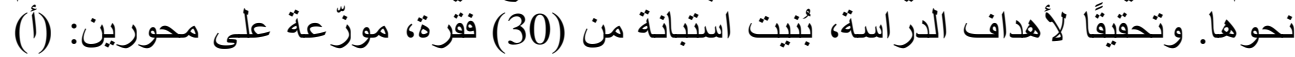

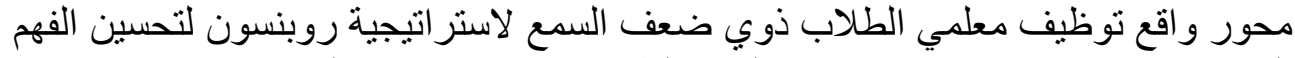

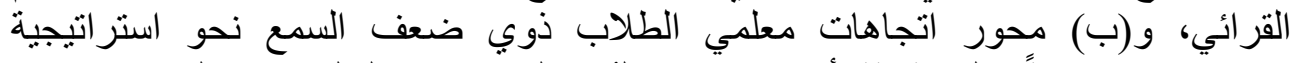

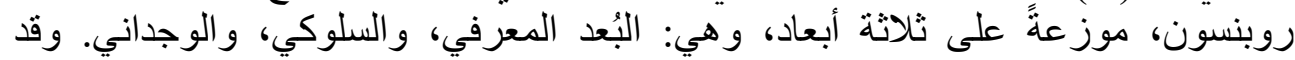

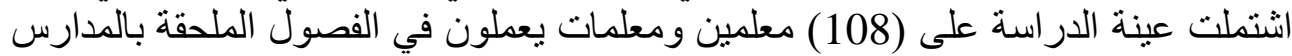

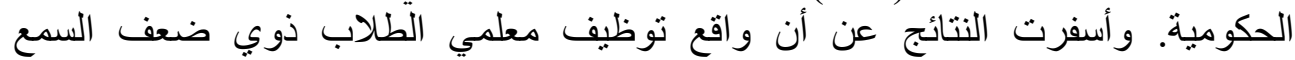

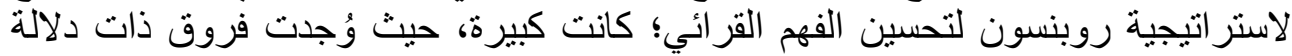

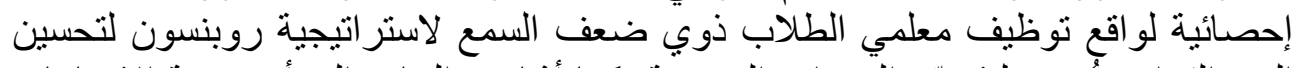

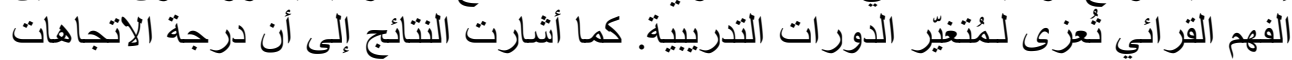

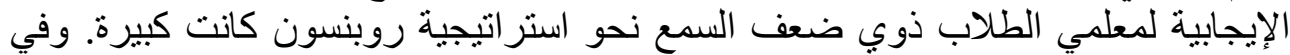

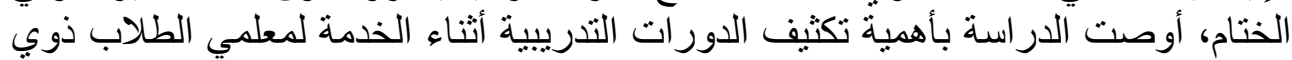

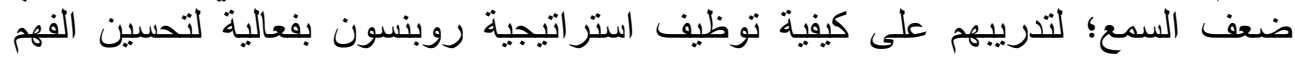

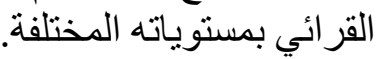
الكلمات المفتاحية: استراتيجية روبنسون، استراتيجية (SQ3R)، الفهم القرائي، الصُّم،

\section{Abstract:}

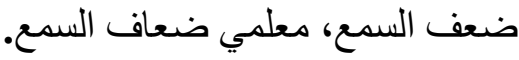

The current study aims to identify the reality of employing Robinson strategy on improving reading comprehension by hard of hearing teachers' in Jeddah, and also aims to identify their attitudes towards it. To achieve the study aims, a questionnaire consisted of (30) items was developed, and then divided into two dimensions: (a) the reality of employing the Robinson strategy by hard of hearing teachers' to improve reading comprehension, and (b) the attitudes of hard of hearing teachers' towards employing Robinson strategy, distributed over three dimensions: cognitive, behavioral, and emotional domain. The study sample consisted of (108) male and 
female teachers working in self-contained classrooms in government schools.

The results revealed that the reality of hard of hearing teachers' employment of Robinson strategy in improving hard of hearing students' reading comprehension was significantly high, as there were statistically significant differences of the reality of hard of hearing teachers' employment of Robinsons strategy in improving hard of hearing students' reading comprehension attributed to in-service training courses. The results also indicated that the degree of hard of hearing teachers' positive attitudes towards Robinson strategy was significantly high. In conclusion, the study recommended the importance of intensifying in-service training courses for hard of hearing teachers' to train them on how to employ Robinson's strategy effectively to improve reading comprehension at its different levels. Keywords: Robinson strategy, SQ3R strategy, reading comprehension, deaf, hard of hearing, hard of hearing teachers'.

المقدمة: أمر الله في أول آية أنزلها على نبينا الكريم - عليه الصلاة والسلام- بـ(اقرا)؛؛ دلالة

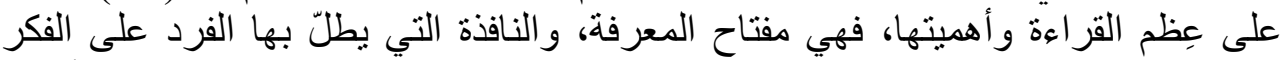
الإنساني، وبها يتزوّد بالعلوم و المعارف في مختلف المجالات، وهي الهي الرابط بين الأزمنة

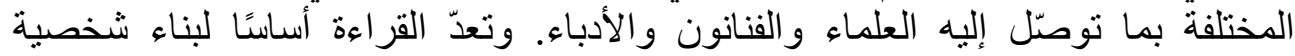
الإنسان، ومعارفه، وميوله، واتجاهاته، وبلورة منظومته القيمية، وتعميق ثقافته، ووسيلة

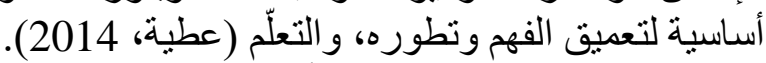
و من خلال مراجعة الأدبيات البحثية، حدّدت لجنة القراعة الوطنية الامريكية و (NRP, 2000) National Reading Panel و هي: الوعي الصوتي، والطريقة الصوتية، و المفردات اللغوية، والطلاقة، وفهر النصا.

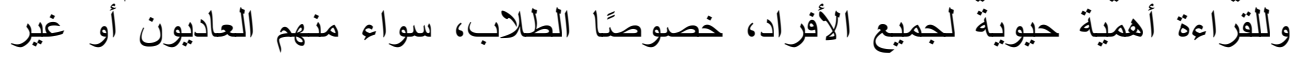

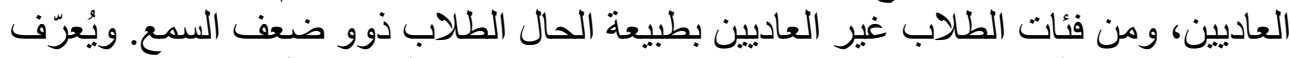
ضعيف السمع بأنه: الشخص الذي بعاني من فقدان سمعي في أفضل الأذنين بمقدار يتراوح

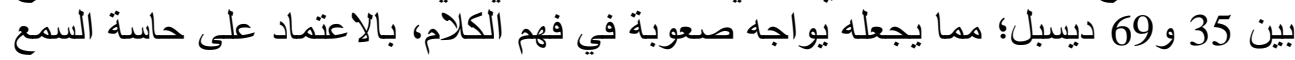


فقط، بعد استخدام المُعينات السمعية (الدليل التنظيمي للتربية الخاصة، 1436- 1437، ص.9).

وكثفت نتائج المسح التي قامت بها الهيئة العامة للإحصاء في المملكة العربية

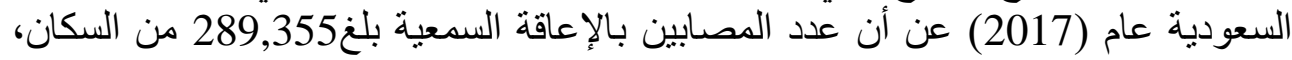

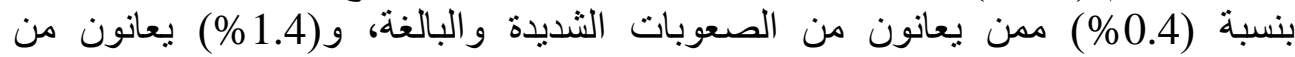
صعوبات خفيفة ومتوسطة وشنديدة.

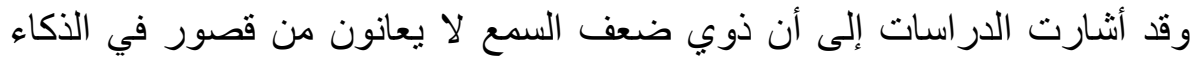

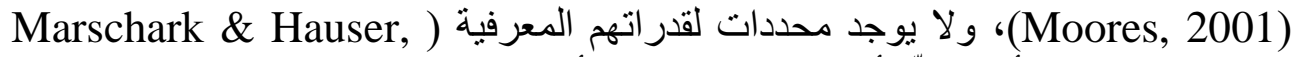
2008)، و 2006

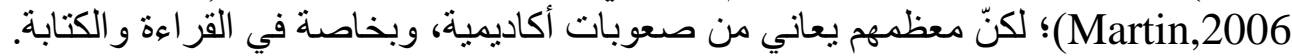

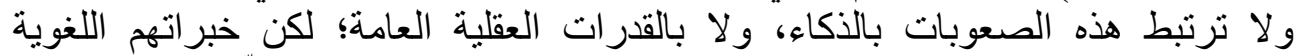

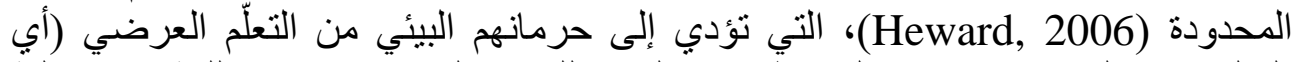

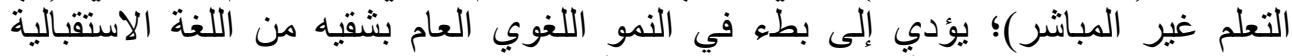

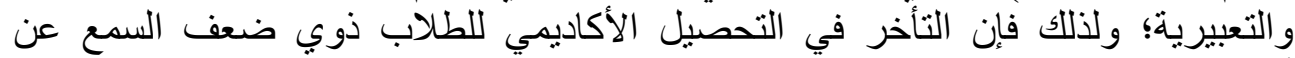

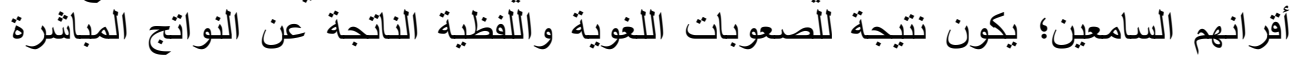

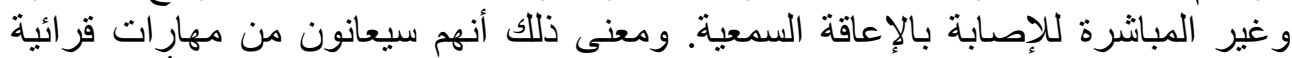

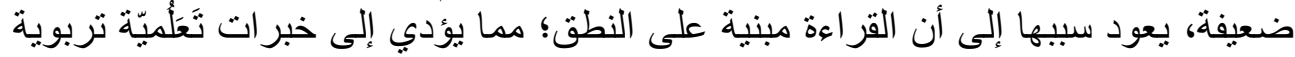

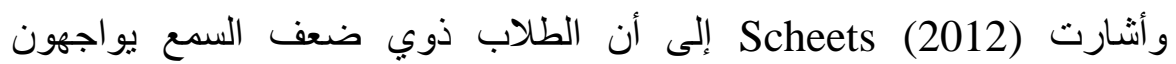
محدودة.

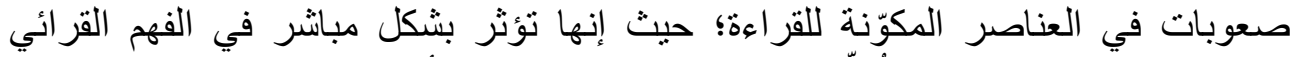

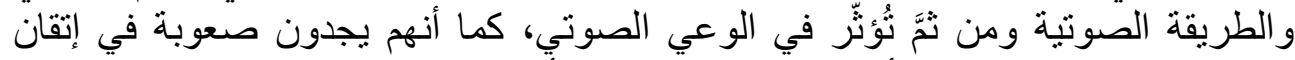

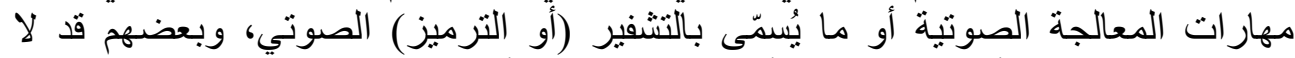

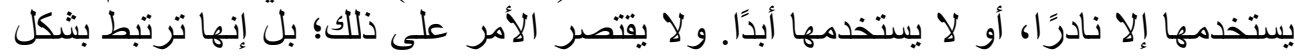

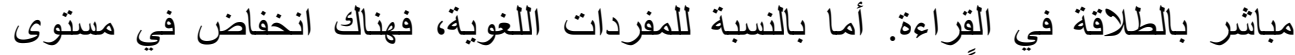

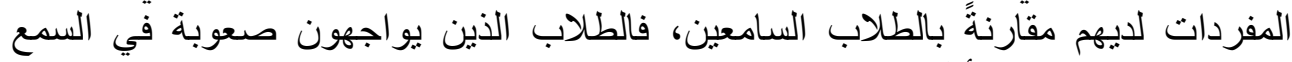

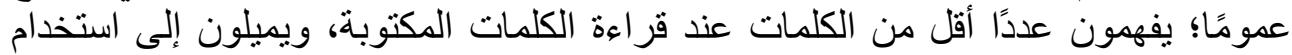

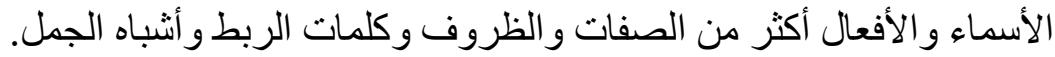

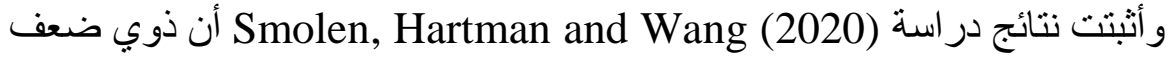

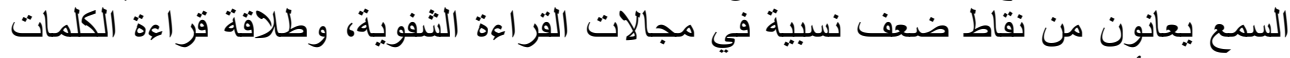

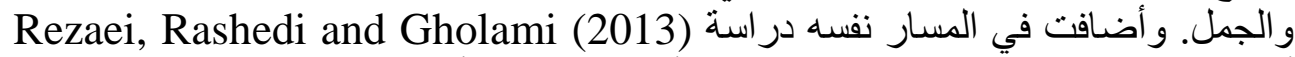

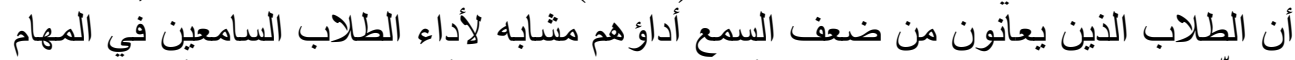

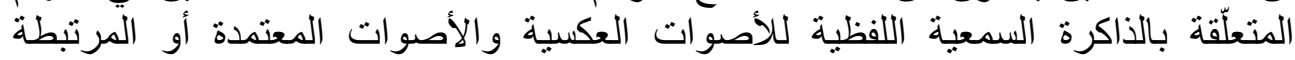




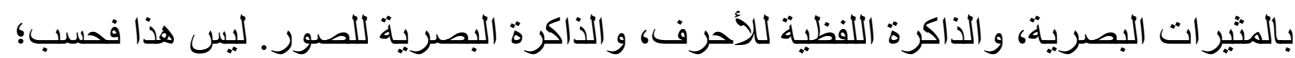

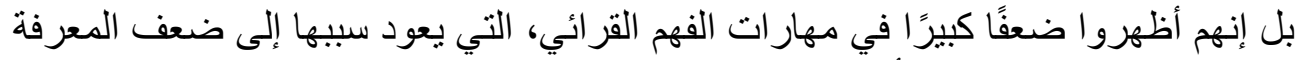

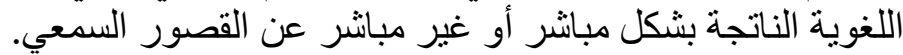

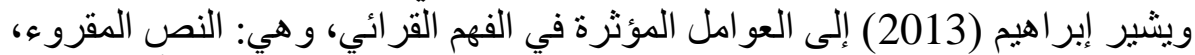

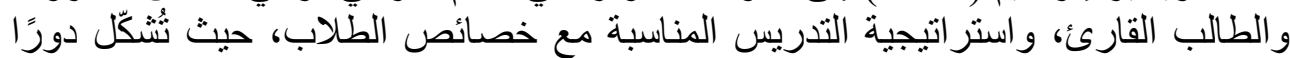

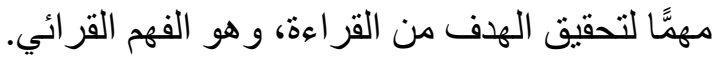

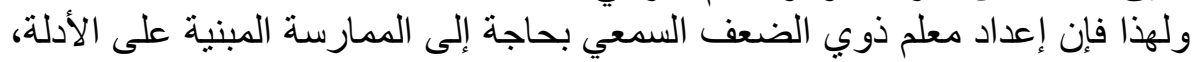

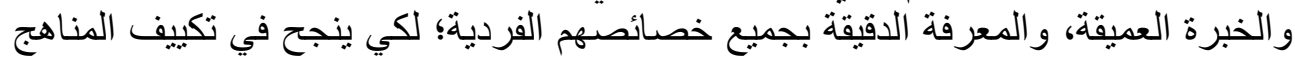

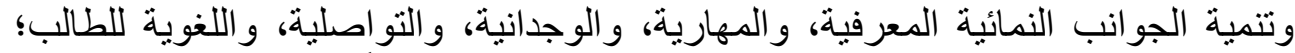

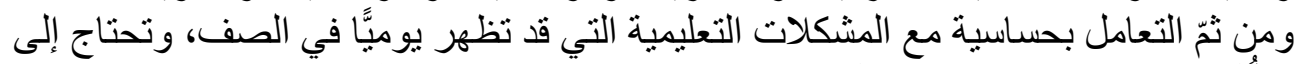

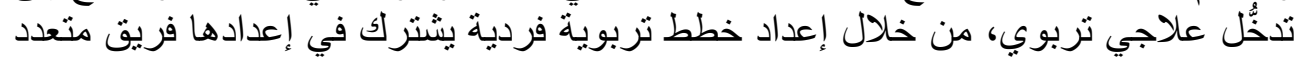

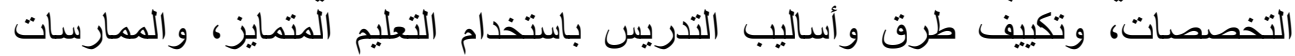

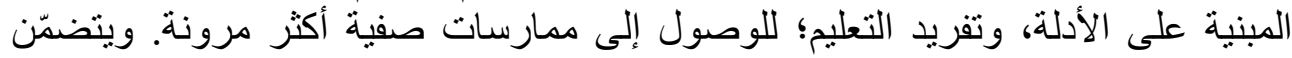

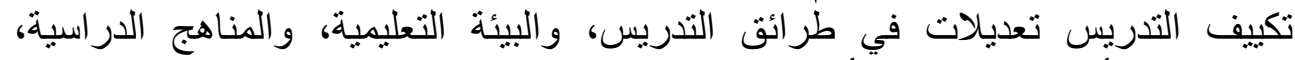

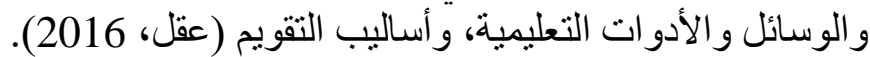

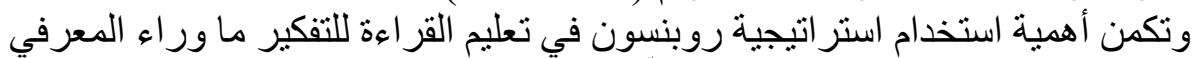

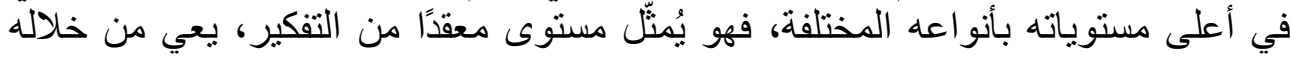

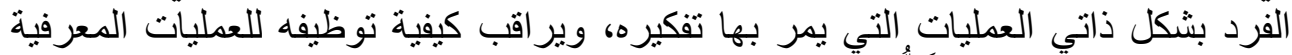

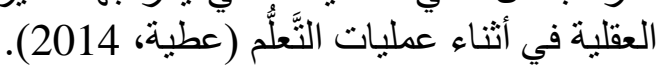

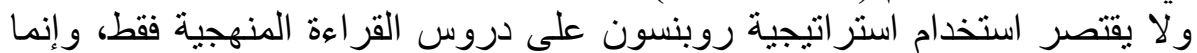

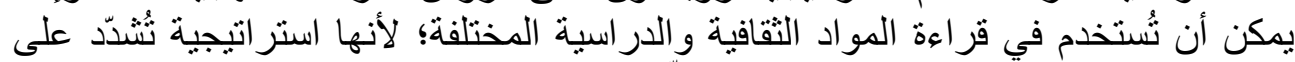

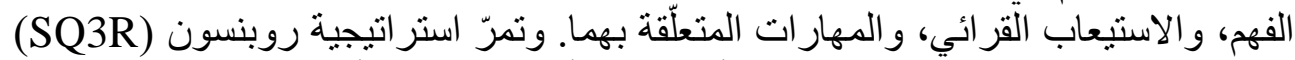

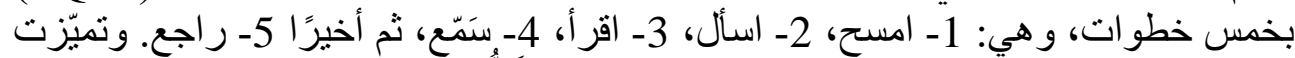

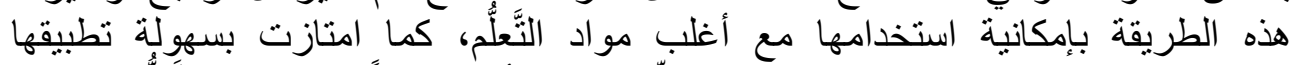

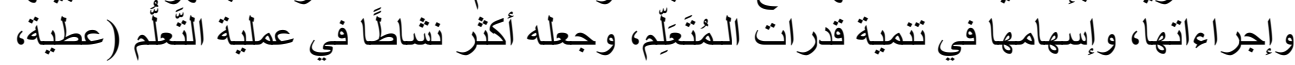
. (2014

و أسفرت نتائج در اسة الرشيد و الدوسري (2020) عن ارتفاع مستوى إحدى الطالبات

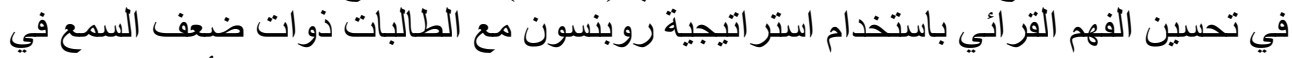

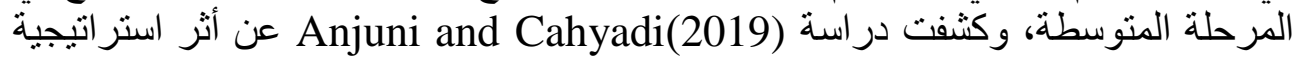

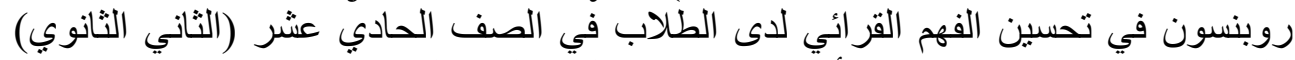

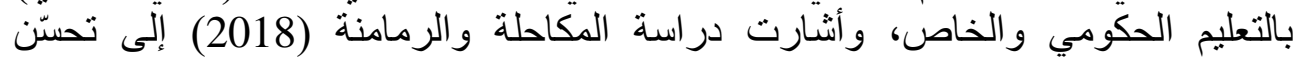


مهار ات الفهم القر ائي باستخدام استر اتيجية روبنسون لدى الطلاب ذوي صعوبات التَّلُُم في عمان. مشكلة الار اسة

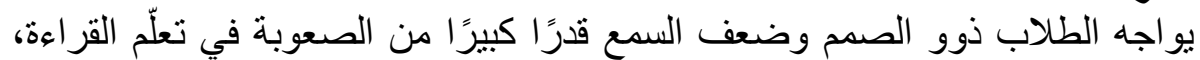

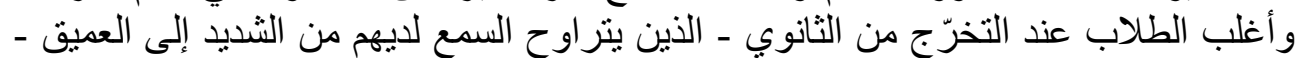

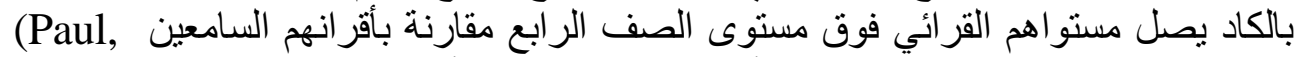

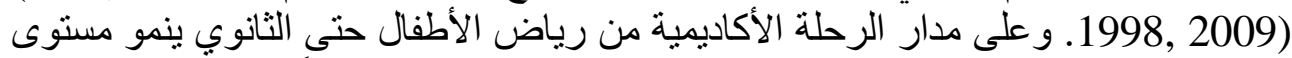

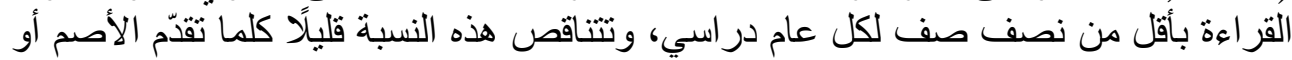

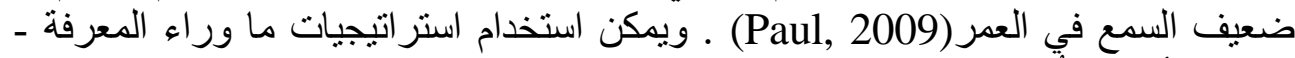

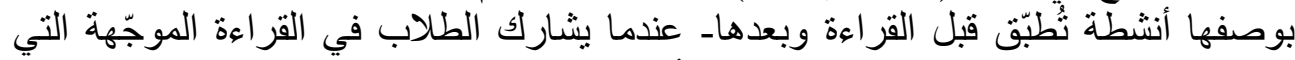

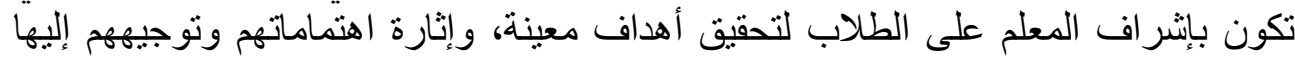

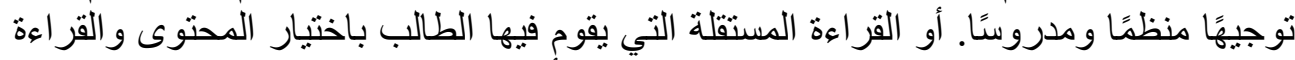

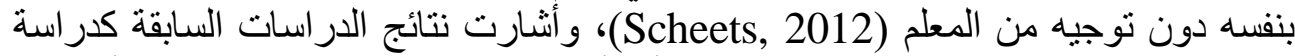

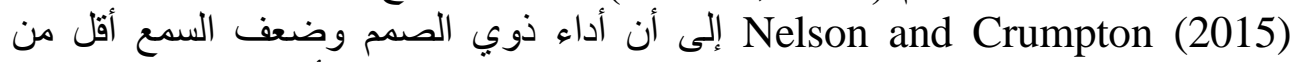

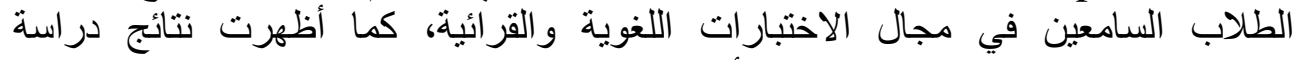

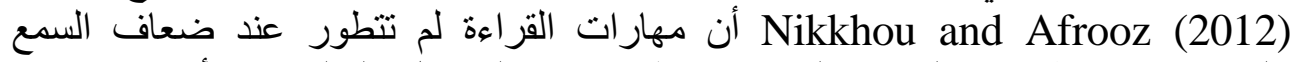

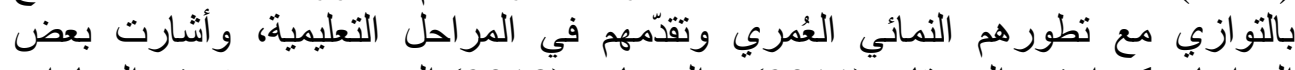

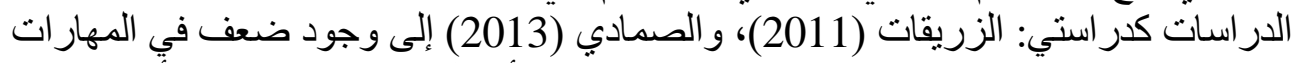

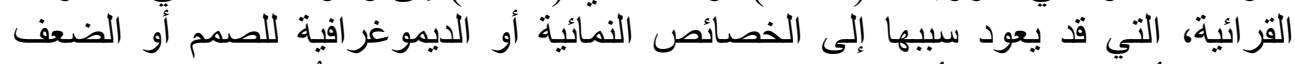

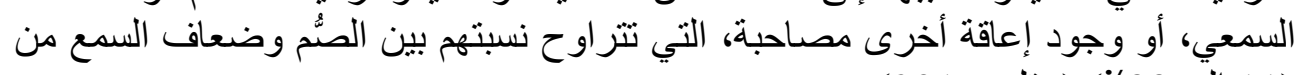
(11 إلى 33\%) (عقل، 2016).

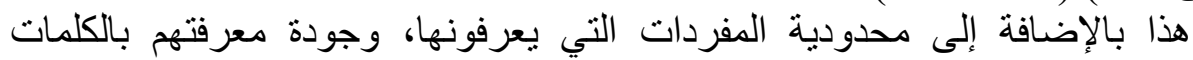

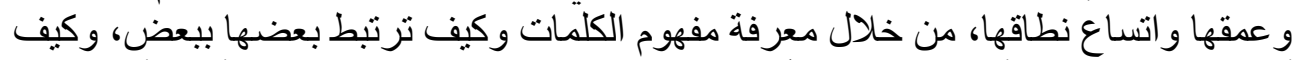

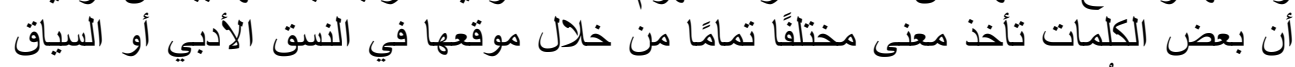

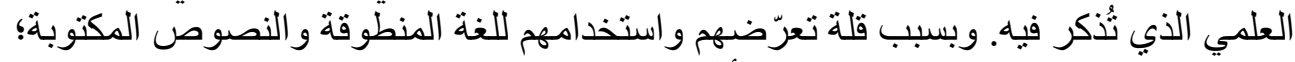
فnoors \& ) فإن قدراتهم على فهم المعاني تكون أقل بكثير من نظر ائهم السامعين

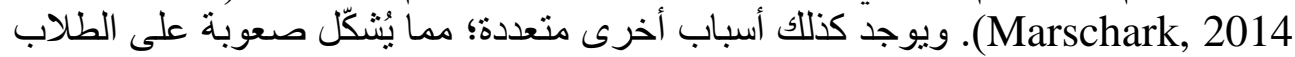

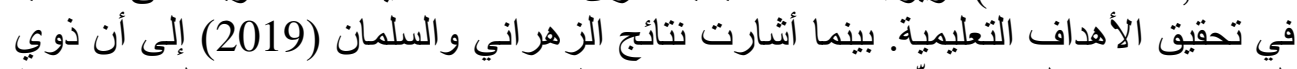

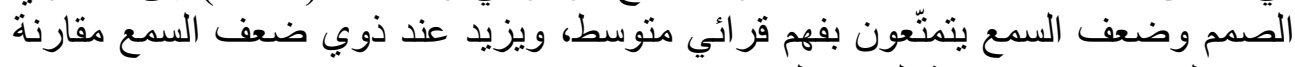
بذوي الصمم بحسب درجة الفقدان السمعي.

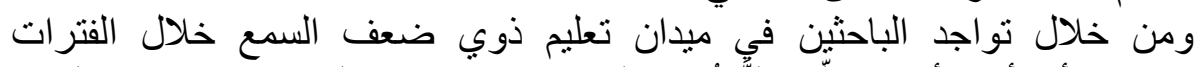

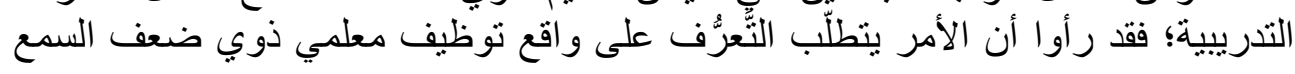


لاستر اتيجية روبنسون في تحسين الفهم القرائي ومعرفة اتجاهاتهم نحوها؛ لمعرفة أثر هذه وذهي

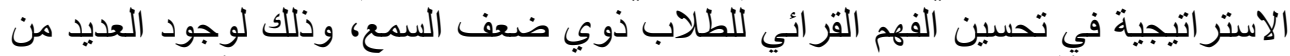

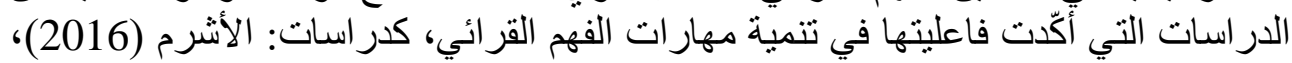

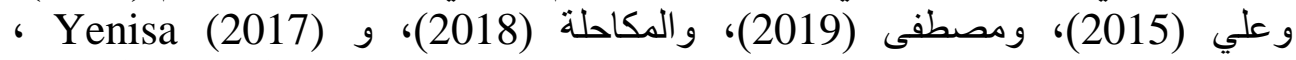

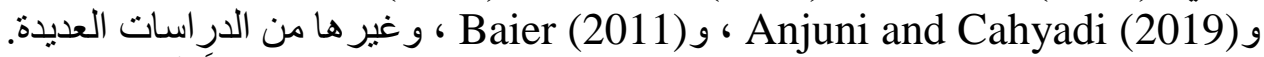

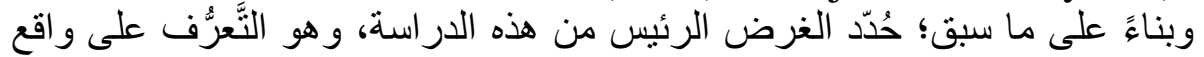

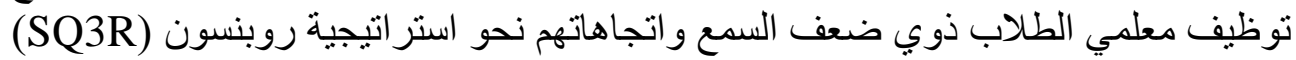
لتحسين الفهم القر ائي لدى طلبنهم. أسئلة الدراسية المانة 1- ما و اقع توظيف استر اتيجية روبنسون لتحسين الفهم القر ائي من قِبل معلمي الطلاب ذوي

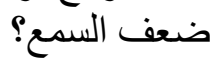

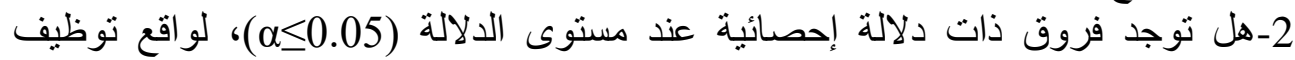

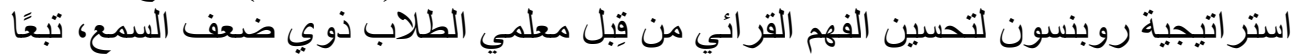

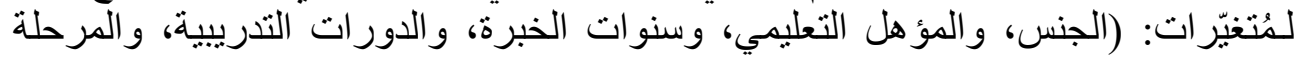
التعليمية) 3- ما اتجاهات معلمي الطلاب ذوي ضعف السمع نحو توظيف استراتيجية روبنسون لتحسين القهم القرائي؟ ماتي

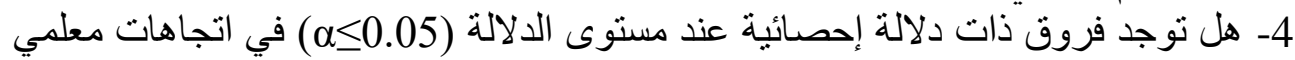

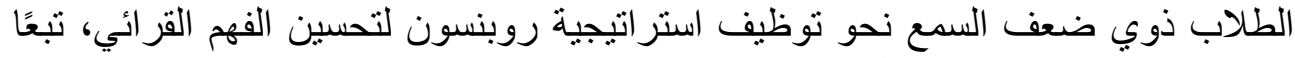

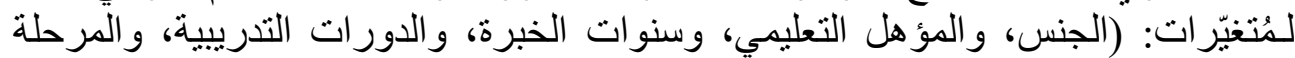
التعليمية) ؟ أهداف الدراسـة سعت الدر اسة الحالية إلى التّرّرف على الأهداف الآتية:

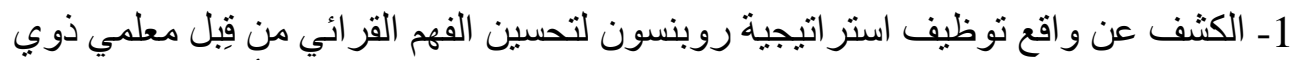

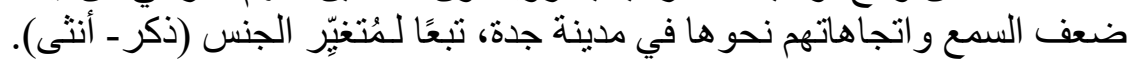

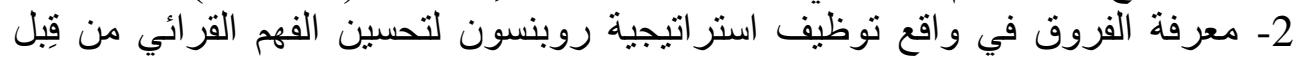

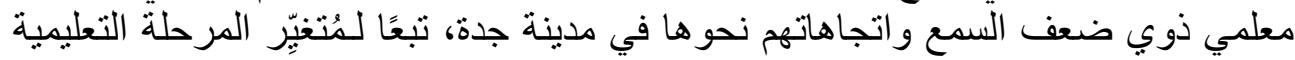

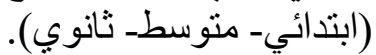

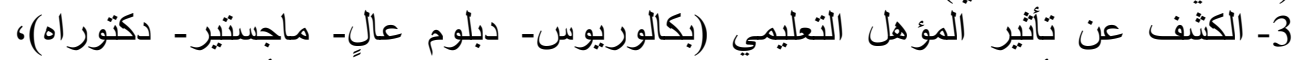

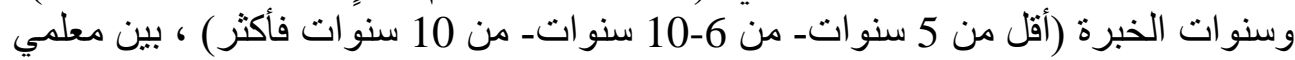

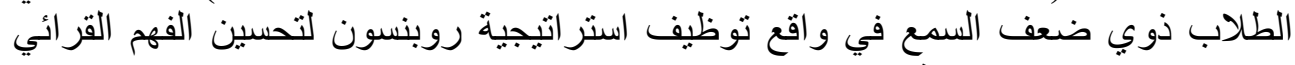
واتجاهاتهم نحو ها في مدينة جدة. 
4ـ التَّعرُّف على الفروق في واقع توظيف استر اتيجية روبنسن لتحسين الفهم القر ائي من قِبِل

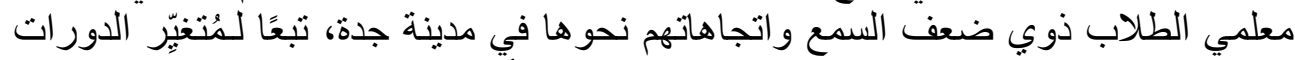

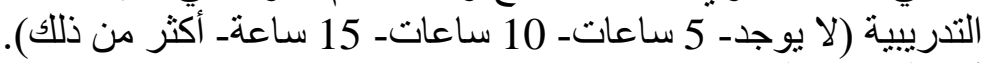
أهمية الدراسة (لاسة تكمن أهمية الدر اسة ـكما ير الها الباحثين- في الآتي: أولًا - الأهمية النظرية النية النية

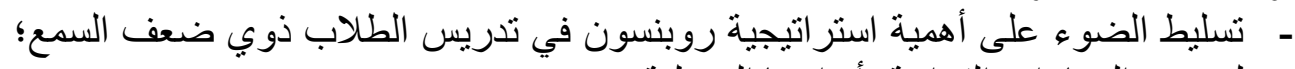

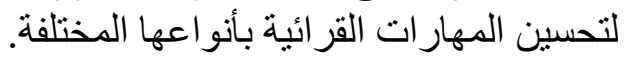

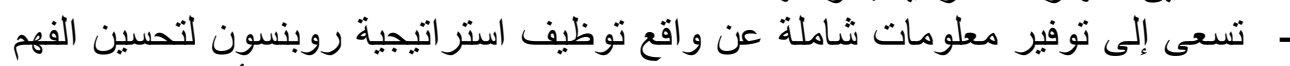

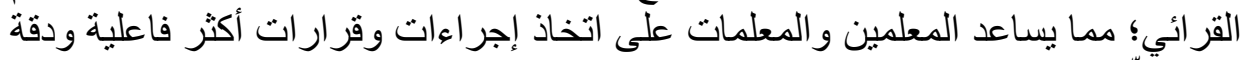

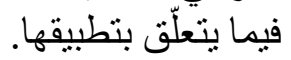

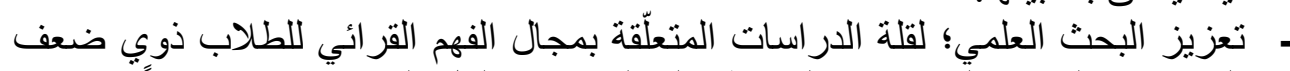

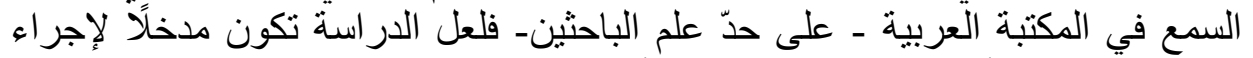

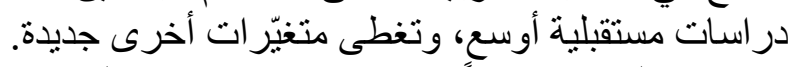

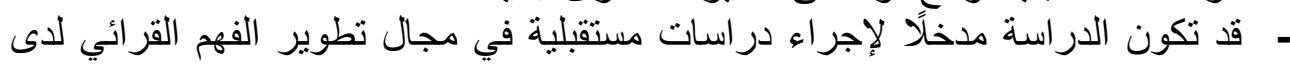

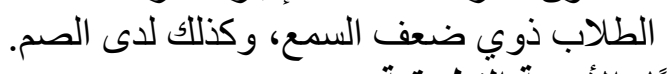
ثانيًا- الأهمية التطبيقية التبية

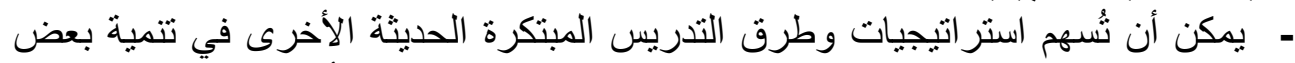

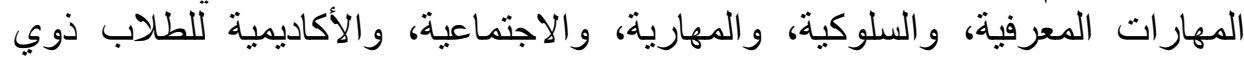

- قد تُعهم الدراسة في الوصول إلى بعض التوصيات في تحسين اتجاهات معلمي الطلاب ذوي ضعف السمع نحو توظيف استر اتيجية روبنسون؛ لتحني التحسين الفهم القرائي.

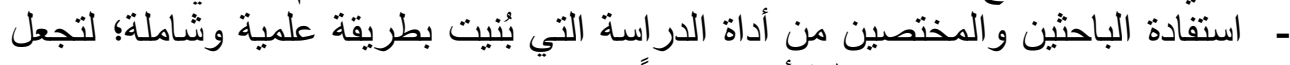

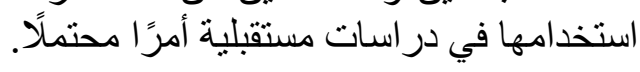

$$
\text { حدود الدراسـة الخداف }
$$

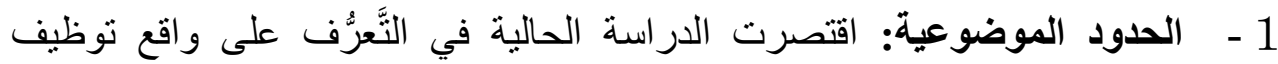

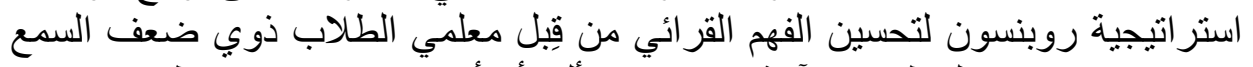

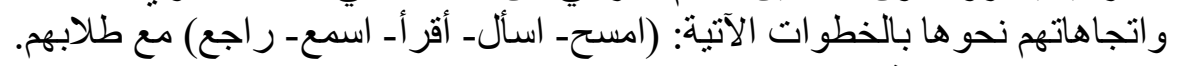

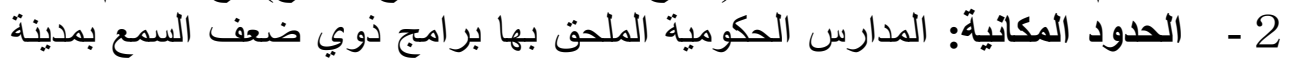
3 - الحدود الزمانية: جُمعت البيانات لهذه الدراسة في الفصل الدراسي الثاني لعام 2020م-2021 2021 
4 - الحدود البشرية: اقتصر تطبيق هذه الدراسة على معلمي ومعلمات الطلاب ذوي

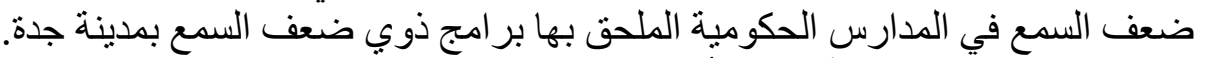

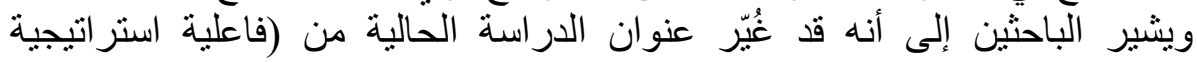

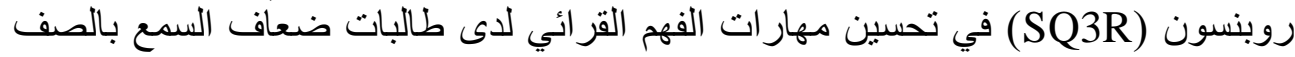

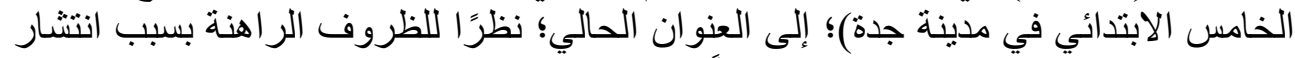

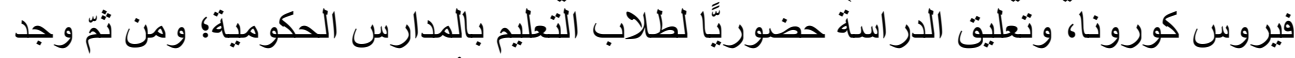

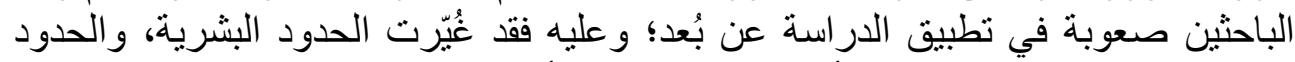

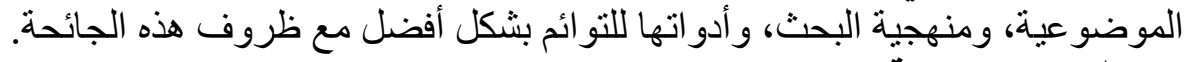

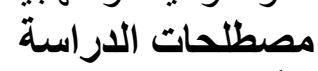

أولًا استراتيجية روبنسون (Robinson)

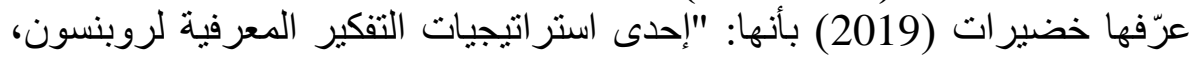

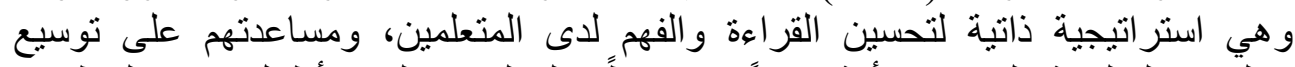

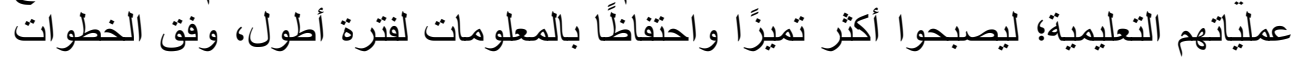

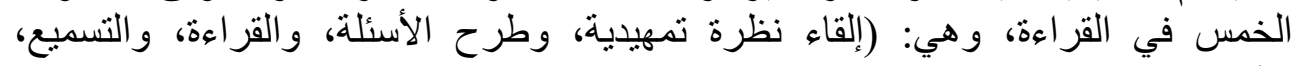

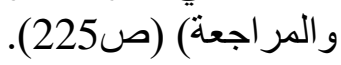

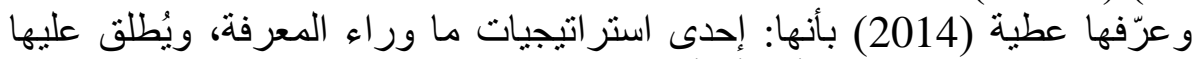

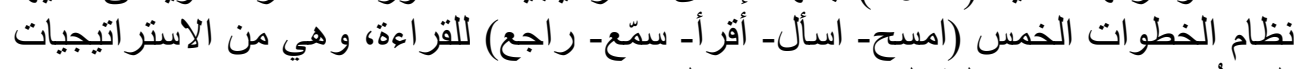

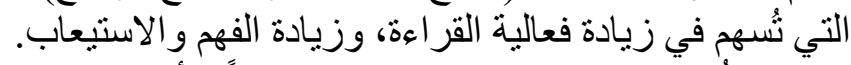

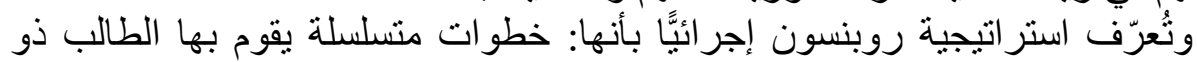

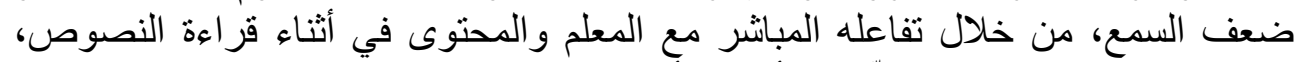

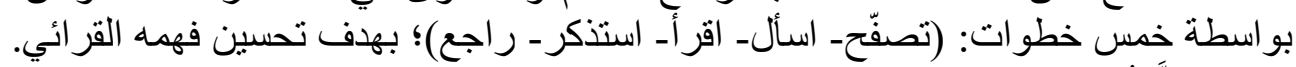

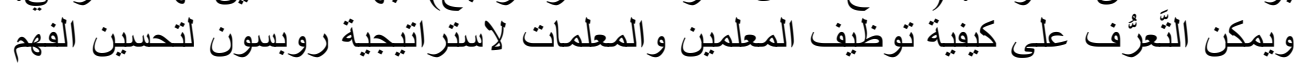

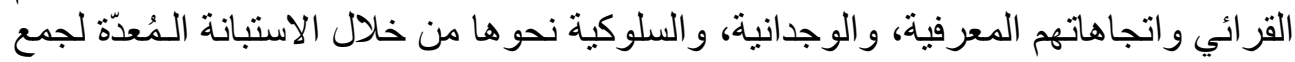
البيانات في الدر استة الحالية.

ثانيًاً الفهم القرائي (Reading Comprehension)

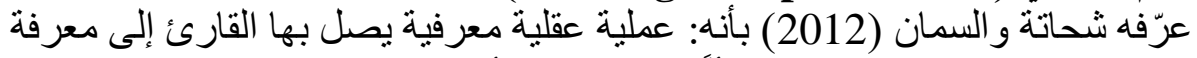

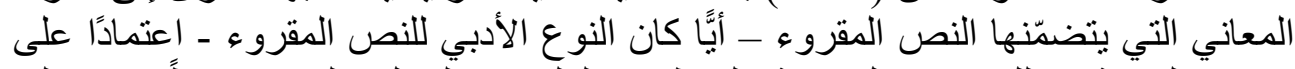

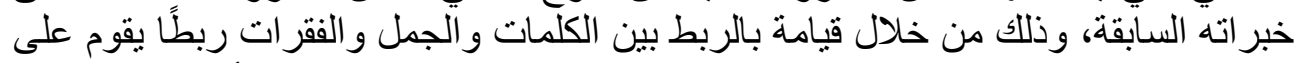

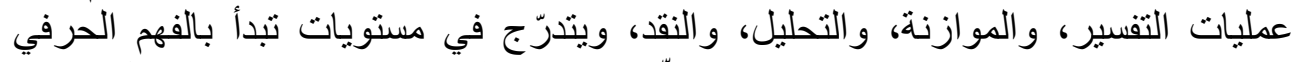

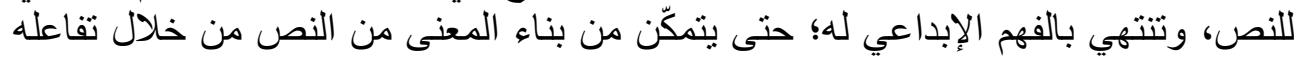




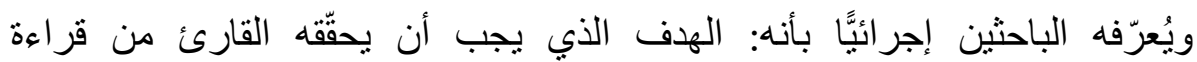

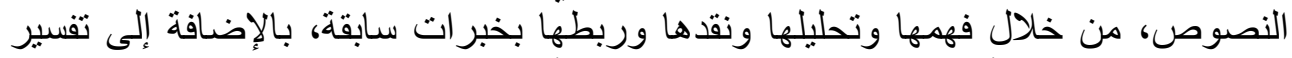

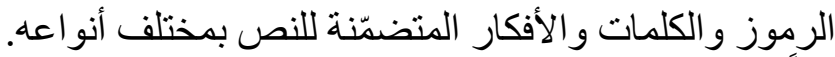

ثالثًا ضعاف السمع (Hard of Hearing)

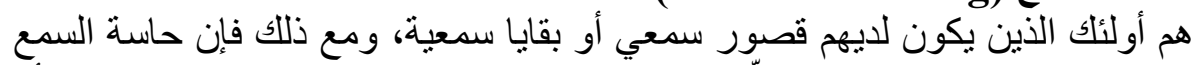

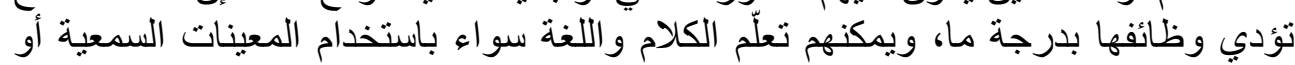

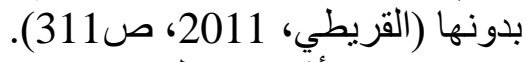
و هم الأشخاص الذين يعانون من فقدان سمعي يتراوح مان ما بين 35 و و69 ديسبل، بعد

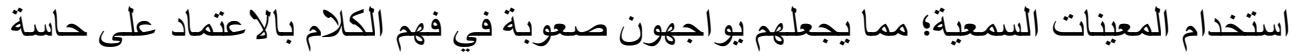
السمع فقط (Moores,2008). وقد تبنّ الباحثين هذا التعريف للعالم الكبير دونالد موريس. يوجد لضعف السمع عده تعريفات اختلفت في الصياغة، واشتركت في المعنى، وهي

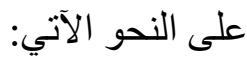

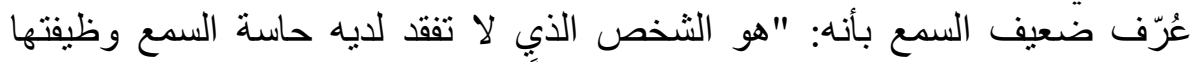

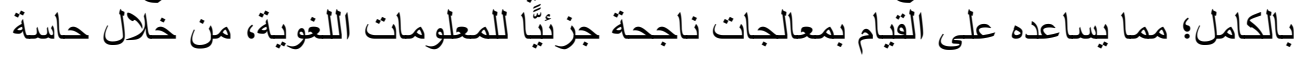

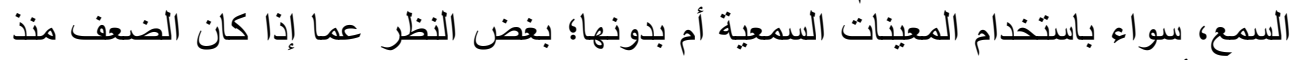

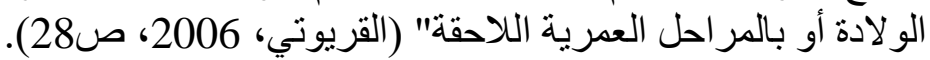

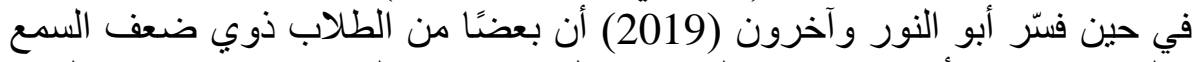

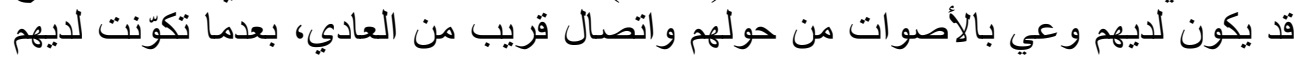

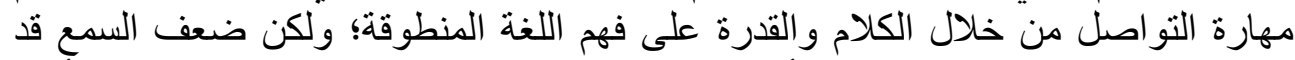

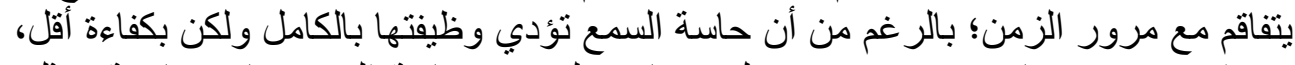

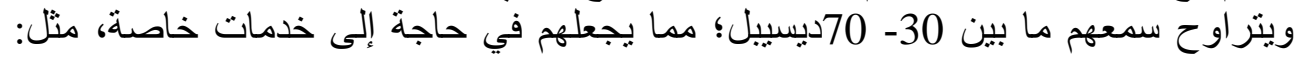

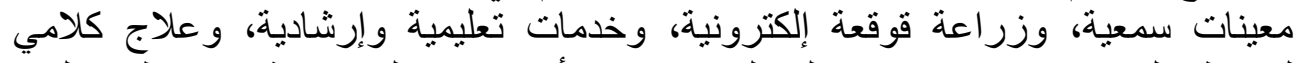

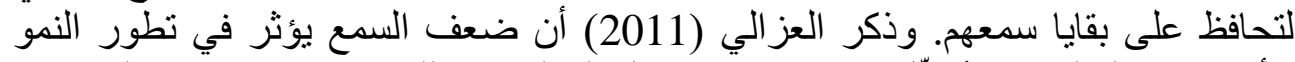

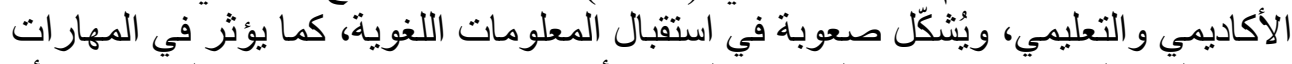

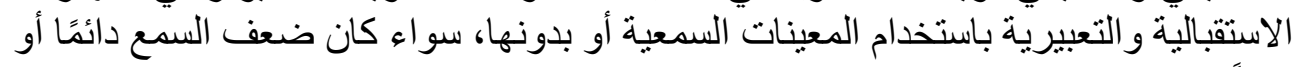
مؤقتًا.

و ورّّف الجوالدة (2012) مصطلح ضعف السمع بأنه: "درجة من فقدان السمع تزيد

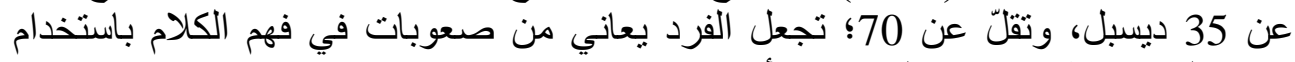

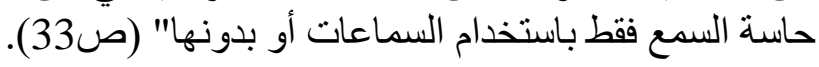


التحصيل الأكاديمي لذوي ضعف السمع

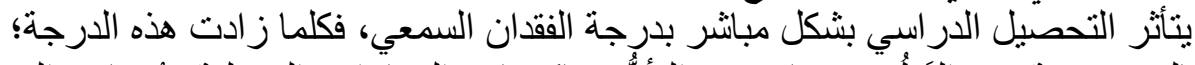

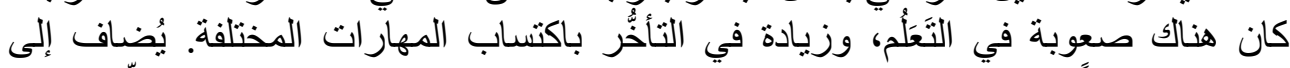

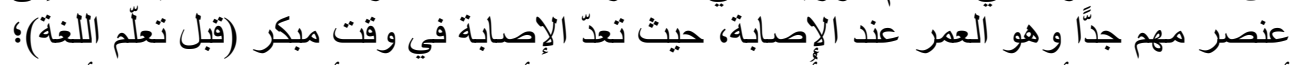

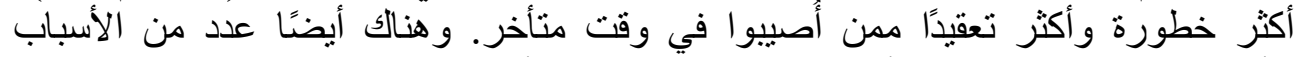

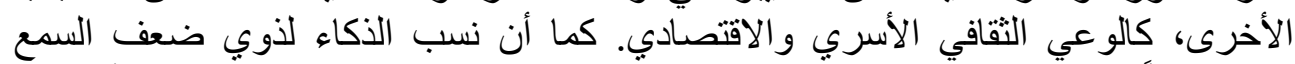

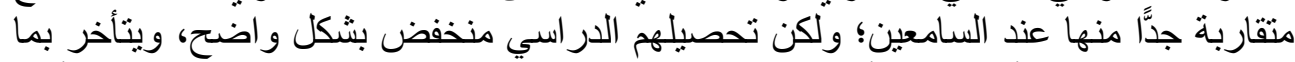

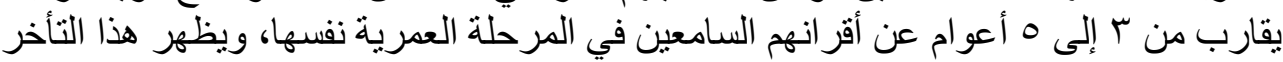

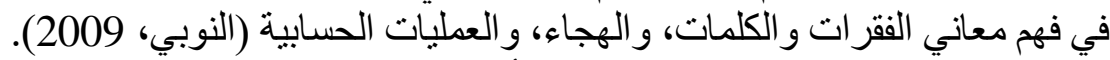

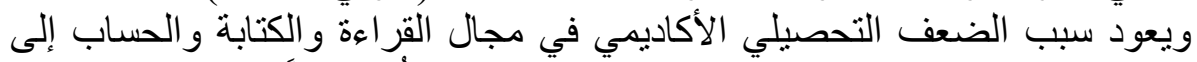

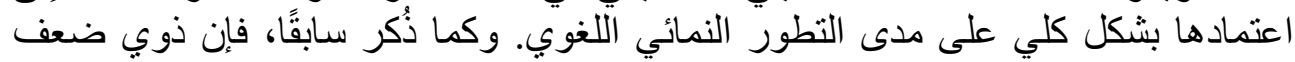

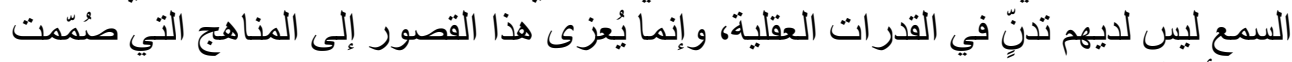

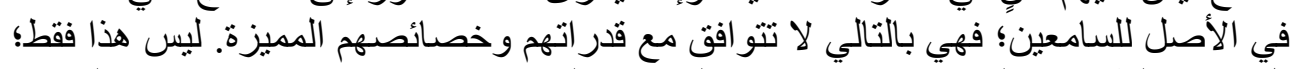

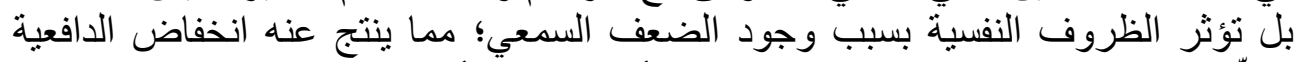

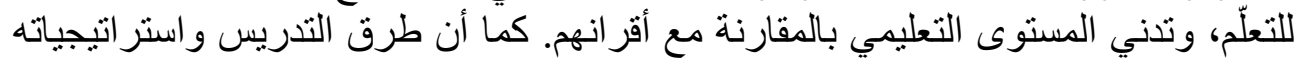

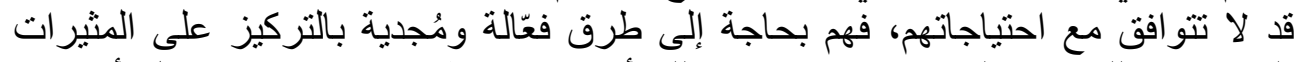

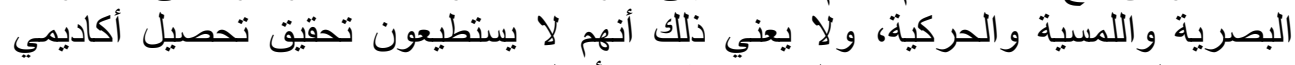

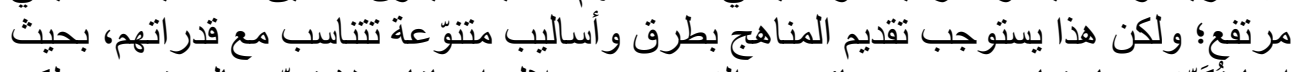

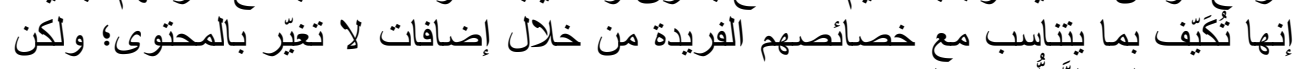

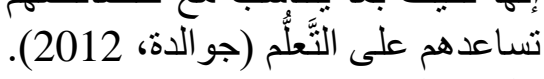

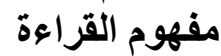

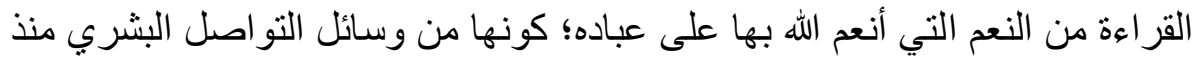

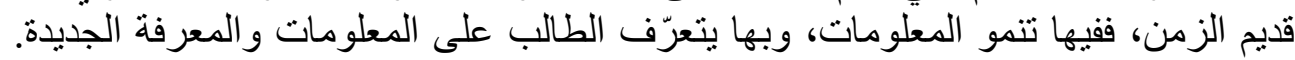

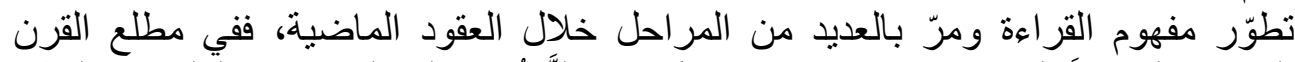

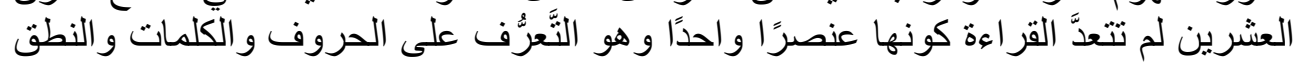

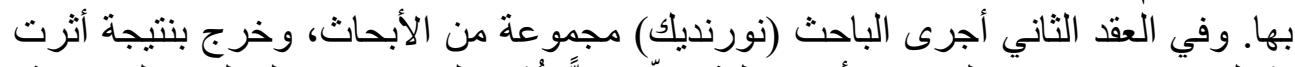

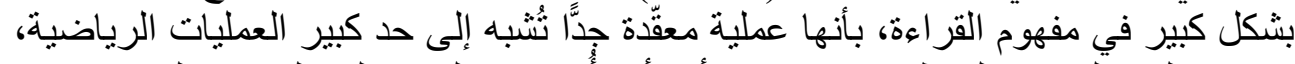

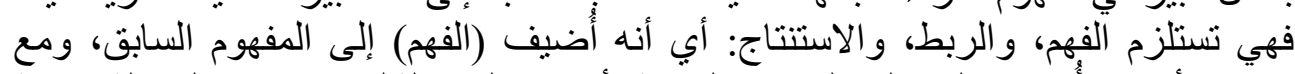

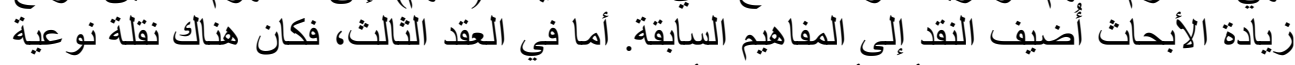

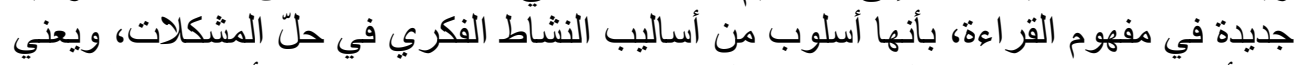

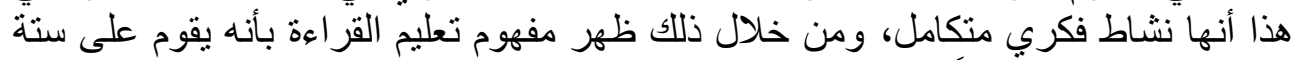

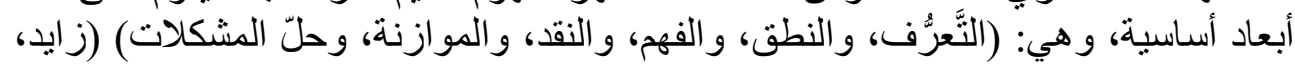




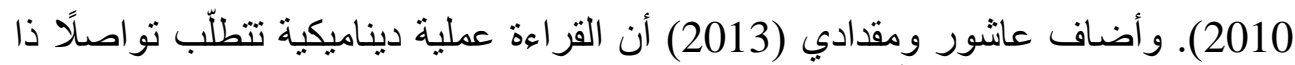

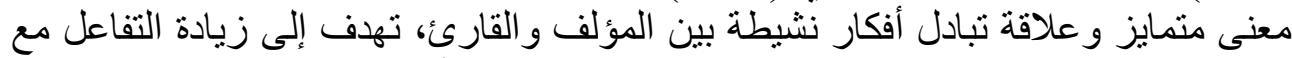

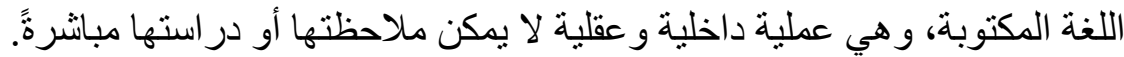

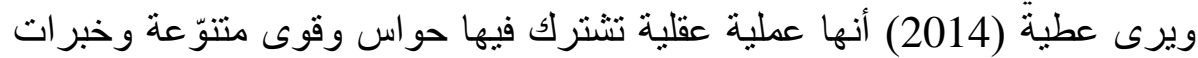

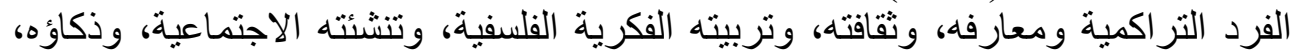

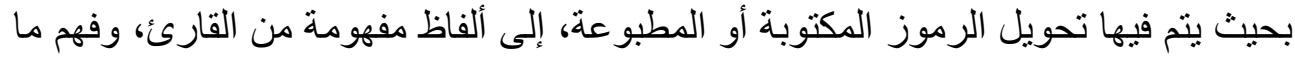

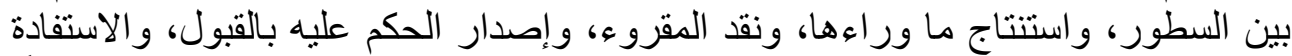

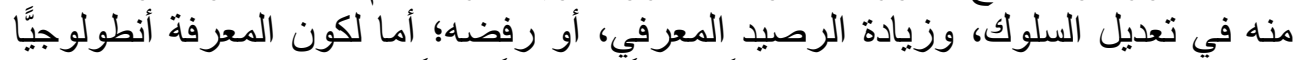

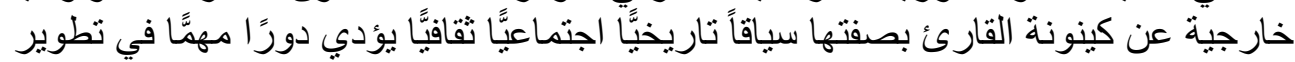

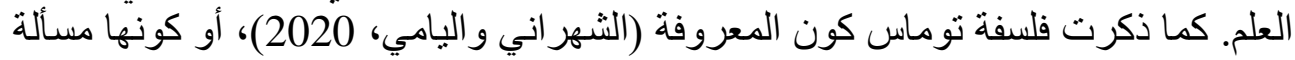

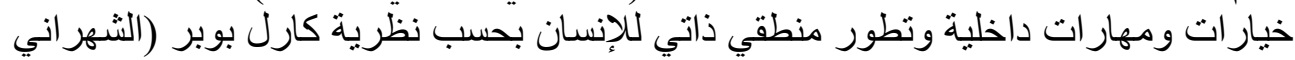
مكوّناتي، القراعة 2020). عملية القر اعة عملية صعبة ومعقّة، وتعتمد على مجموعة كبيرة جدًَا من المهارات

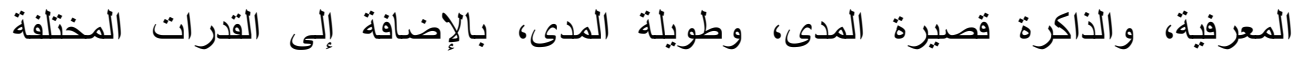

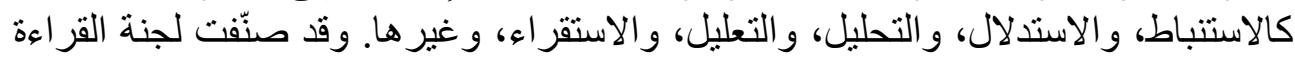

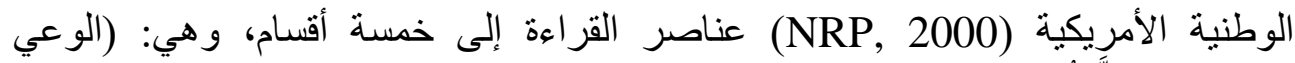

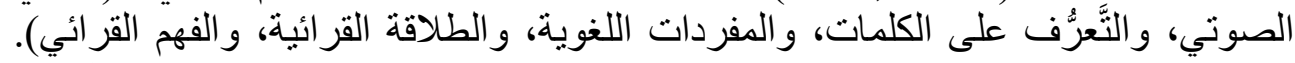

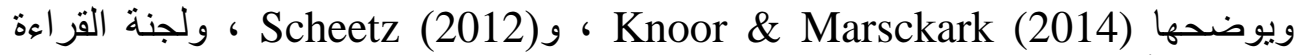
الوطنية الأمريكية (NRP, 2000) كالآتي: 1- 1 الوعي الصوتي الاني

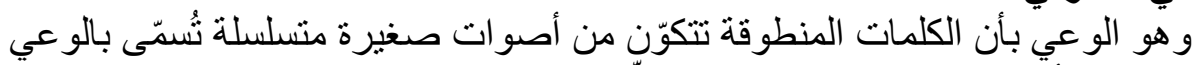

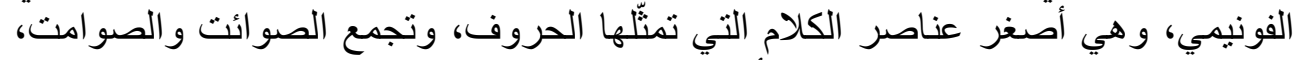

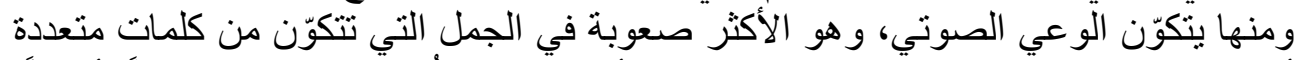

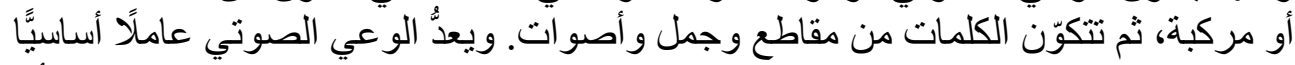

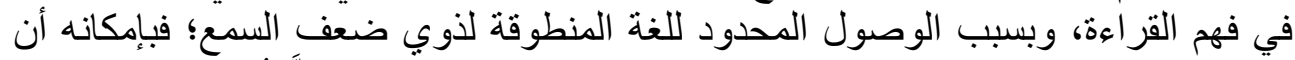

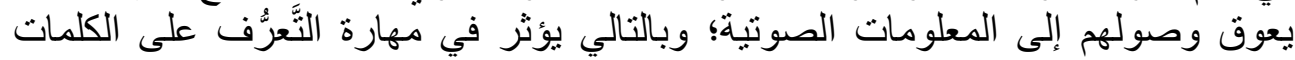

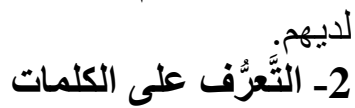

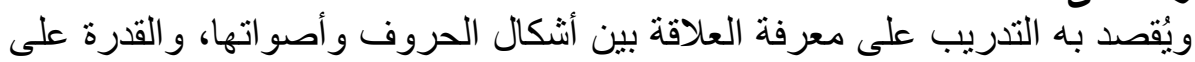

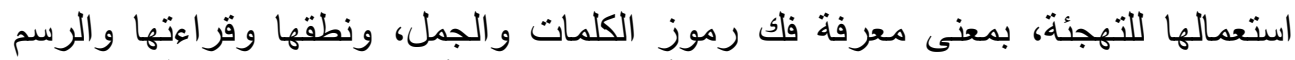

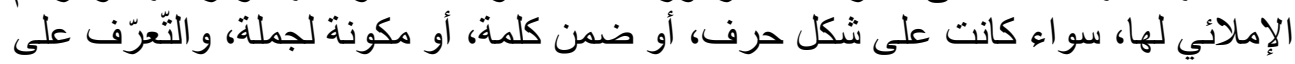




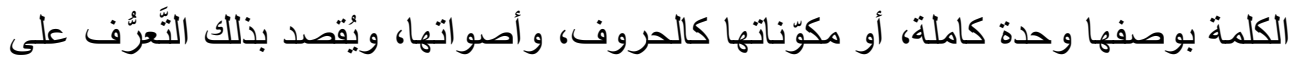

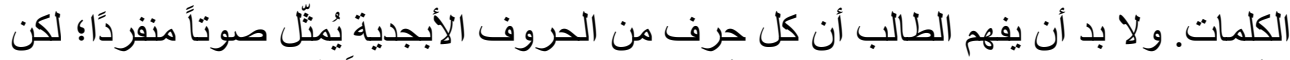

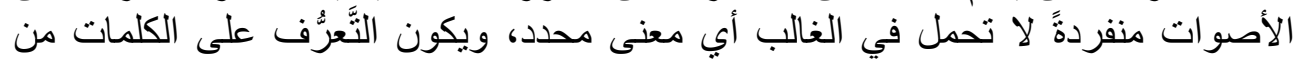

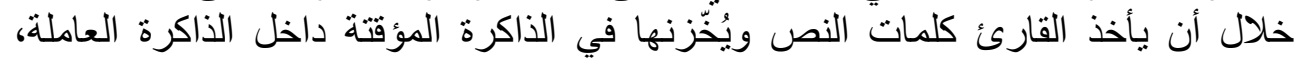

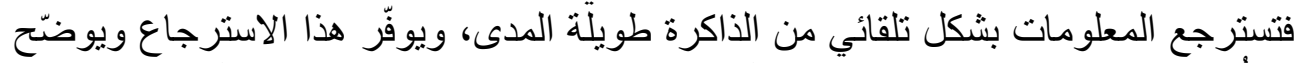

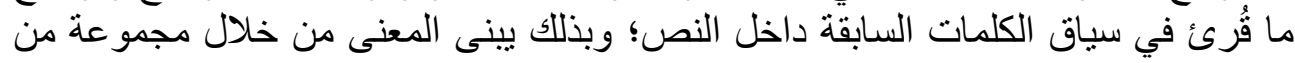

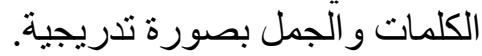

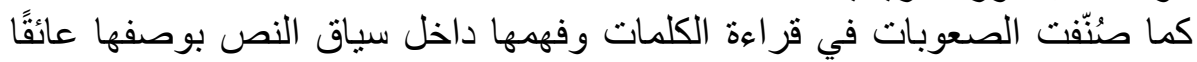

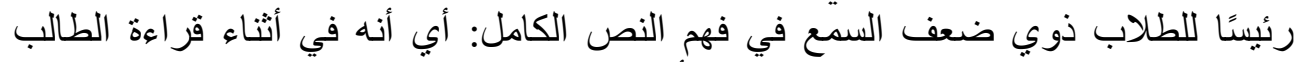

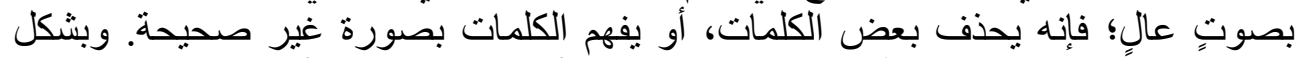

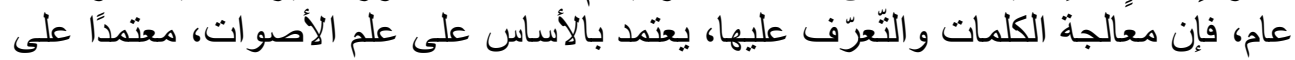

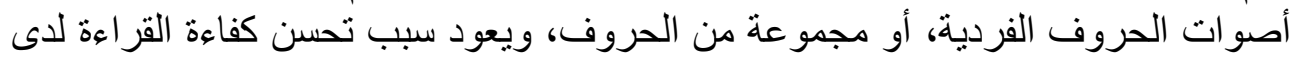

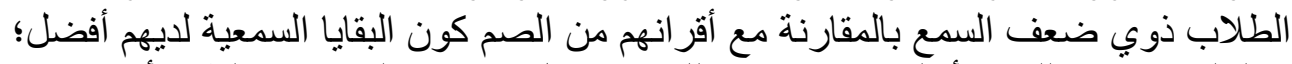

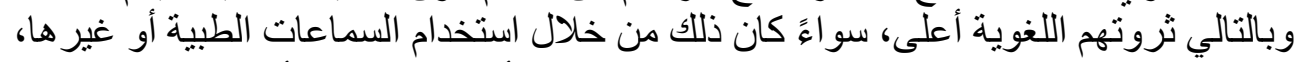

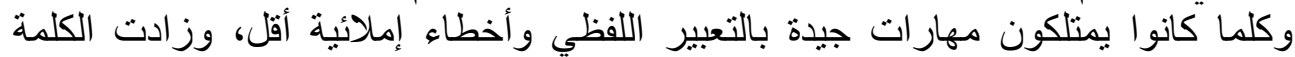

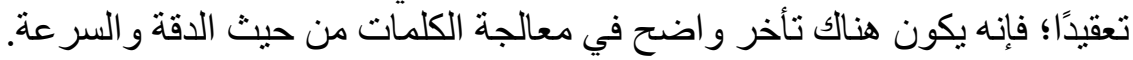
3- المفردات اللغوية

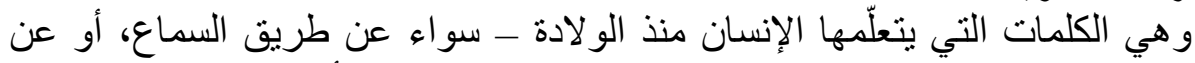

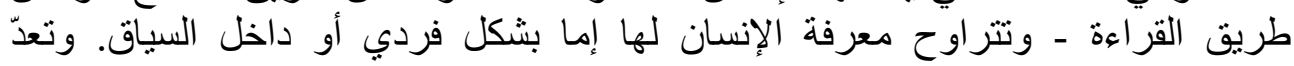

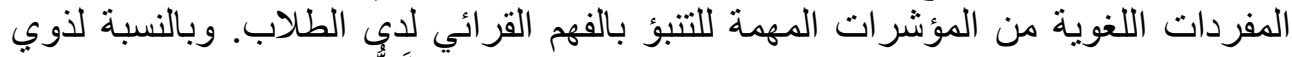

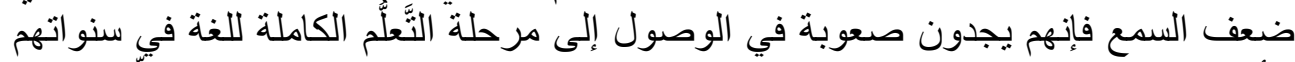

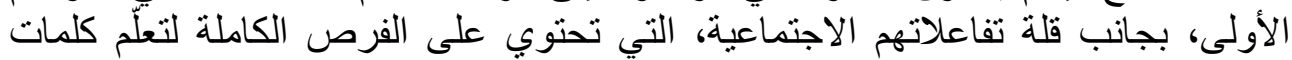

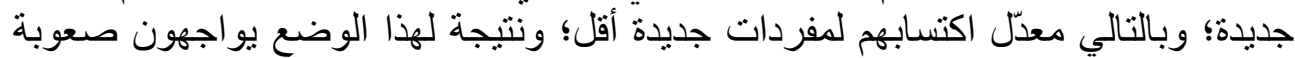

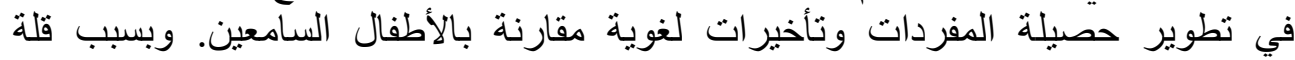

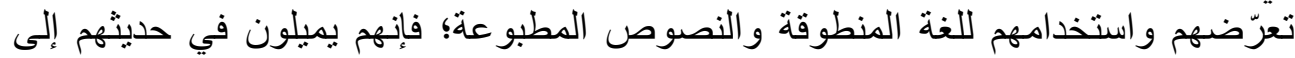

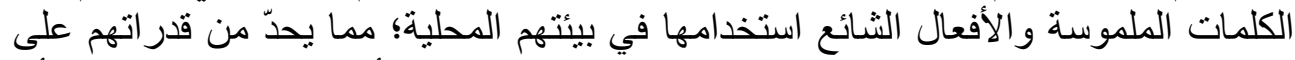

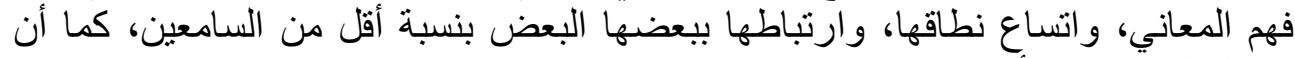

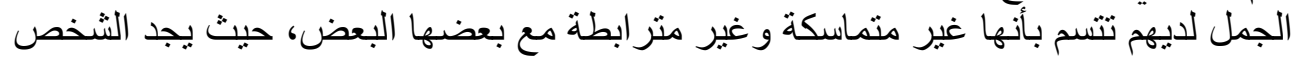

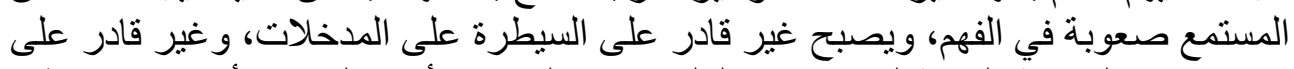

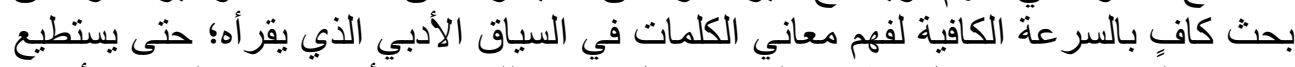

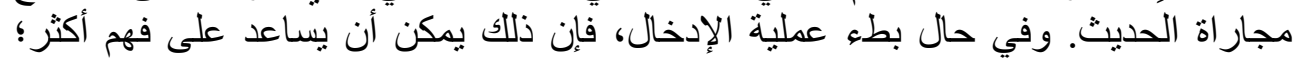


ولكن سيتم التركيز على المفردات أكثر من فهم الرسالة بالكامل، وفي الحالتين فإن النتيجة فهم لغوي ضعيف و غير مُجدٍا. 4- الطلاقة القرائية

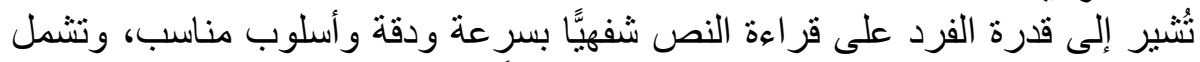

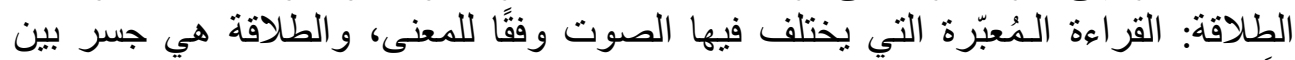

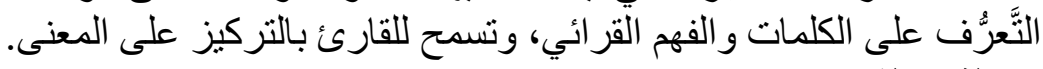
5- الفهم القرائي

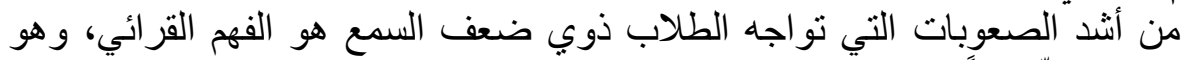

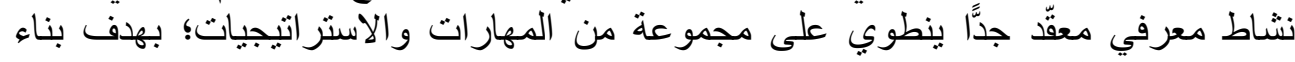

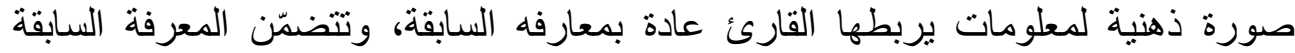

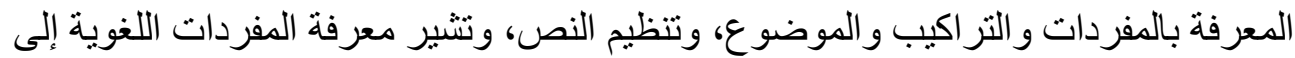
مؤشر قوي للفهم القرائي.

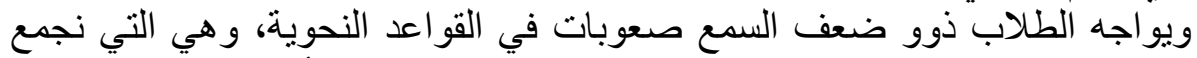

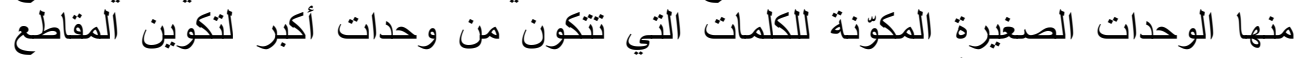

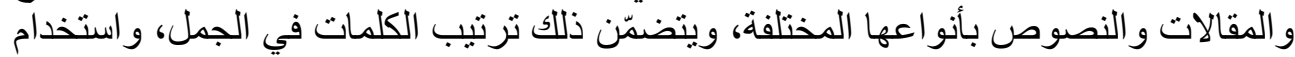

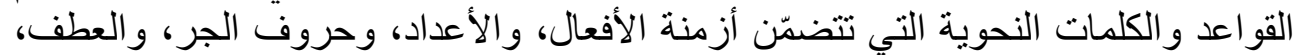

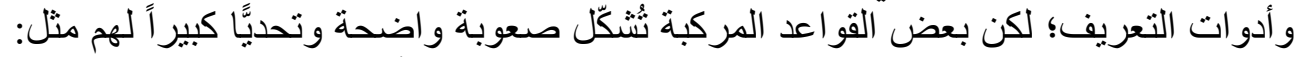

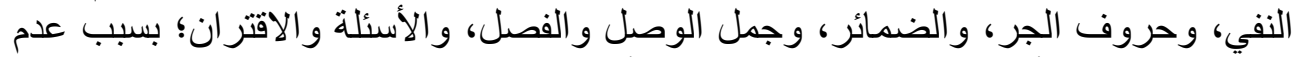

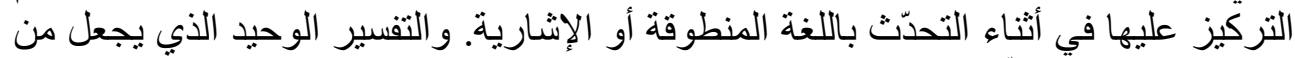

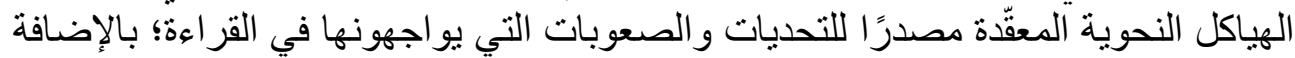

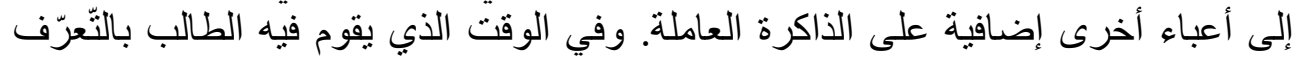

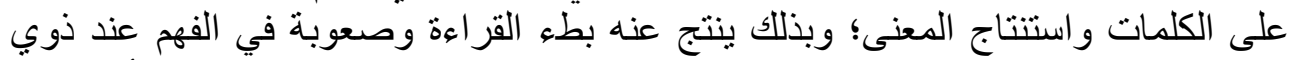

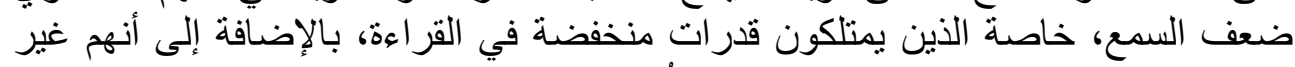

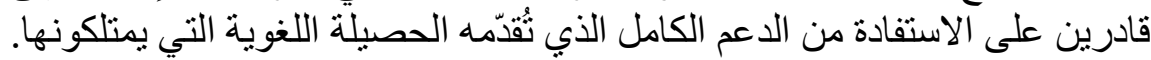

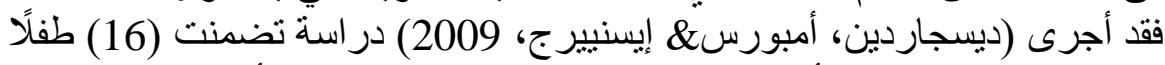

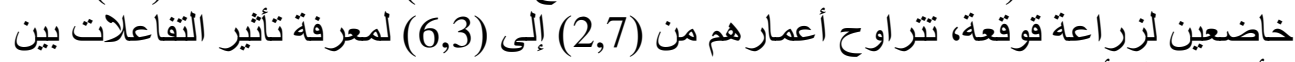

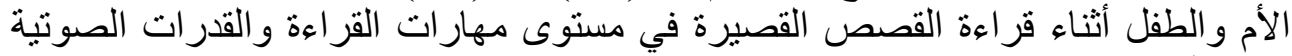

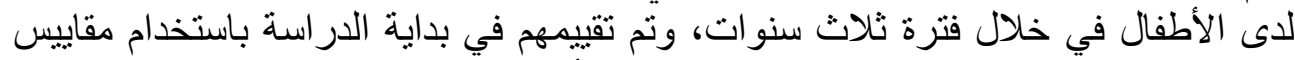

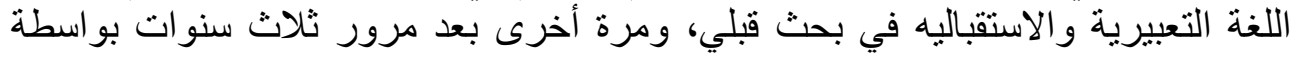

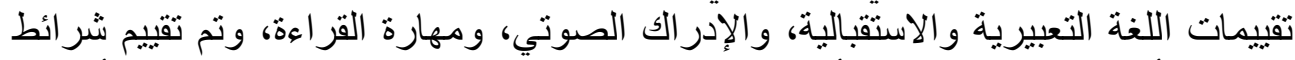

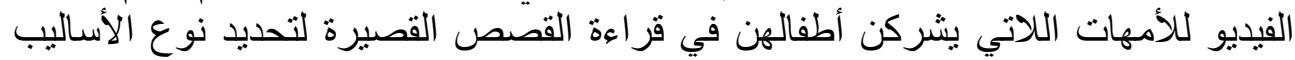
الميسرة المستخدمة في ذللك. 


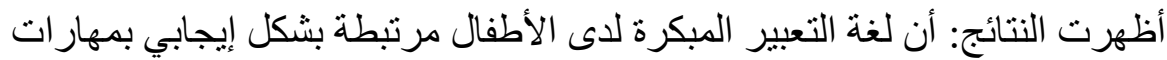

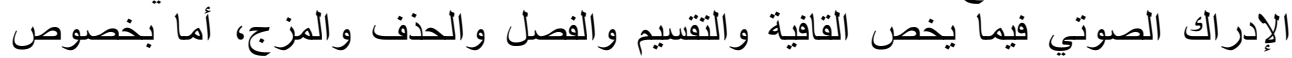

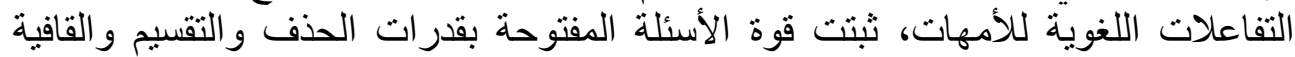

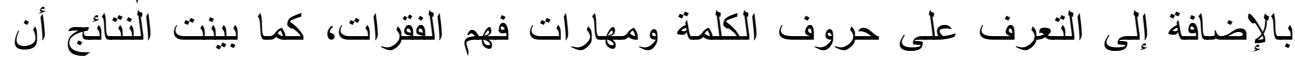

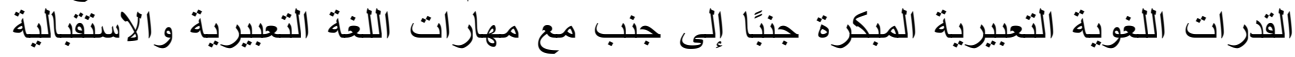

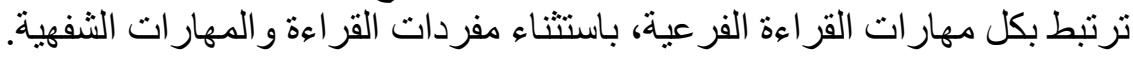

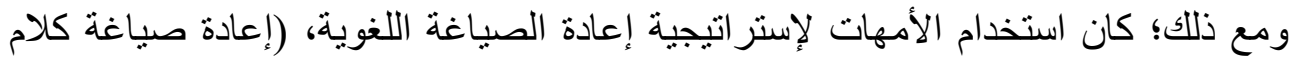

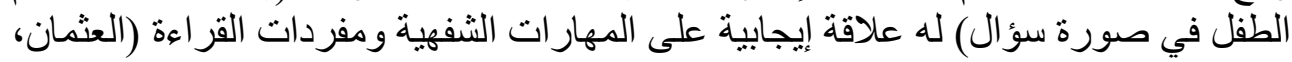

الفهم ألقرائي عملية معقّة، ويعتمد بشكل مباثر على الخلفية اللغوية للطالب، وقدرته

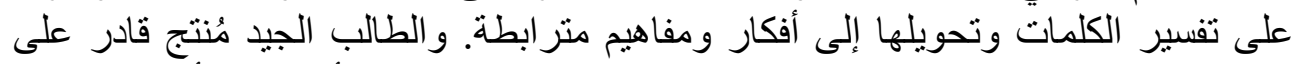

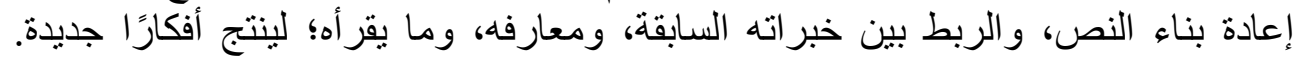

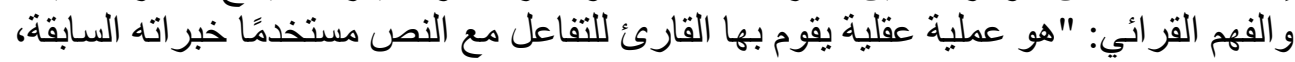

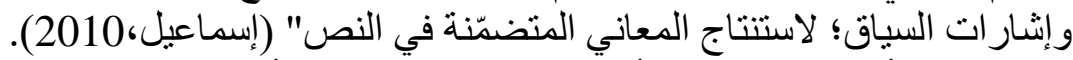

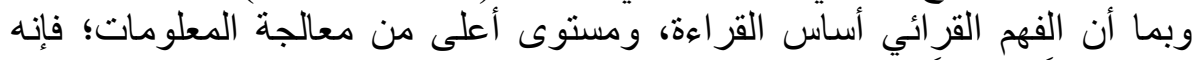

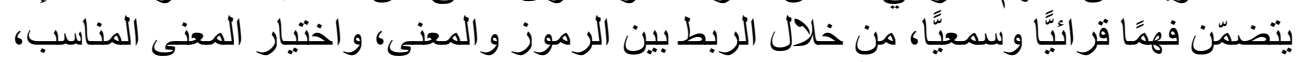

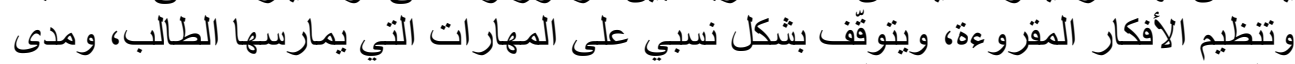

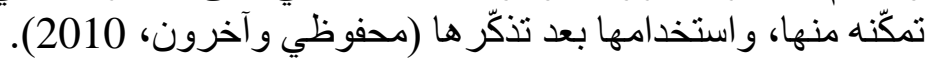

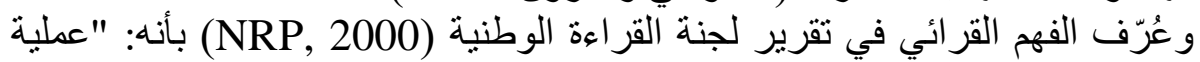

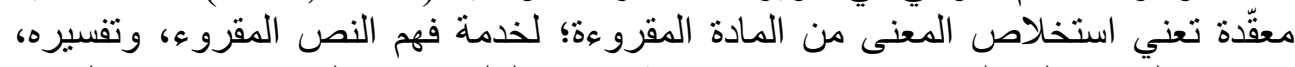

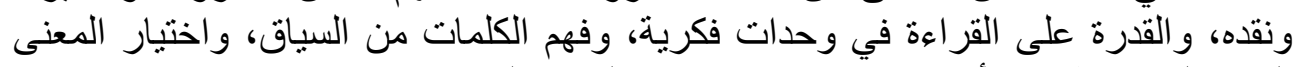

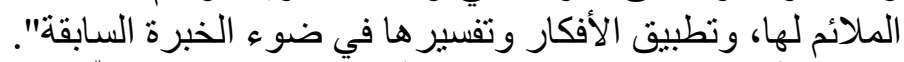

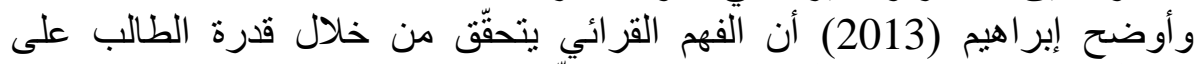

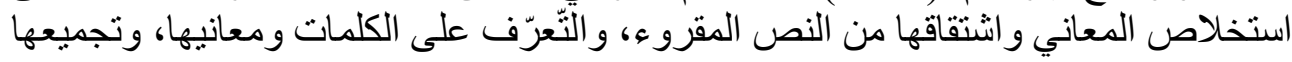

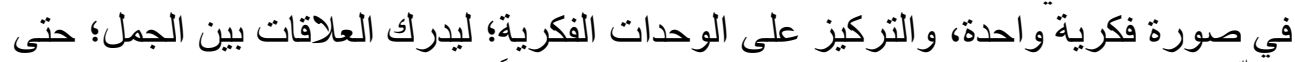

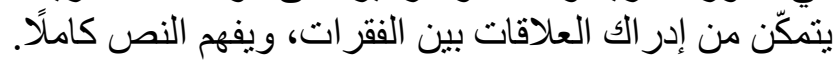
العوامل المؤثرة في الفهم القرائي

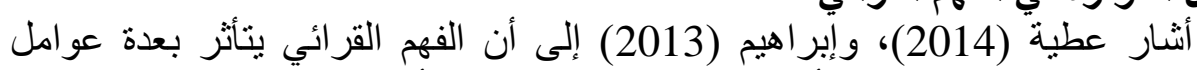

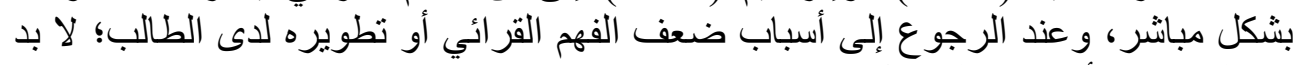
من النظر إلى أحد هذه العو امل، وهي: الرى العباب: 
1- النص المقروء: يشير هذا العامل إلى سلاسة التراكيب اللغوية والنحوية، وسهولة

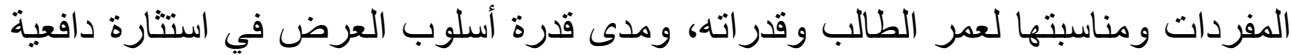
الطالب و انجذابه له.

2- الطالب القارئ: ويعني قدرة الطالب على ربط النص بله بخلفيته الثقافية و المعرفية، وتمكّنه

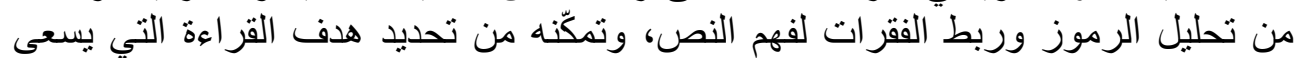

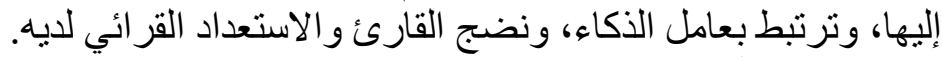

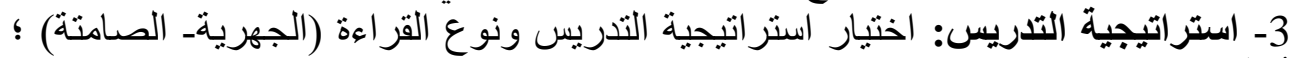

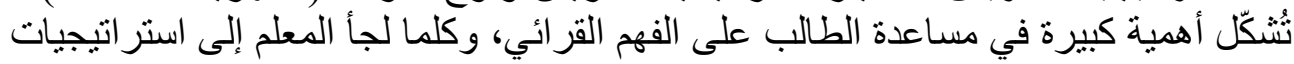
مختلفة؛ سهل على طُلابه الفهم.

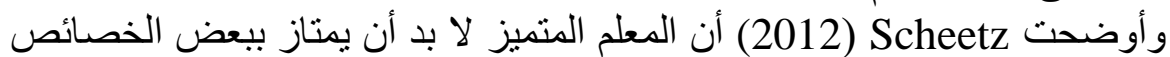

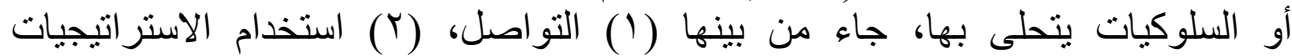

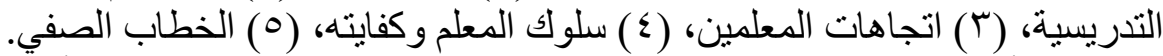

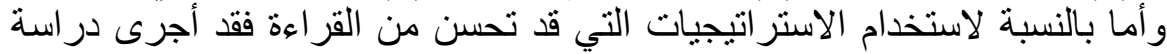
(2006) Easterbrooks and Stephenson

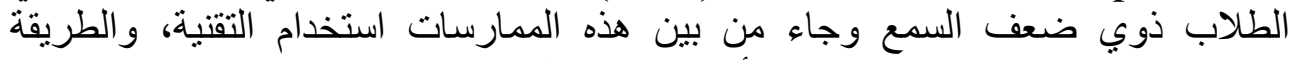

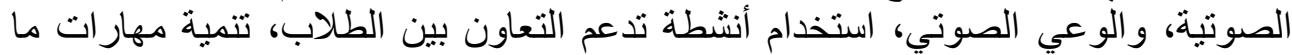
ور اء المعرفة كأنشطة تطبق قبل القر اعة أو أو بعدها.

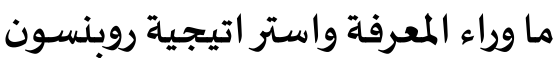

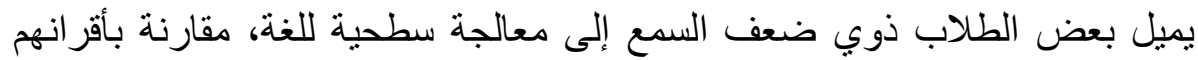

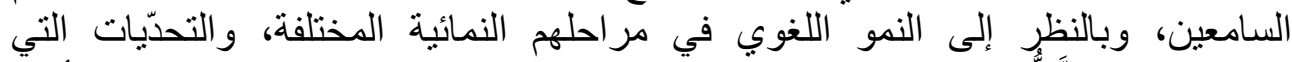

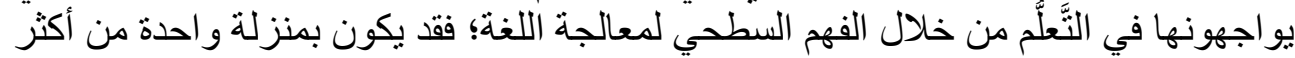

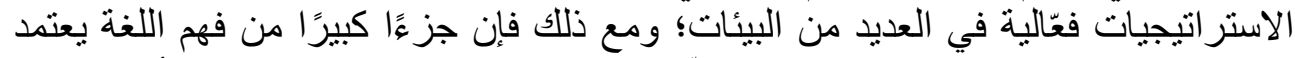

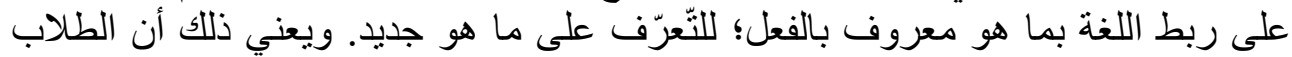

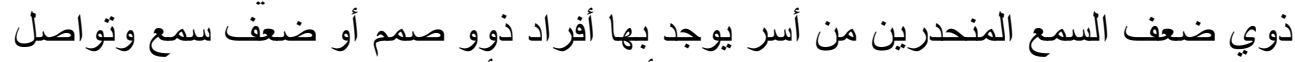

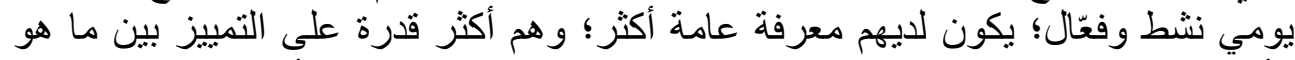

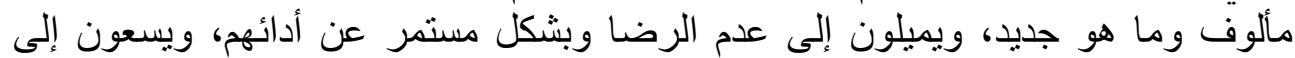

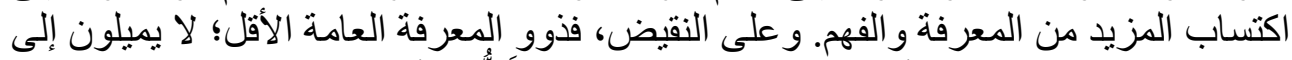

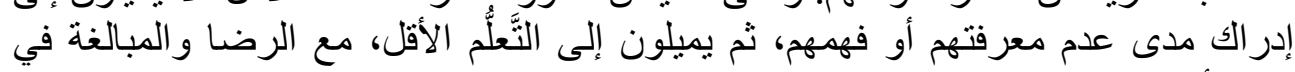
تقدير أدائهم (Marschark \& Hauser, 2008). و وعدما يريد الطالب أن يصل إلى مستوى من الفهم، فعليه أن يعرف وسيلة وسبيلًا

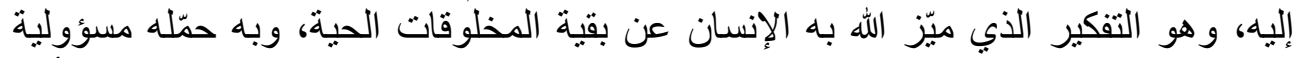
صنع الحياة وقيادتها، بصفته كنز الطاقات والثروة الثيّن التي تزداد بكثرة العطاء، ويعدّ أحد 


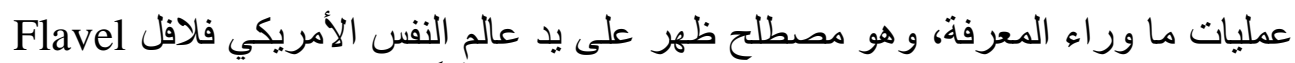

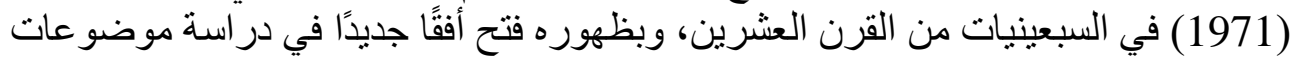

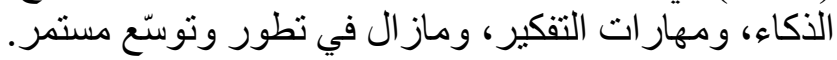

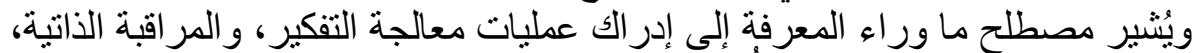

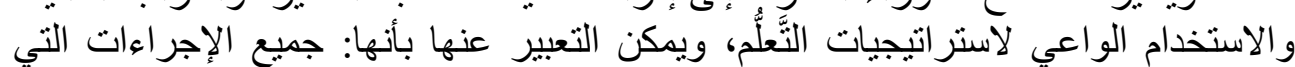

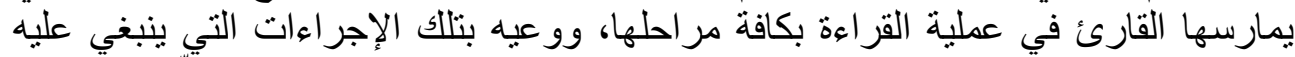

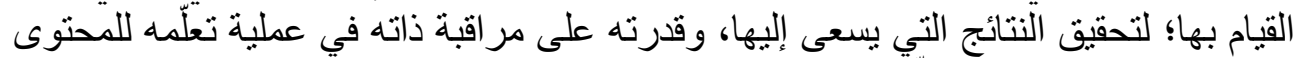

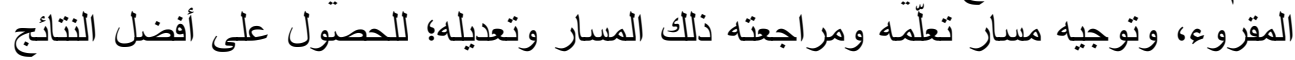

(عطية، 2014).

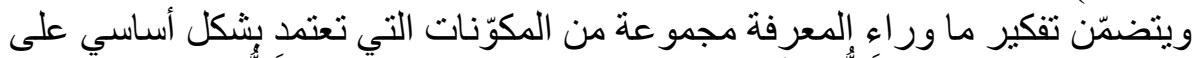

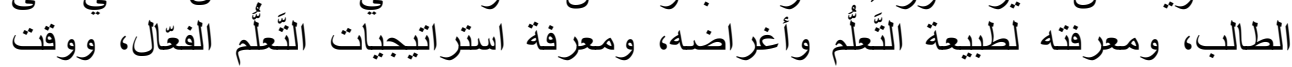

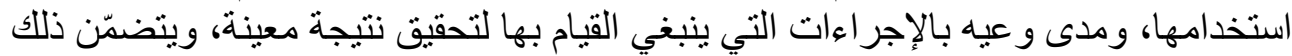

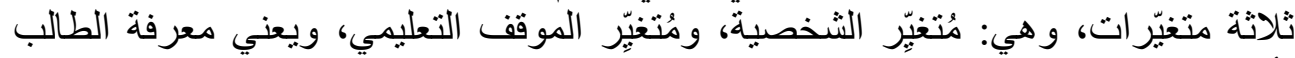

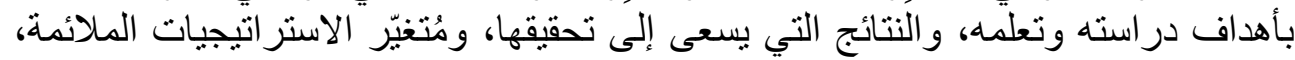

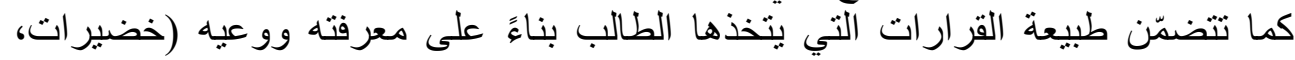

$$
\text { و وعند تطبيق ماور اء المعرفة نجد أربعة مظاهر أساسية هي: }
$$

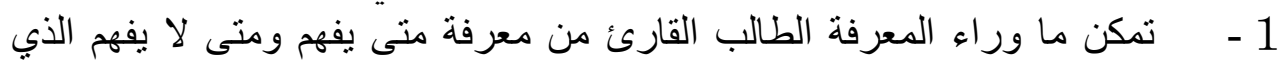

2 - - تمكن الطالب القارئ من تحديد الأشياء التي فهمها و الأشياء التي لم يفهمها.

3 - 3

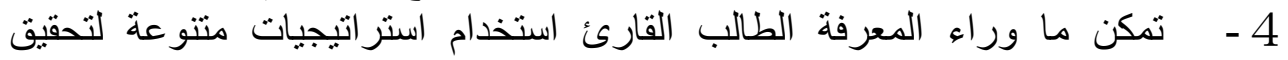
المعلومات التي يحتاج إليها. أسس اختيار استراتيجيات ما وراء التئاء المعرفة البهات

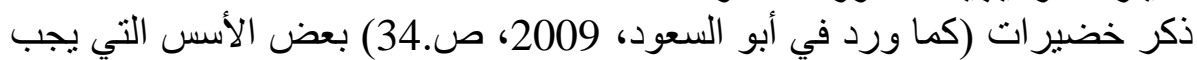
مر اعاتها عند تطبيق هذه الاستر اتيجيات، وأهير أهمها:

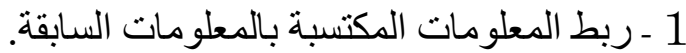

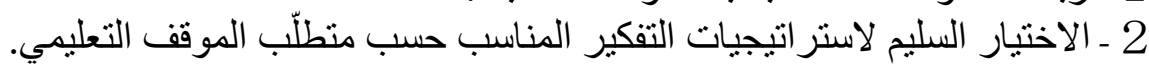

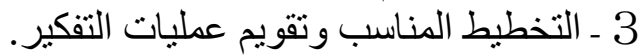

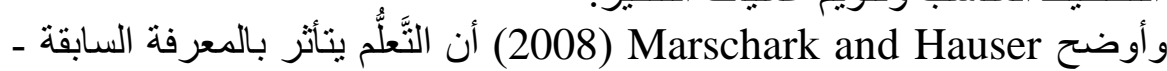

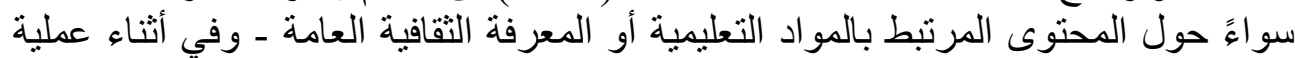
القراعة تساعد المعرفة السابقة على تتظيم المعرفة الجديدة، من خلال الارتباطُة العات الدلالية، 
وفي حين الوصول إلى مرحلة لا يتم فيها ربط المعرفة الجديدة بالمعرفة السابقة بشكل

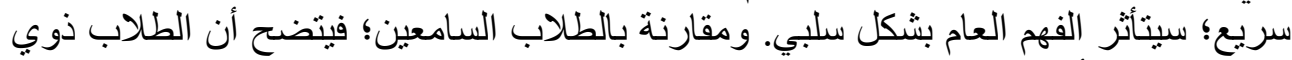

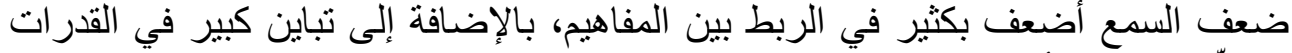

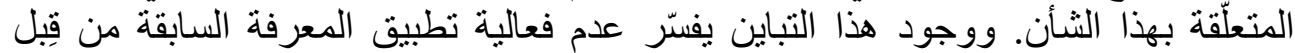
الطلاب ذوي ضعف السمع مقارنة بالطلاب السامعين عبر السياقات الأكاديمية.

(SQ3R) استر اتيجية روبنسون فئسون

تقنية التصفّح - السؤ ال - القراعة ــ الاستذكار ـ المر اجعة (SQ3R) هي أدواة ذهنية

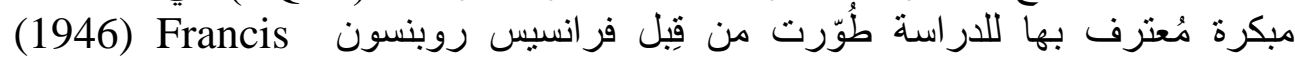
Robinson

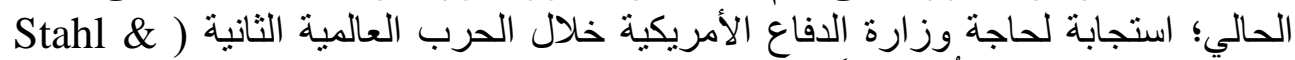

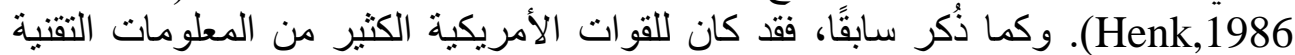

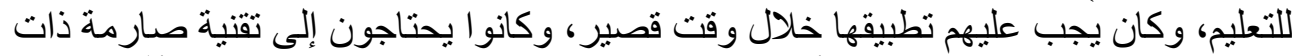

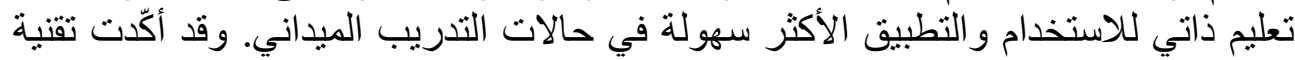

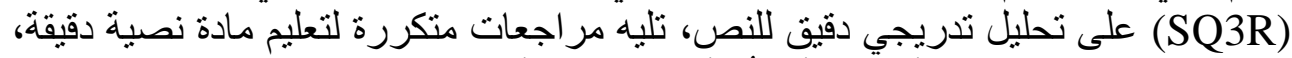

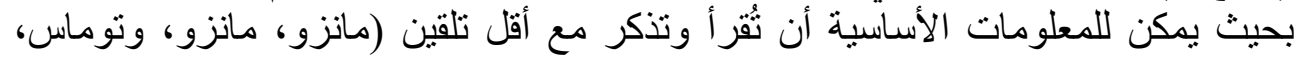
(2008/2004

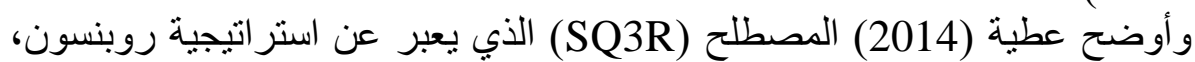

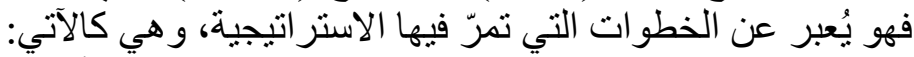

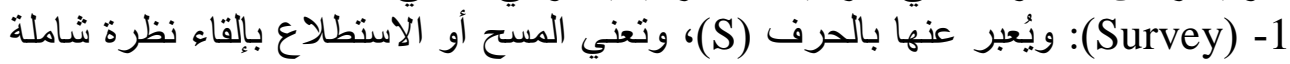

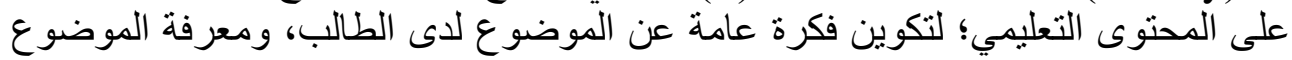
الذي يدور حوله المحتوى التعليمي.

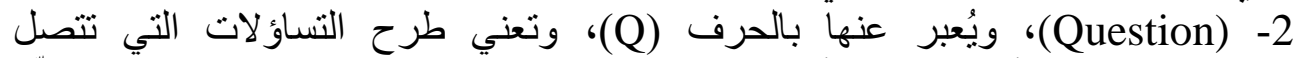

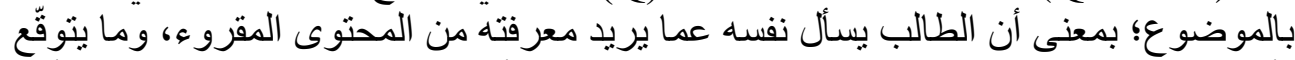

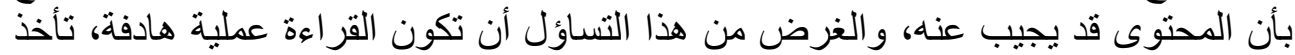

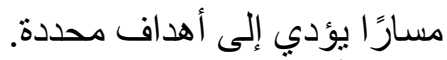
أما بالنسبة للحرف ألماف (R)، الذي يسبقه الرقم (3)، فهو أن الحرف مكرر ثلاث مرات

في ثلاث كلمات مختلفة كالآتي:

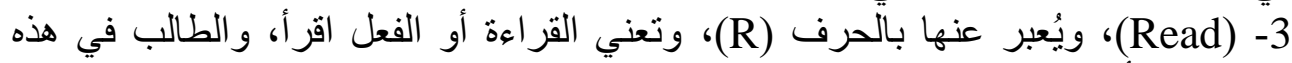

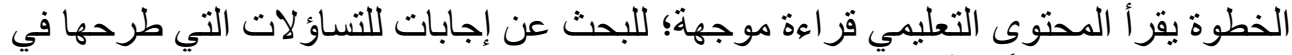

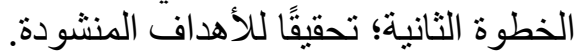

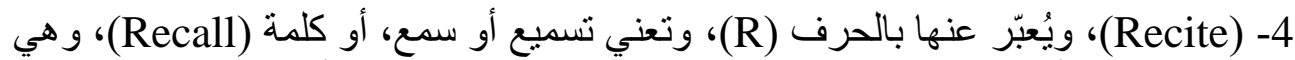
بمعنى استرجع أو استذكر، ويجيب الطالب في هذه الخطوة عن أنس الأسئلة التي طرحها في 


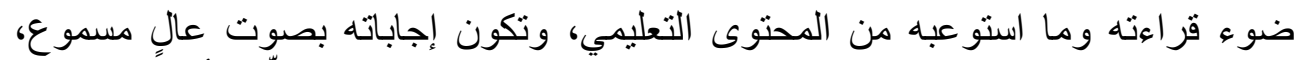

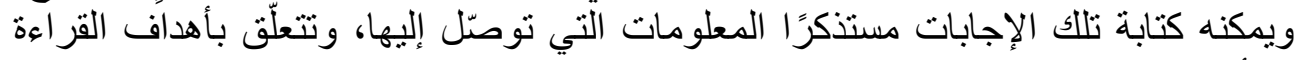
والأسئلة التي طئه طرحها.

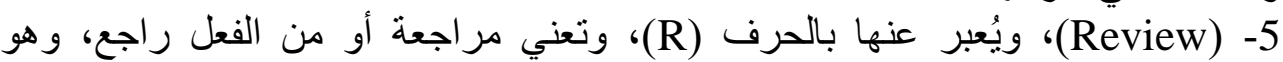

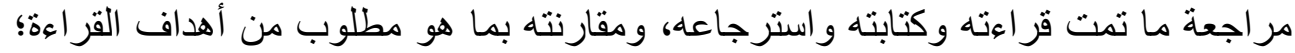

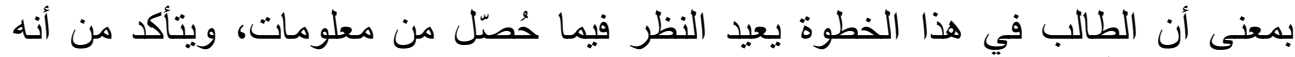

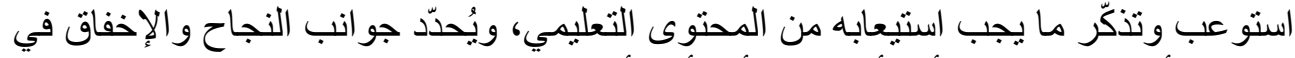

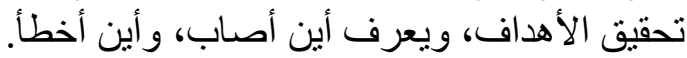
مميزات استر اتيجية روبنسون (SQ3R)

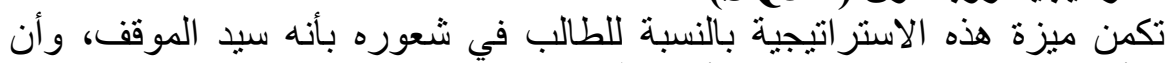

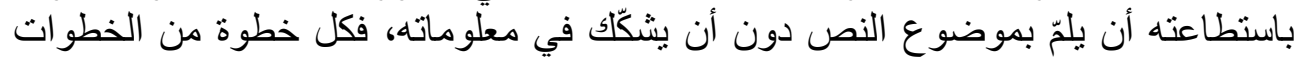

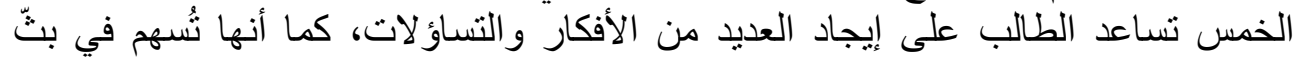

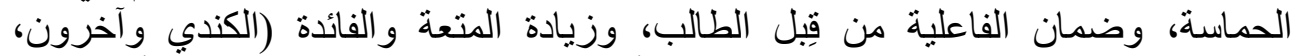

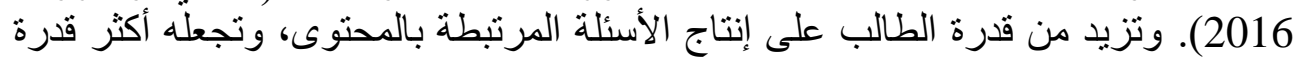

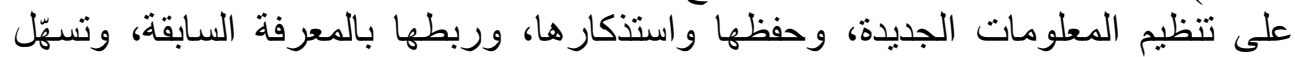

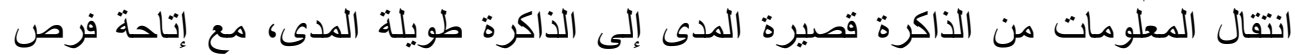

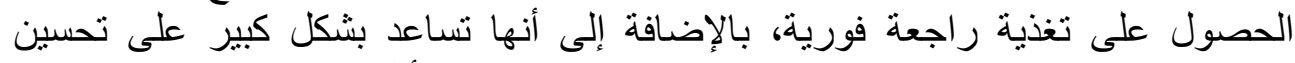

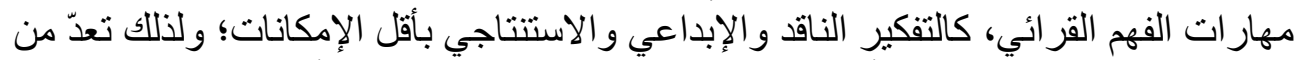

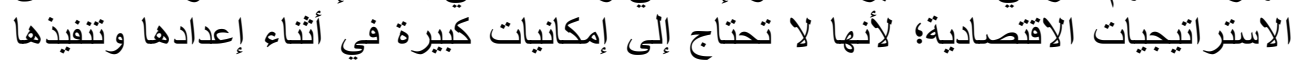

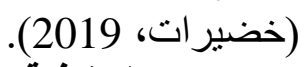

الإجراعات التنفيذية لاستر اتيجية روبنسون (SQ3R)

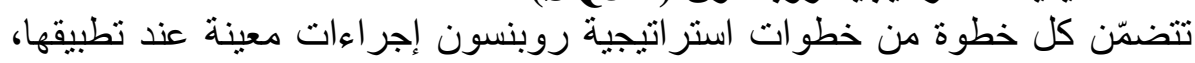

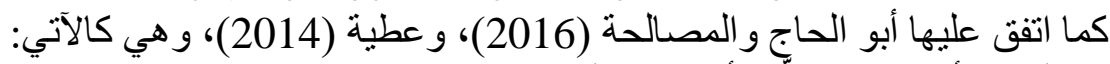

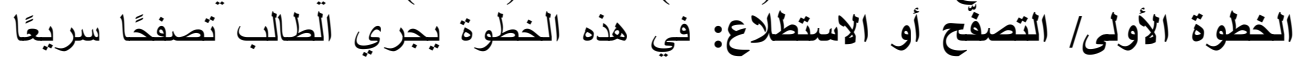

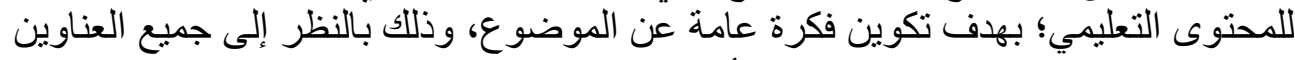

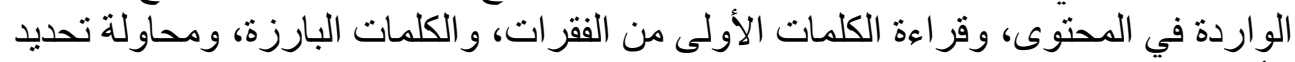

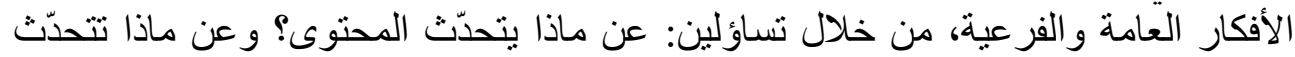
الفقر ات؟

وفي حال كان المحتوى يحتوي على رسوم بيانية أو نوضيحية أو جداول؛ فينبغي على المعلم أن يلفت انتباه الطالب إليها. 


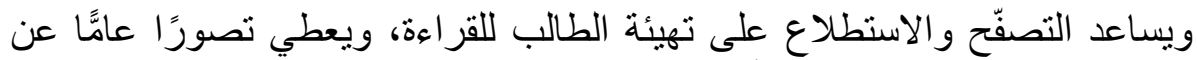

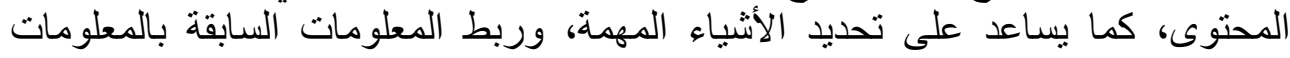

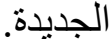

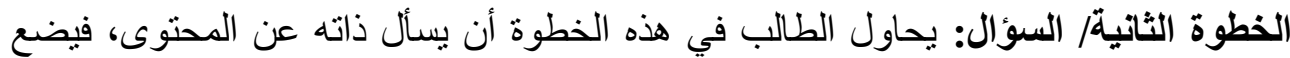

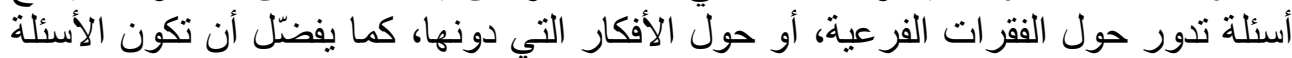

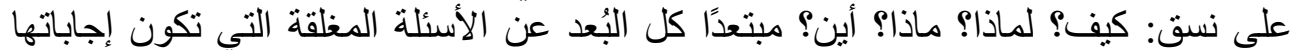

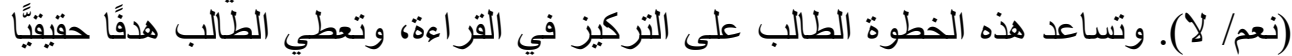

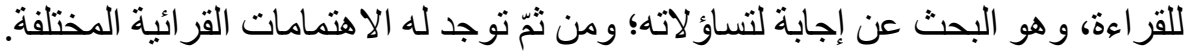

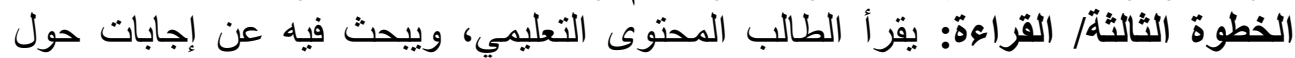

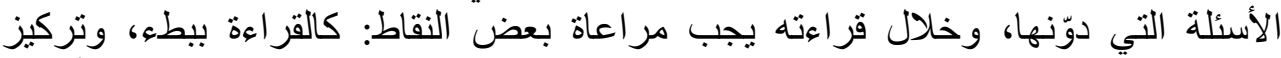

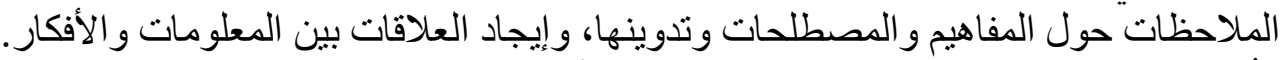

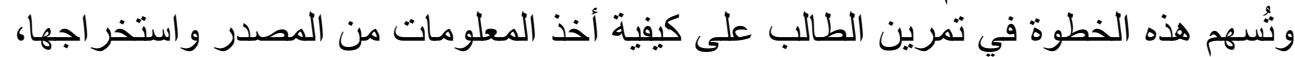

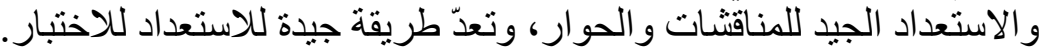

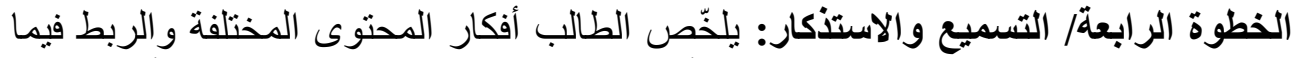

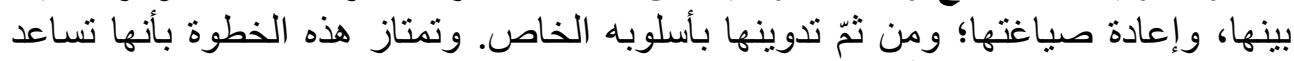

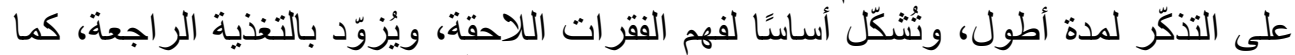

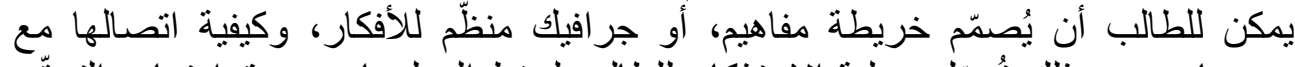

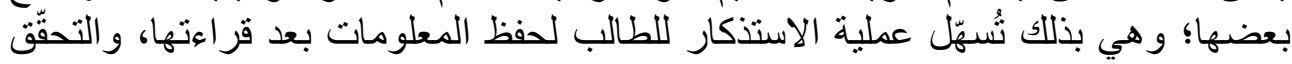

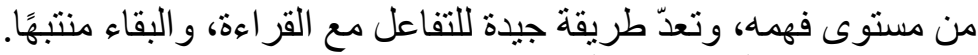

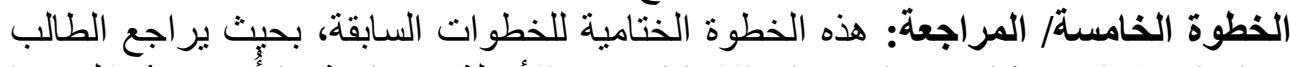

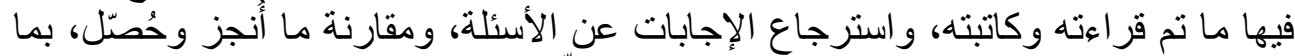

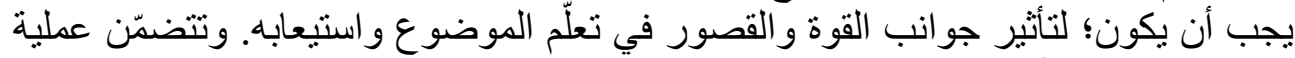

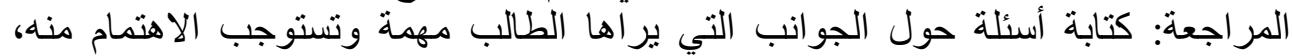

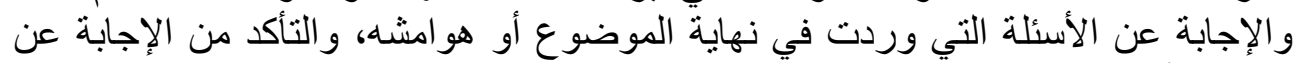

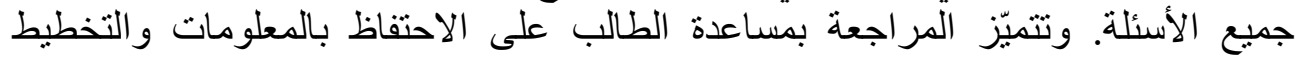

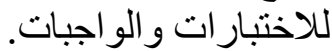
الار اسات السابقة

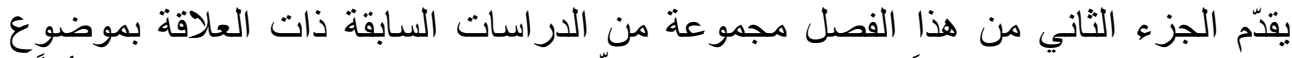

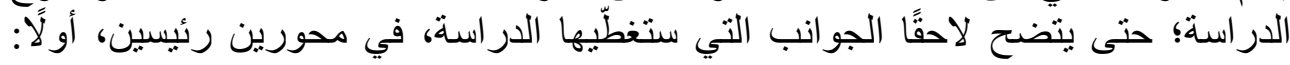

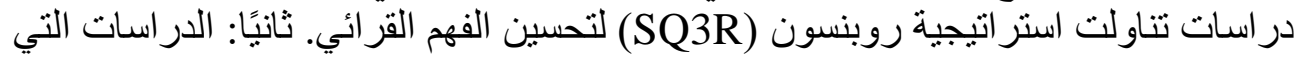

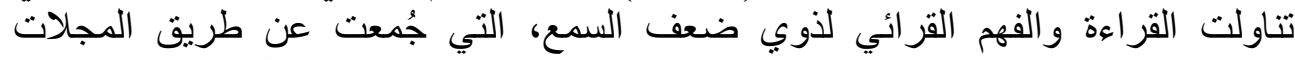

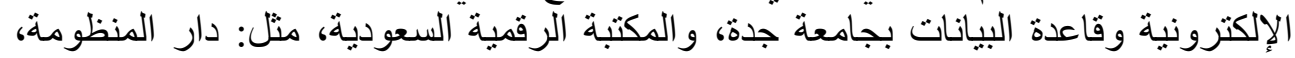


و آسك زاد، والمنهل، و أبيسكو وغير ها، وتُعرض فيها الدر اسات بناءً على طريقة تطبيقها، ويكون ترتيبها من الأحدث إلى والي الأقدم، كالآتئي 1- دراسات تناولت استر اتيجية روينسون (SQ3R) لتحسين الأنئ الفهم القرائي

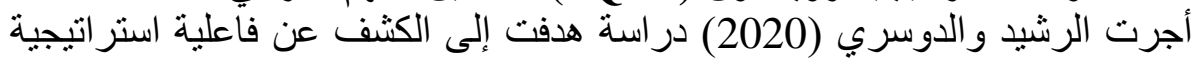

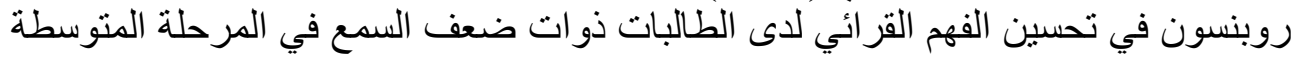

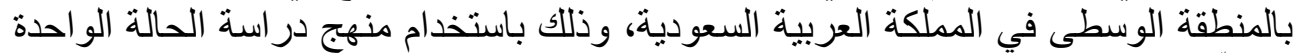

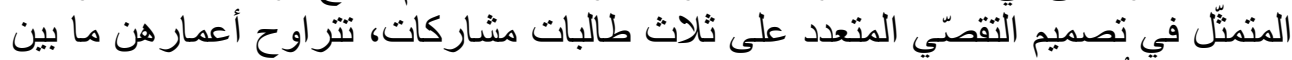

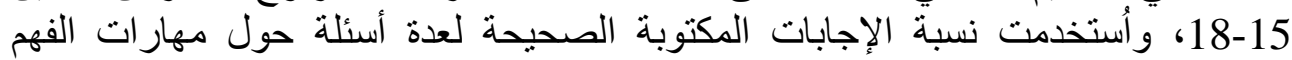

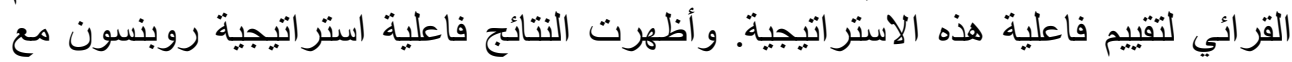

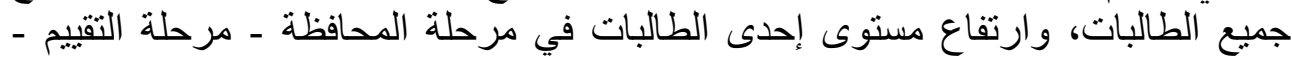

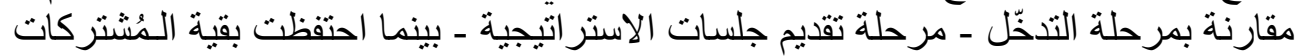
في المستوى نفسه الذي توصّلن إلبه في مرحلة التدخّل.

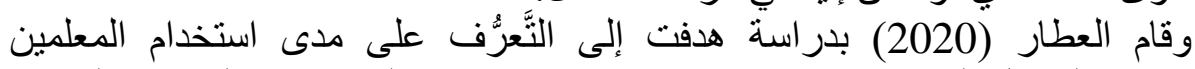

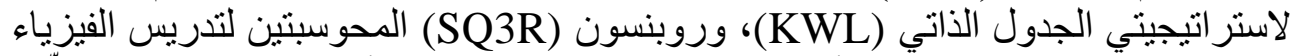

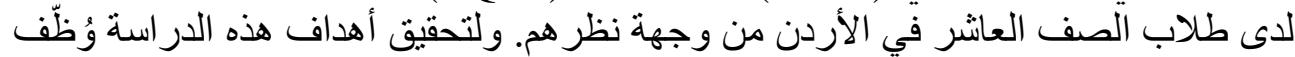

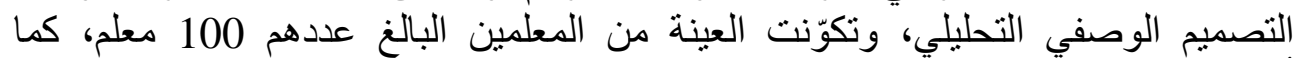

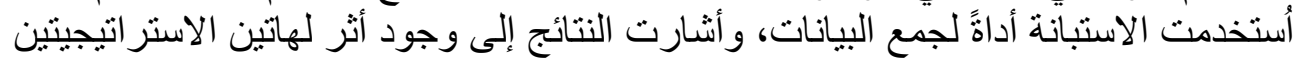

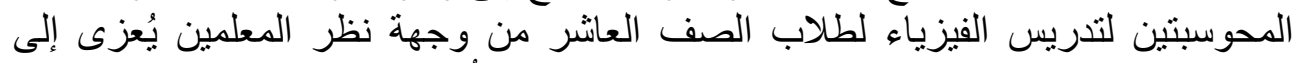

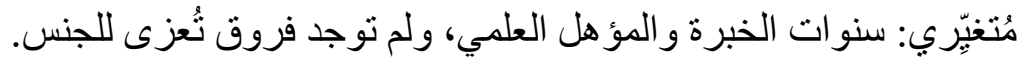

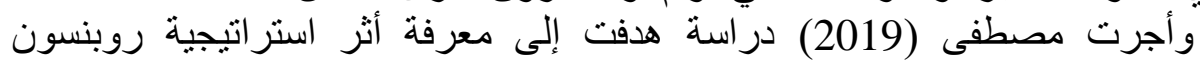
(SQ3R)

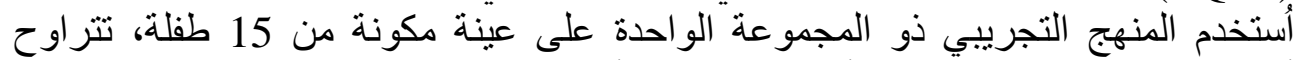

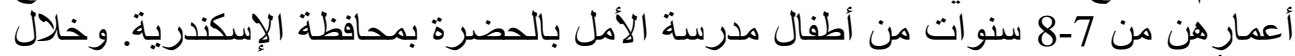

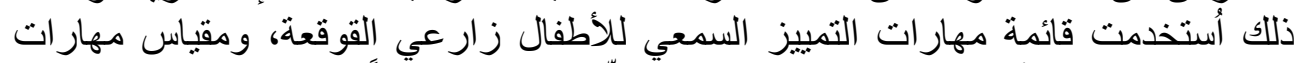

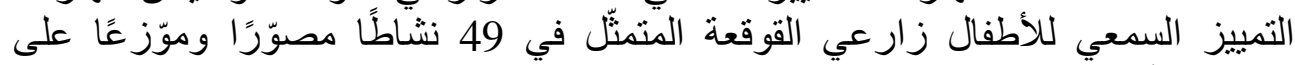

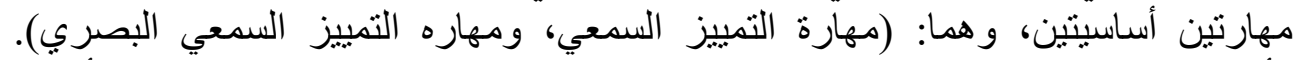

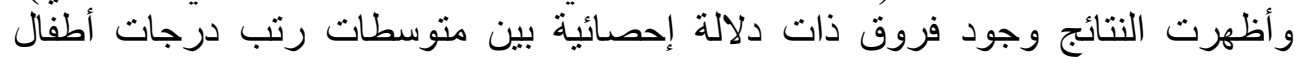

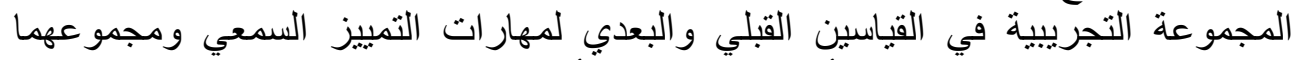
الكلي؛ لصالح القياس البعدي. وأوصت الدئ الدراسة بأهمية تطبيق الاسترات التيجية التئية على مهارات

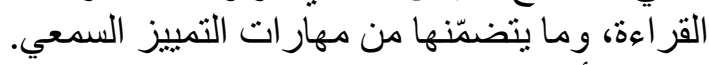
وأجرى المعلوي (2019) در استة هدفت إلّى التَّرُّف على التى فاعلية استخدام استر اتيجية روبنسون (SQ3R) في تدريس العلوم على التحصيل وتنمية عمليات العلم التكاملية لدى التى 
طلاب المرحلة المتوسطة. ولتحقيق ذلك أستخدم المنهج التجريبي القائم على التصميم شبه

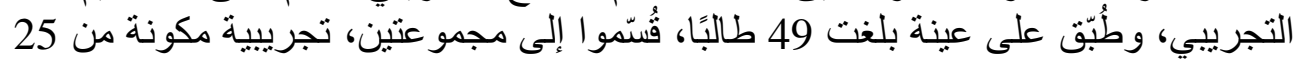

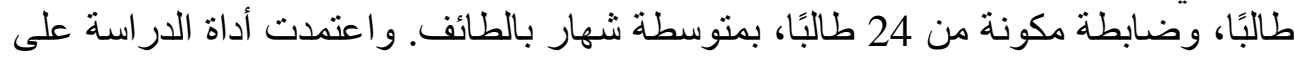

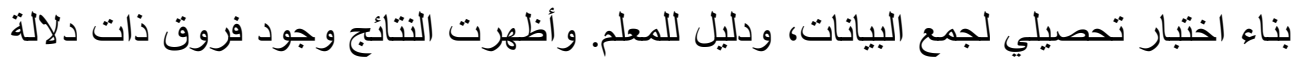

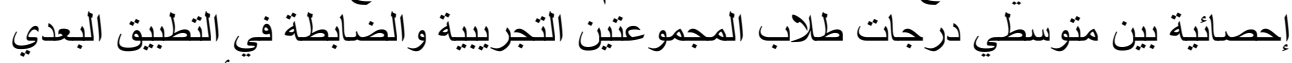

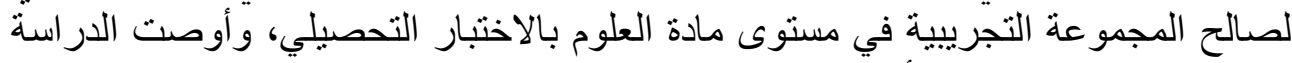

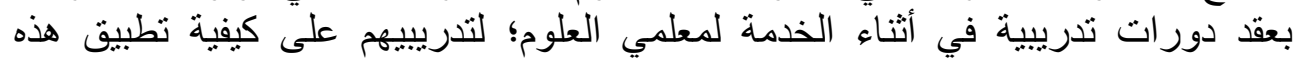

وأجرى (2019) Anjuni and Cahyadi دراسة هدفت إلى معرفة أثر استخدام الاستر اتيجية. استراتيجية روبنسون (SQ3R) في تحسين الفهم القرائي لدى الطلاب. ولتحقيق أهداف هذه الته

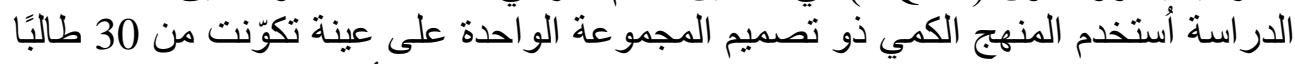

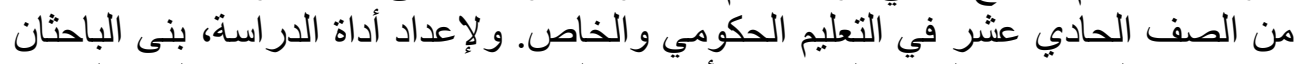

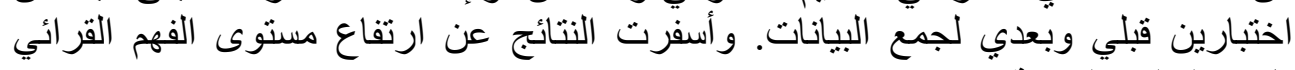
باستخدام استر اتيجية روبنسون (SQ3R).

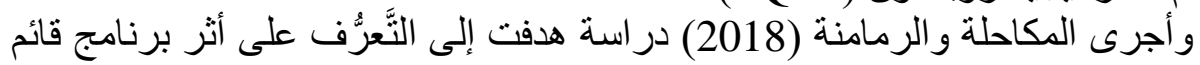

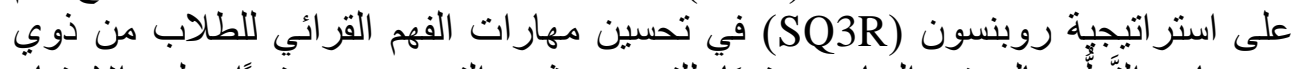

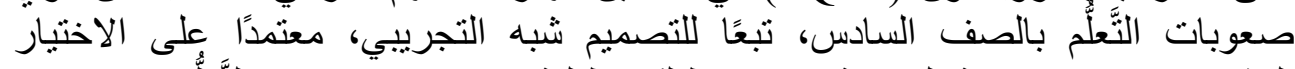

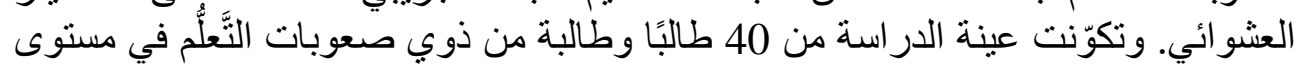

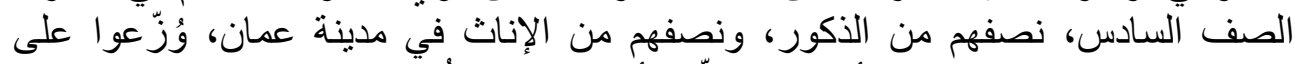

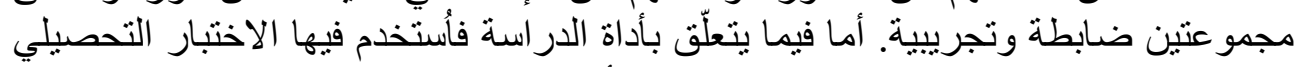

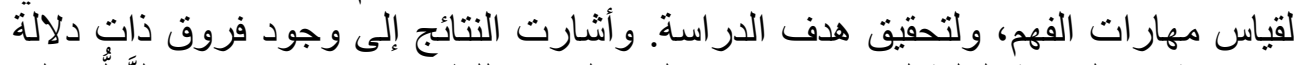

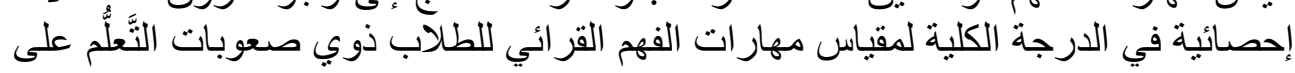

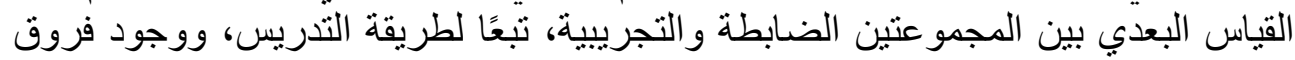

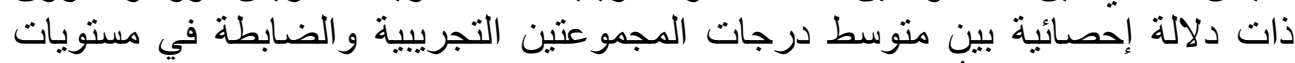

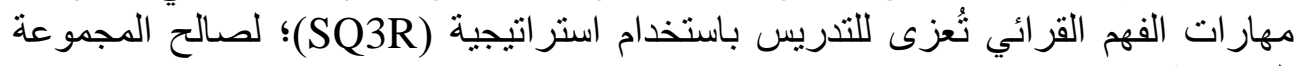
التجريبية.

2- الاراسات التي تناولت القراعة والفهم القرائي لذوي ضعف السمع

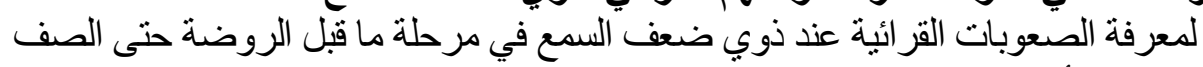

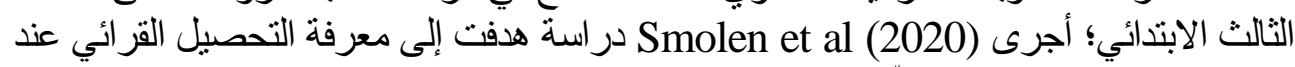

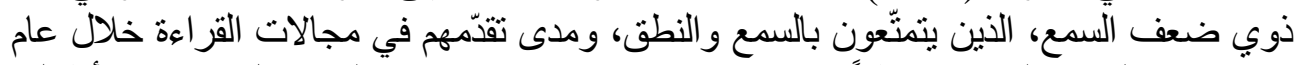

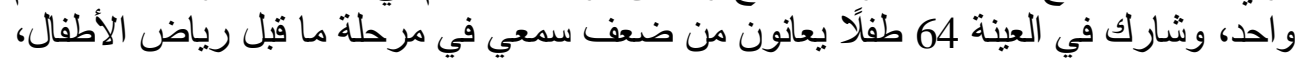

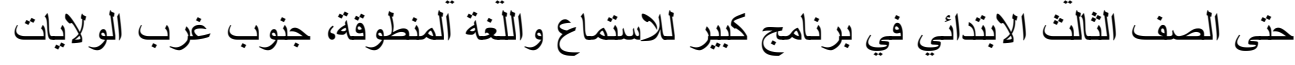




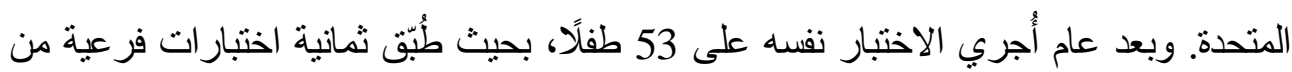

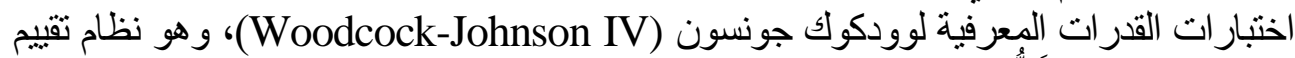

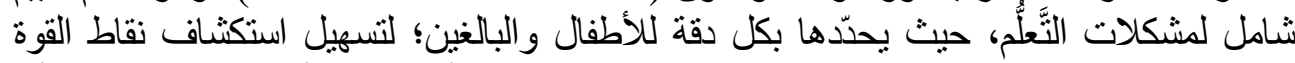

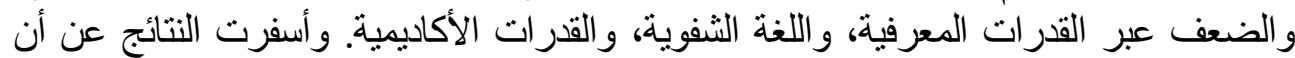

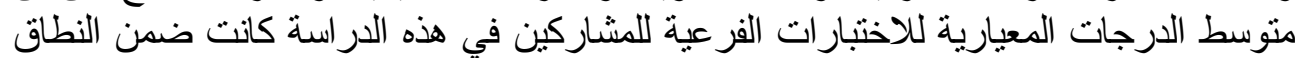

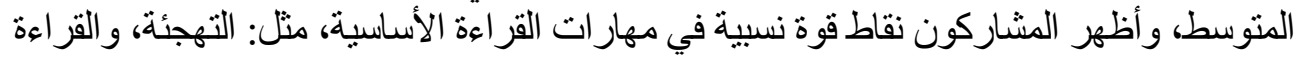

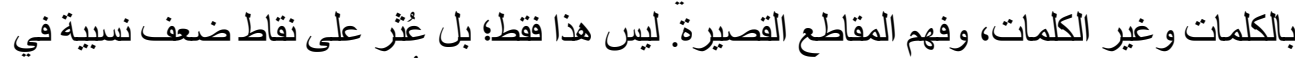

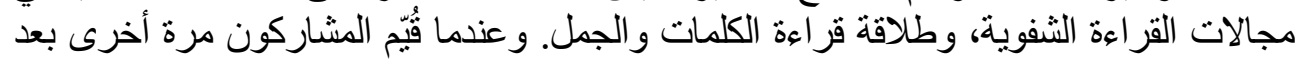

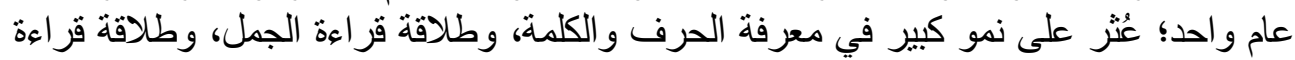

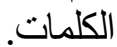

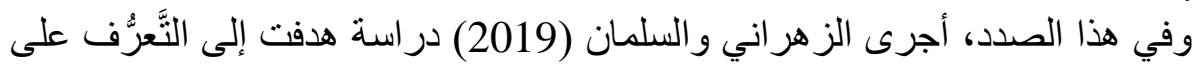

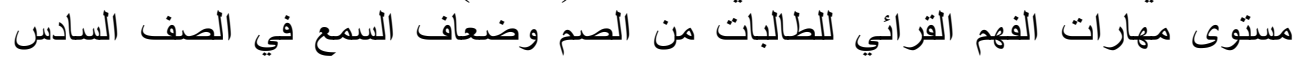

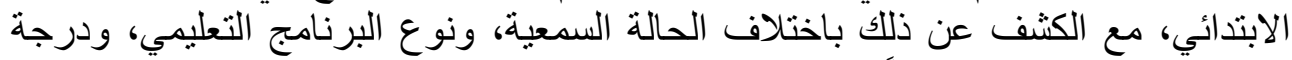

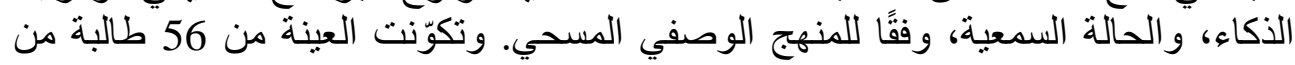

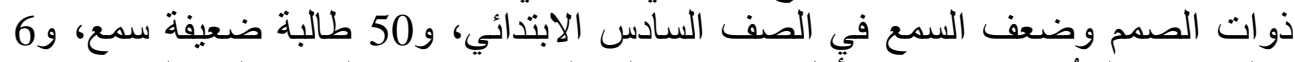

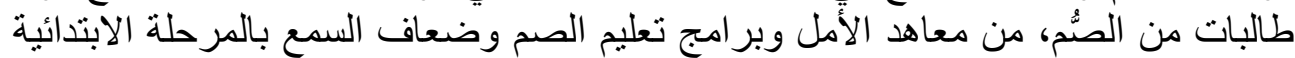

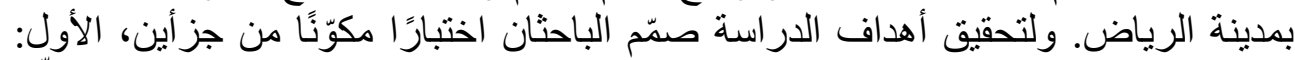

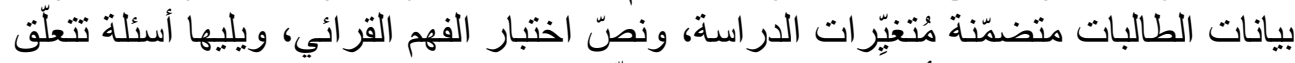

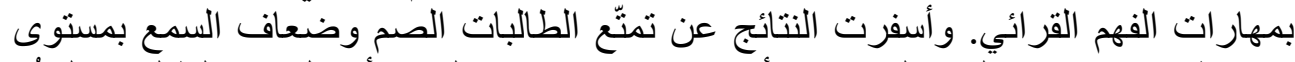

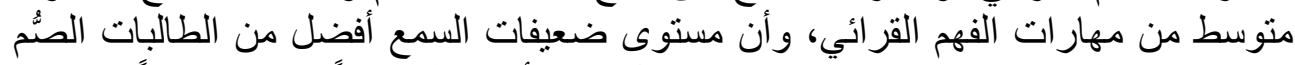

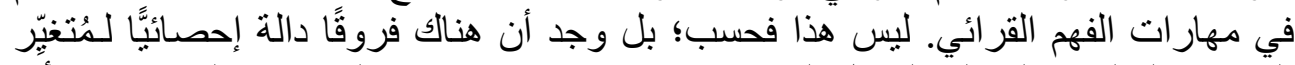

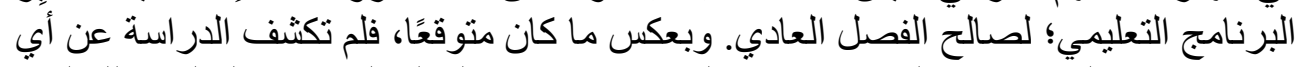

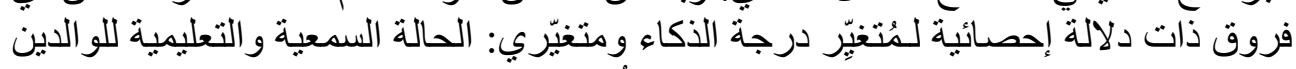

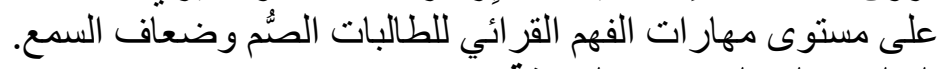

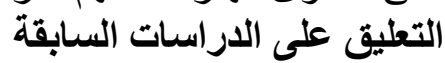
نظرًا لأهمية الفهم القرائي في العملية التعليمية التربوية، وتأثيره المباشر في التحصيل

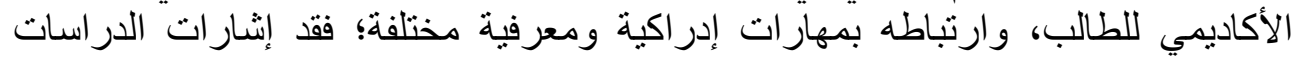

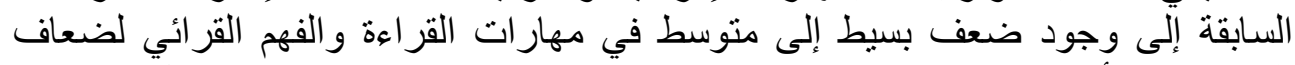

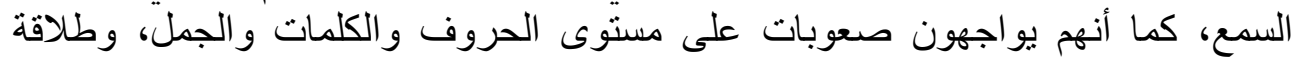

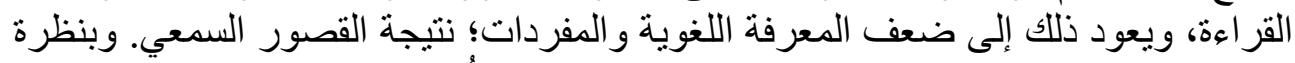

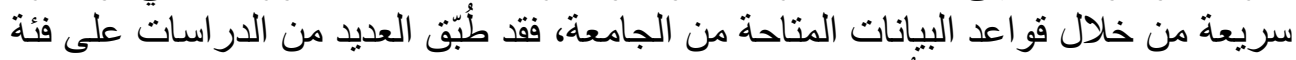

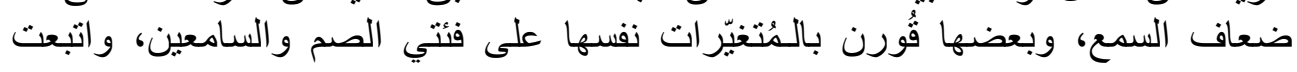


الدراسات عددًا من المناهج كالوصفي المسحي، أو الوصفي التحليلي، من خلال تطبيق

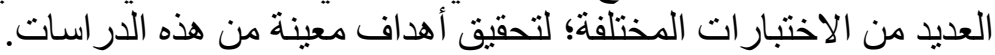

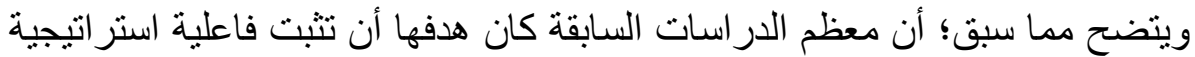
روبنسون في تحسين الفهم القرائي أو الجوانب الأخرى للطابلاب ذوبي الإعاقة أو أو الطبيعيين.

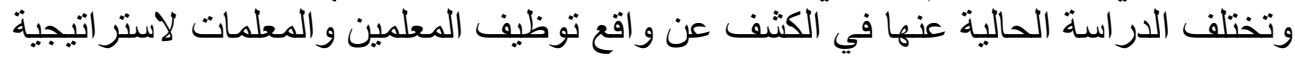

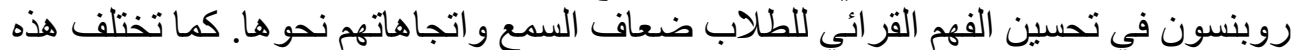

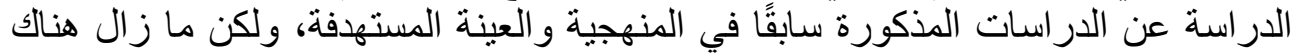

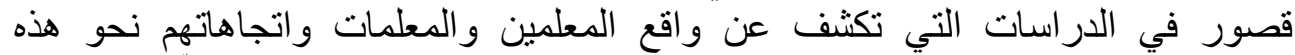

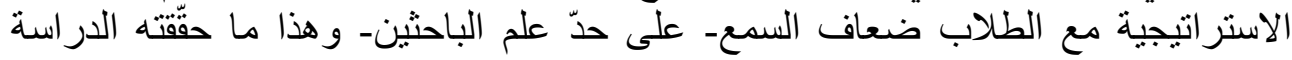
الحالية.

منهجية الاراسة واجراء|تها منهج الاراسة منهة الدراسة

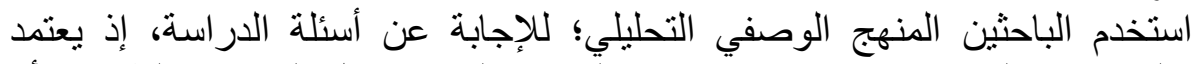

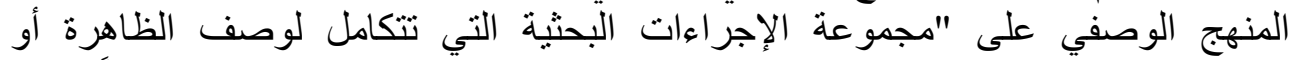

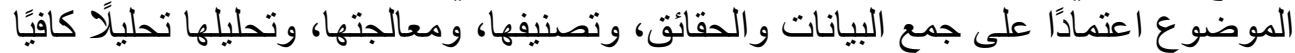

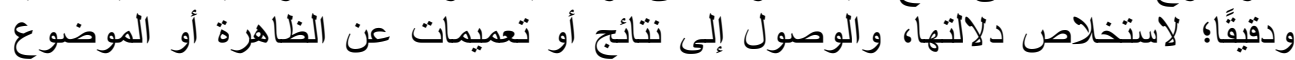

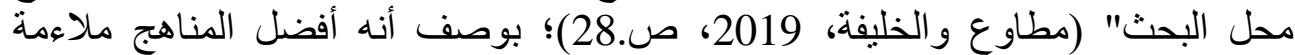

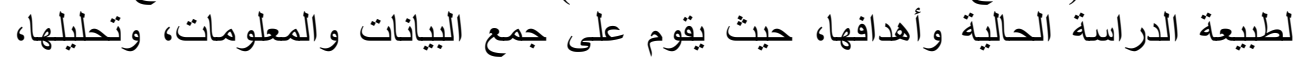

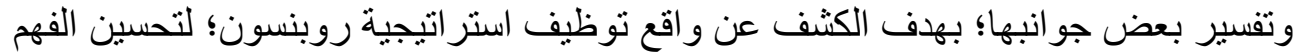

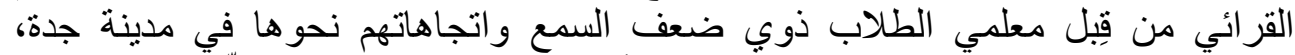

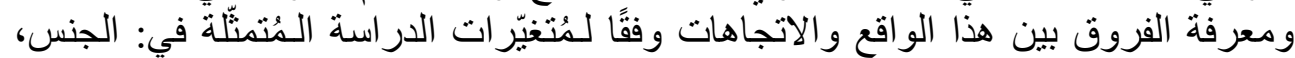

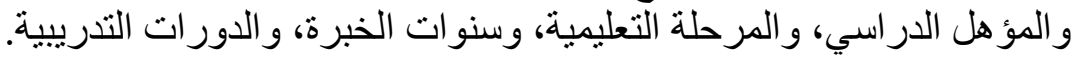
مجتمع الدراسـة ملية

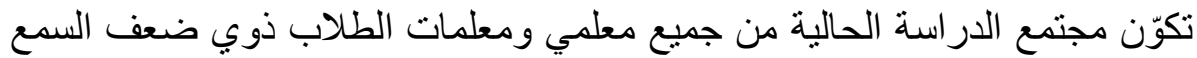

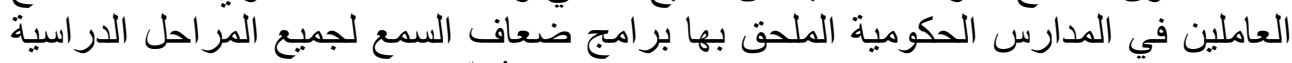

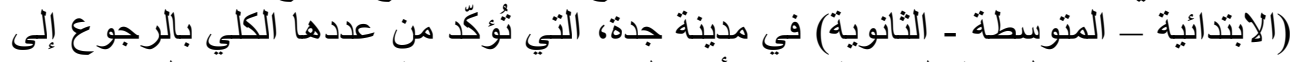

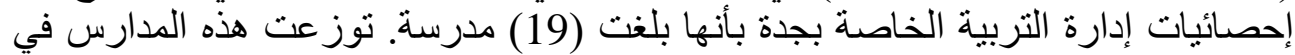

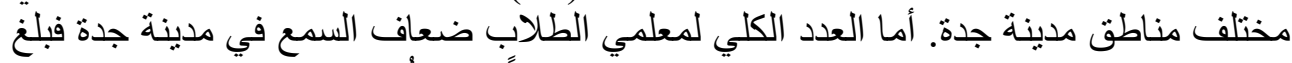

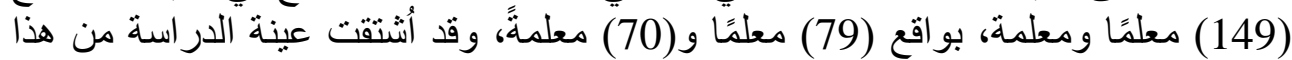

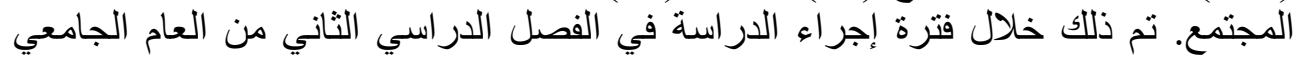


استخدم الباحثين في اختيار العينة الأسلوب العشوائي، وهي مجموعة جزئية منتقاة

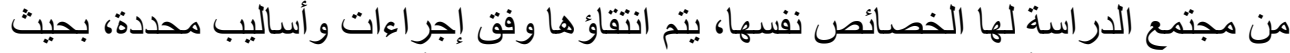

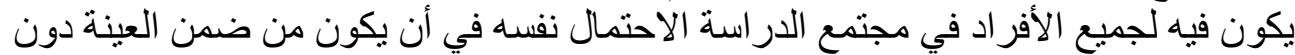

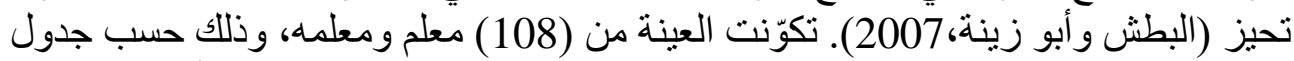

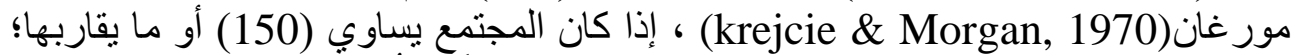

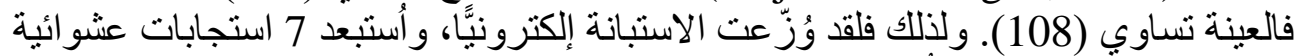

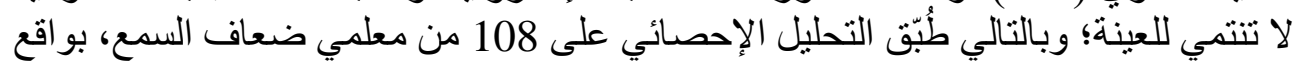

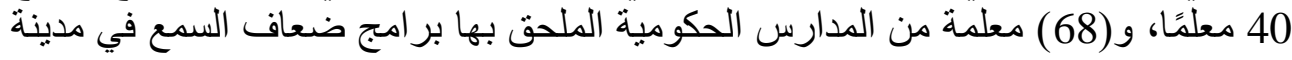

أداة الاراسة

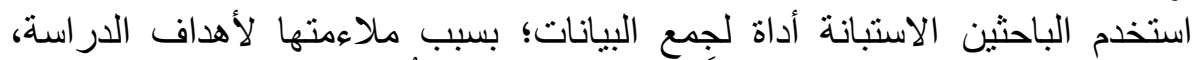

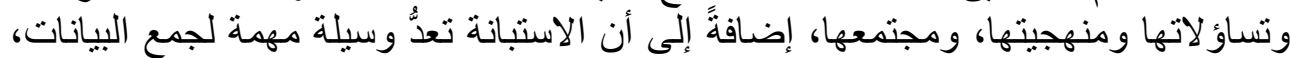

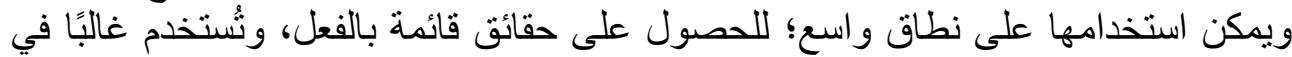

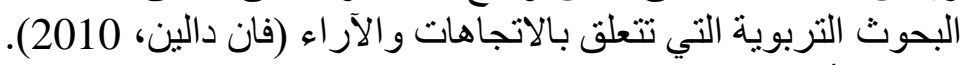

وصف الأداة

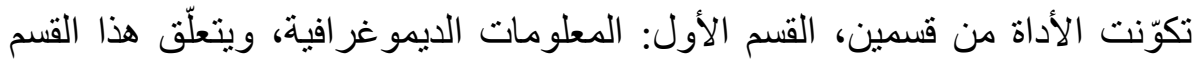

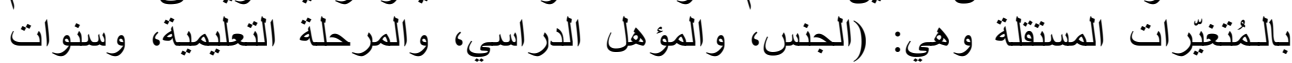

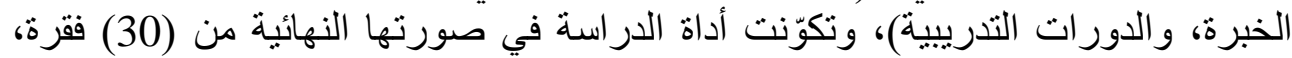

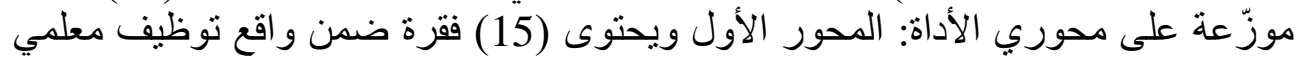

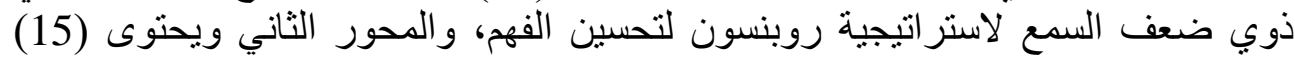

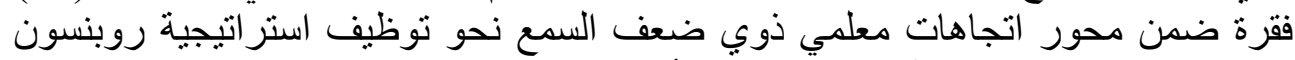

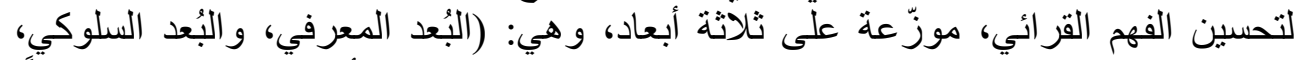

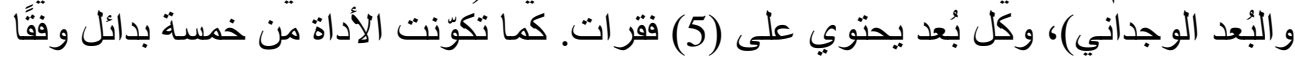

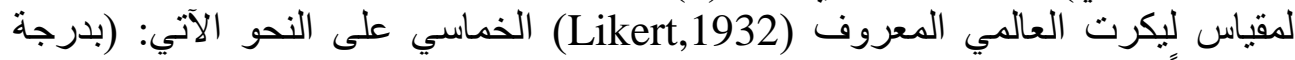
كبيرة جدَّا بدرجة كبيرةت بدرجة العبرة متوسطة، بدرجة ضعيفة، بدرجة معدومة).

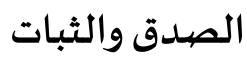
صدق أداة الدراسة والثبات

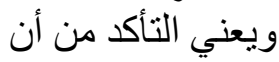

العبارة الموضوعة في المقياس تقيس فعلياً ما وُضعت لقياسه (الظاهر، 1999)،

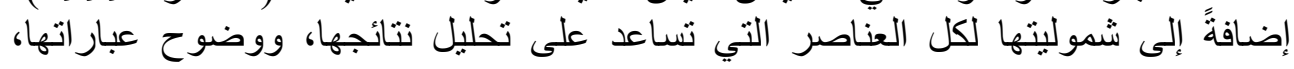


و وارتباطها بكل محور وبُعد من أبعاد أداة الدراسة، بحيث تكون مفهومة لكل من يستخدمها،

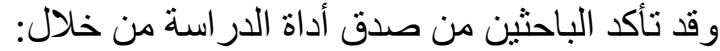

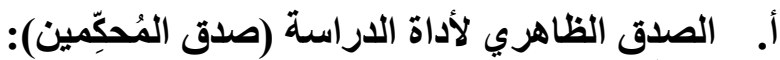

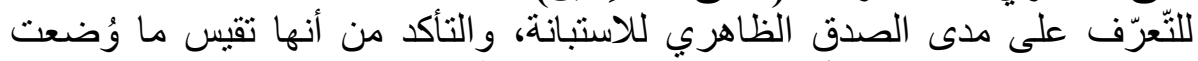

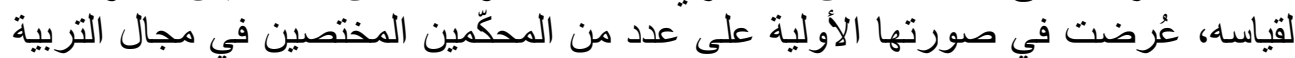

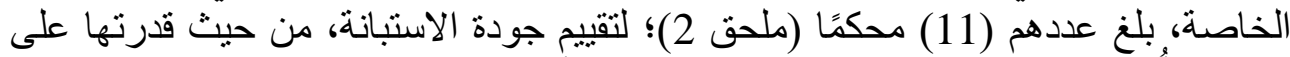

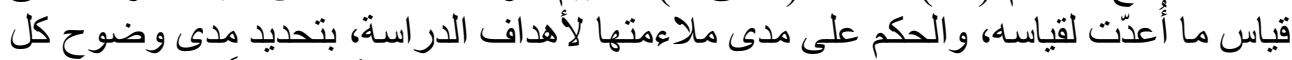

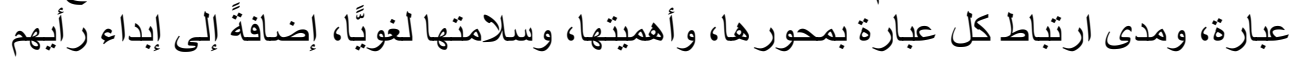

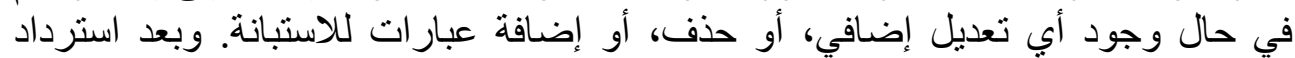

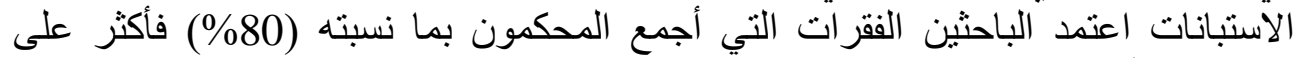

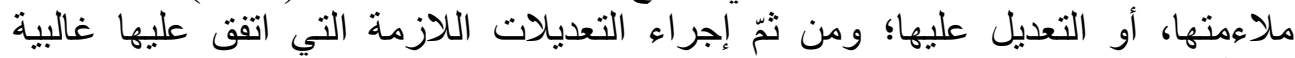

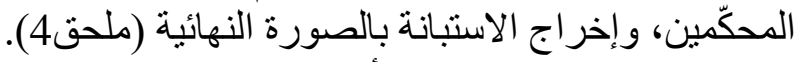
ب. صدق الاتساق الداخلي للأداة

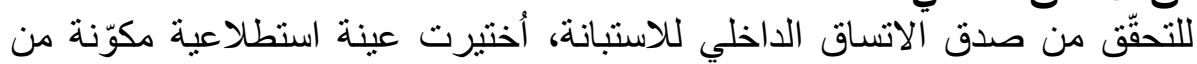

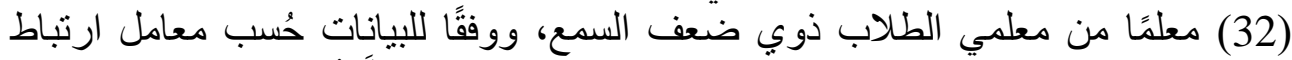

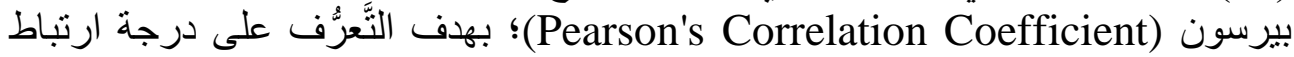

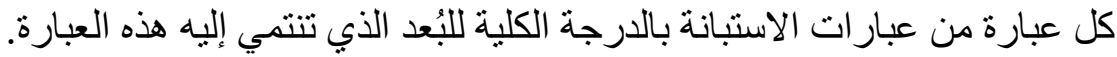

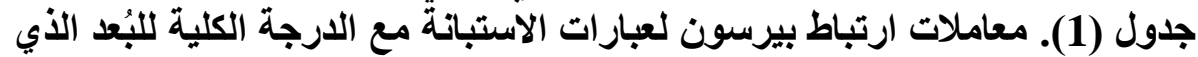

تنتمي إليه.

(واقع توظيف استراتيجية روبنسون لتحسين الفهم القرائي من قِبل معلمي ذوي ضعف السمع و اتجاهاتهم نحوها في مدينة جدة)

\begin{tabular}{|c|c|c|c|c|c|}
\hline بالارتباط & العبارة & الارتباط & العبارة & 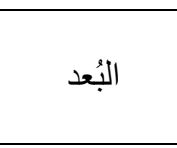 & 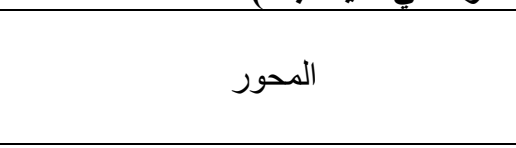 \\
\hline$* * 0.558$ & 4 & $* * 0.665$ & 1 & \multirow{3}{*}{ البُعد الأول: } & \\
\hline$* * 0.768$ & 5 & $* * 0.687$ & 2 & & \\
\hline- & - & $* * 0.728$ & 3 & & \\
\hline$* * 0.518$ & 4 & $* * 0.498$ & 1 & \multirow{3}{*}{ البُعد الثاني: } & اتجاهات المعلمين/المعلمات نحو توظيف \\
\hline$* * 0.562$ & 5 & $* * 0.872$ & 2 & & استراتيجية روبنسون لتحسين الفهم \\
\hline - & - & $* * 0.768$ & 3 & & القر ائي للطلاب ذوي ضعف السمع \\
\hline$* * 0.605$ & 4 & $* * 0.567$ & 1 & \multirow{3}{*}{ البُعد الثالث: } & \\
\hline$* * 0.630$ & 5 & $* * 0.801$ & 2 & & \\
\hline- & - & $* * 0.605$ & 3 & & \\
\hline$* * 0.7329$ & 9 & $* * 0.641$ & 1 & \multicolumn{2}{|c|}{ و اقع توظيف استر اتيجية روبنسون لتحسين الفهم القرائي } \\
\hline
\end{tabular}


(واقع توظيف استراتيجية روينسون لتحسين الفهم القرائي من قِبل معلمي ذوي ضعف السمع واتجاهاتهم

\begin{tabular}{|c|c|c|c|c|c|}
\hline الارتباط & العبارة & 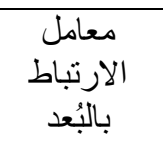 & العبارة & البُعد البُ & المحور \\
\hline$* * 0.875$ & 10 & $* * 0.852$ & 2 & & للطلاب ذوي ضعف السمع \\
\hline$* * 0.719$ & 11 & $* * 0.2202$ & 3 & & \\
\hline$* * 0.608$ & 12 & $* * 0.638$ & 4 & & \\
\hline$* * 0.802$ & 13 & $* * 0.750$ & 5 & & \\
\hline$* * 0.534$ & 14 & $* * 0.719$ & 6 & & \\
\hline$* * 0.541$ & 15 & $* * 0.632$ & 7 & & \\
\hline - & - & $* * 0.486$ & 8 & & \\
\hline
\end{tabular}

* دال عند مستوى الدلالة (0.01) فأقل.

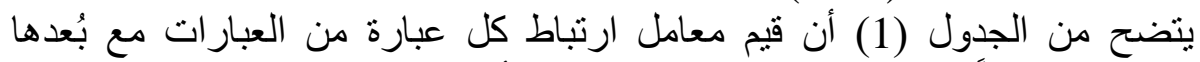

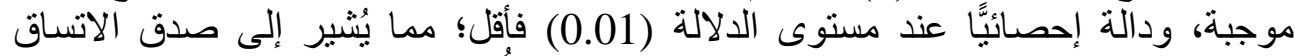

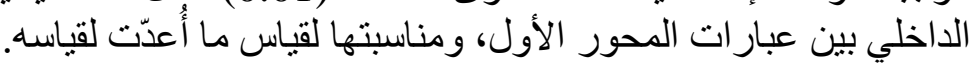

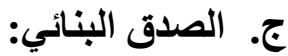

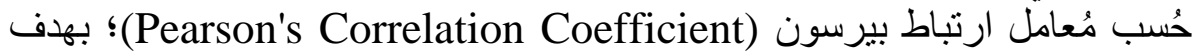
التَّرُّف على درجة ارتباط كل بُعد من أبعاد الاستبانة بالدرجة الكلية للاستبانة، وكانت

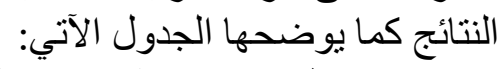

جدول (2). معاملات ارتباط بيرسون لمجالات الاستبانة مع الارجة الكلية.

\begin{tabular}{|c|c|}
\hline معامل الارتباط بالدرجة الكلية & البُعد \\
\hline $.738 * *$ & البُعد الأول: المعرفي \\
\hline $.788 * *$ & البُعد الثاني: السلوكي \\
\hline $.896 * *$ & البُعد الثالث: الوجداني \\
\hline $.866 * *$ & 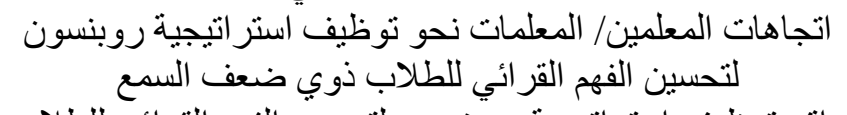 \\
\hline $.856 * *$ & فهم القر ائي للطال \\
\hline
\end{tabular}

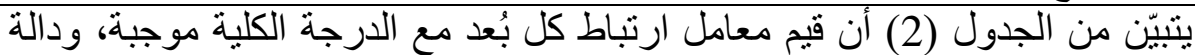

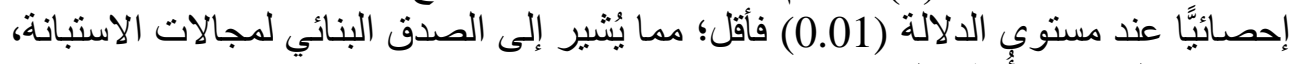
ومناسبتها لقياس ما أُعدّت لقياسـ. 
ثبات أداة الاراسة

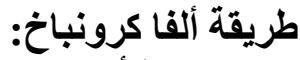
تم التأكد من ثبات أداة الدراسة من خلاخل استخدام معامل الثبات ألفا كرونباخ (معادلة

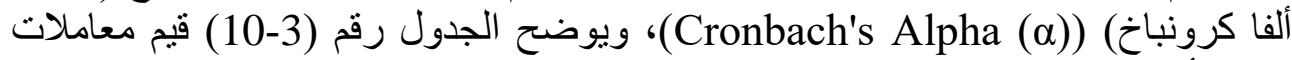
الثبات ألفا كرونباخ لكل محور من محاور الاستبانة. جدول (3). معامل ألفا كرونباخ لقياس ثبات أداة الدراسة.

\begin{tabular}{|c|c|c|}
\hline ثبات المحور & عدد العبارات & البُعد \\
\hline 0.897 & 5 & البُعد الأول: المعرفي \\
\hline 0.809 & 5 & البُعد الثاني: السلوكي \\
\hline 0.848 & 5 & البُعد الثالث: الوجداني \\
\hline
\end{tabular}

0.825 اتجاهات المعلمين/المعلمات نحو توظيف استراتيجية روبنسون التئي

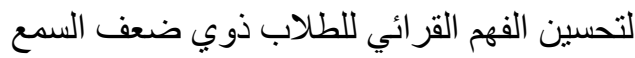
$0.865 \quad 15$ 0.864 30 الثبات العام و اقع توظيف استراتيجية روبنسون لتحسين الفهم القرائي للطلاب

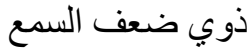
يتضح من الجدول (3) أن معامل ثبات ألفا كرونباخ العام عالٍ، حيث بلغ (0.864)،

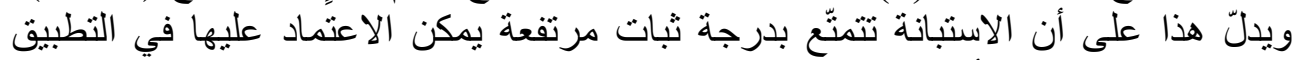

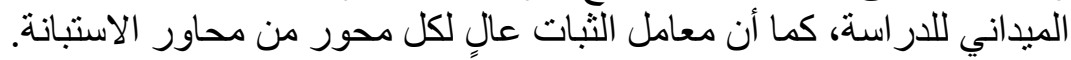
عرض النتائج إجابة السؤال الأول: ما واقع توظيف استراتيجية روبنسون لتحسين الفهم القرائي من قِبل

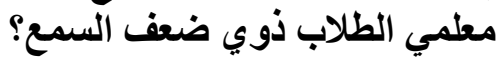

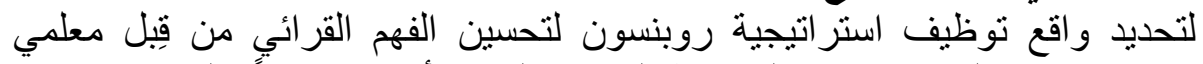

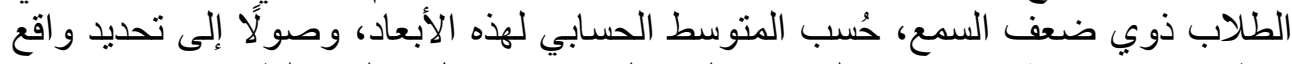

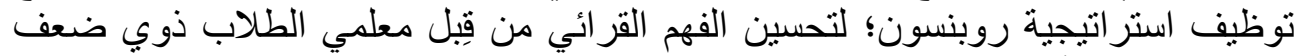

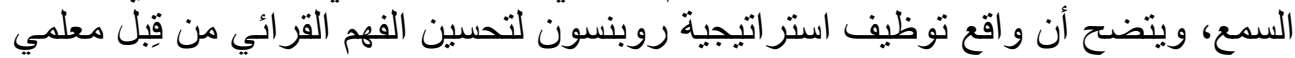

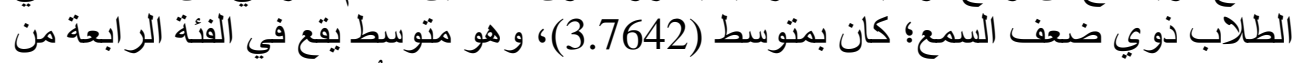

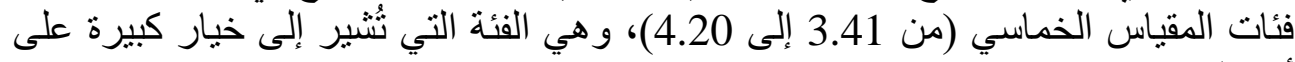

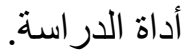

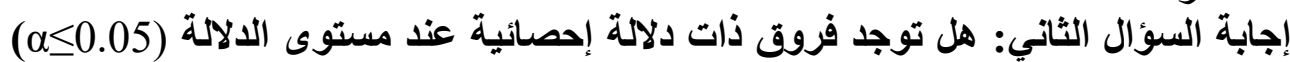

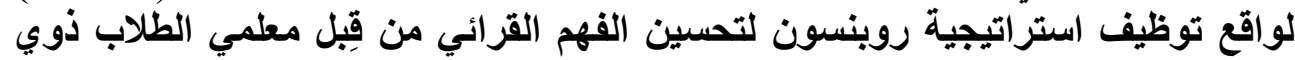

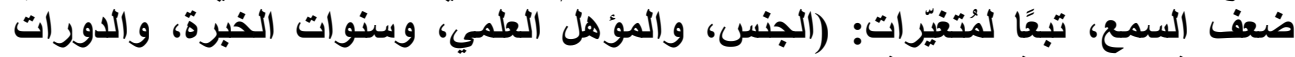

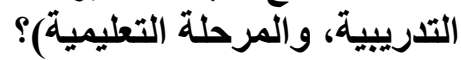
وللإجابة عن هذا السؤال صيغت التعيد الفرضية الآتية: 


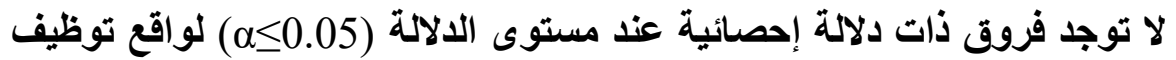

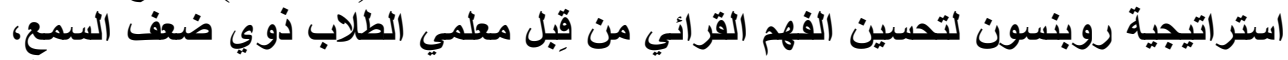

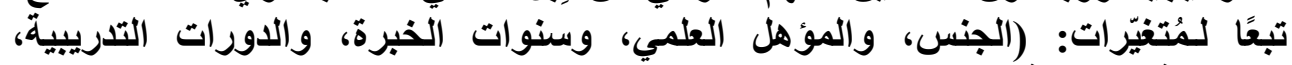
والمرحلة التعليمية).

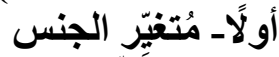

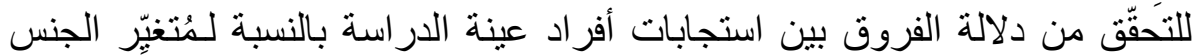

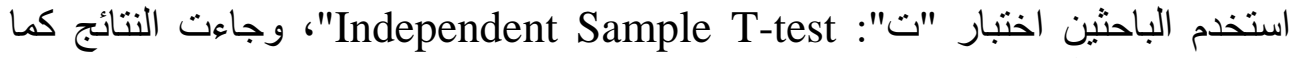
يوضحها الجدول الآتي.

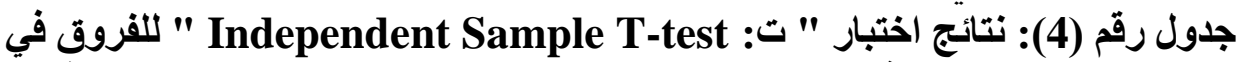
واقع توظيف استراتيجية روبنسون لتحسين الفهم القرائي من قِبل معلمي الطلاب ذوبي

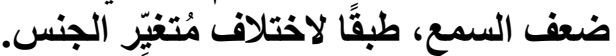

\begin{tabular}{|c|c|c|c|c|c|c|c|}
\hline التعليق & 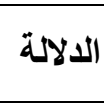 & قيمة ت & المعياري & المتوسط & العدد & الجنس & 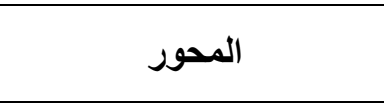 \\
\hline & & & .81660 & 3.6167 & 40 & ذكر & واقع توظيف استراتيجية \\
\hline غالة & 0.145 & 1.467 & .79310 & 3.8510 & 68 & أنتى & 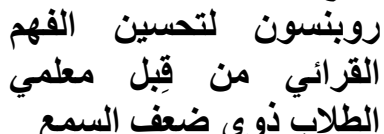 \\
\hline
\end{tabular}

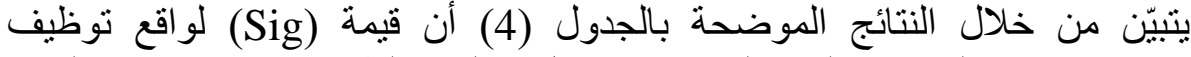

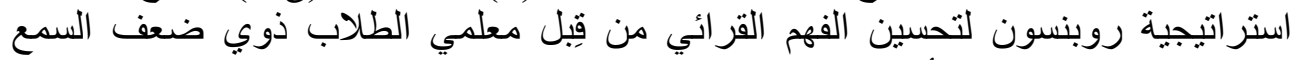

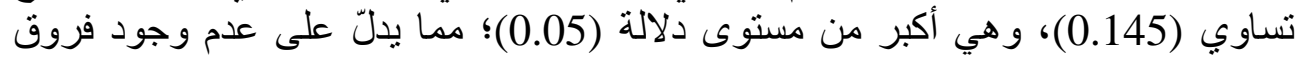

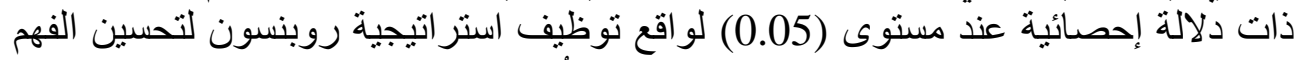

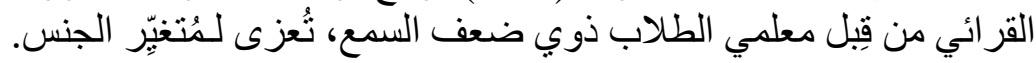

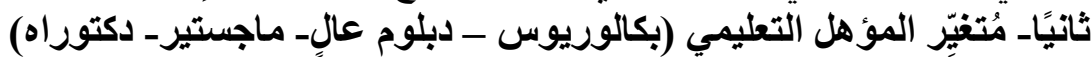

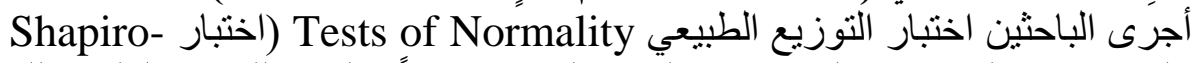
(Wilk

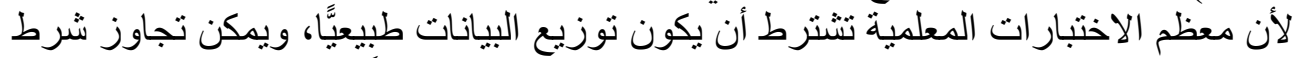

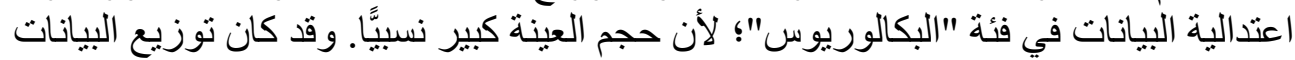

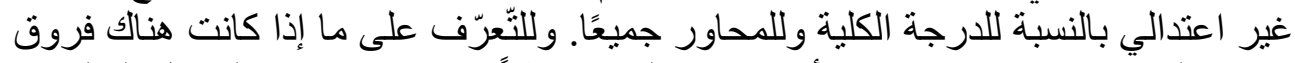

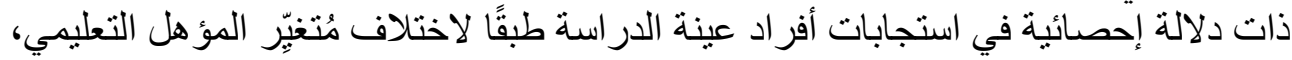

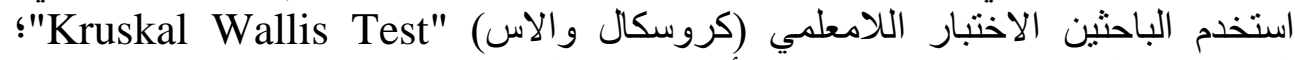
التوضيح دلالة الفروق بين استجابات أفراد عينة الدراسة، وجاء ولاءت الأت النتائج كما يوضحها

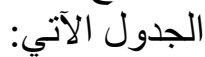


جدول (5). نتائج اختبار "Kruskal Wallis Test" للفروق في واقع توظيف

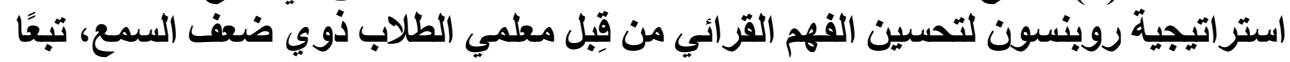

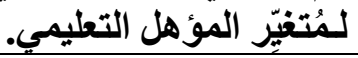

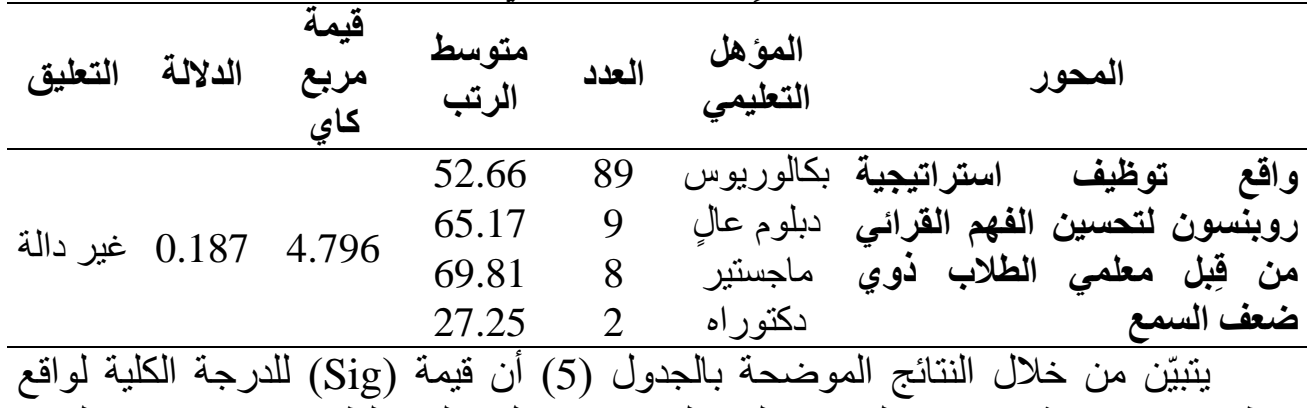

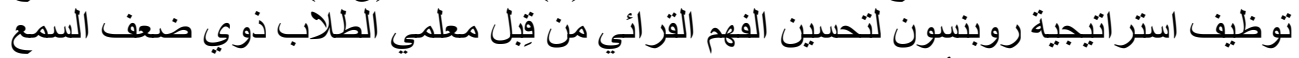

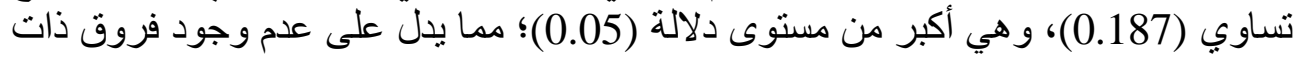

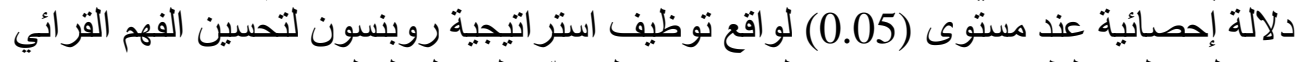

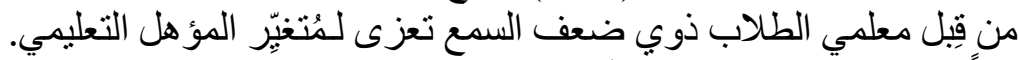

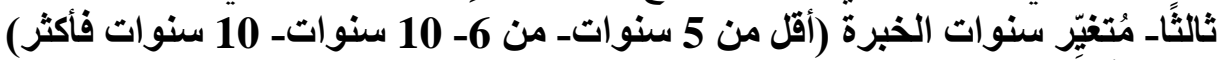

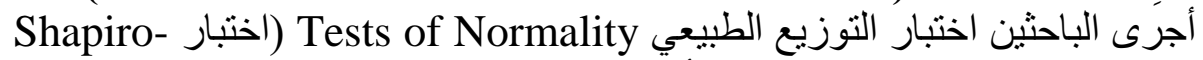

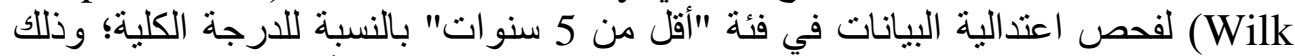

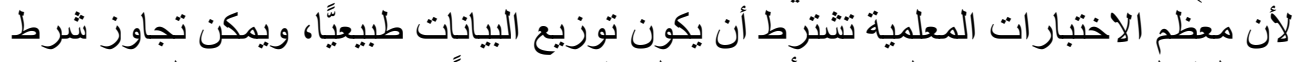

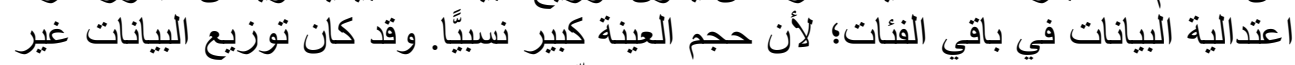

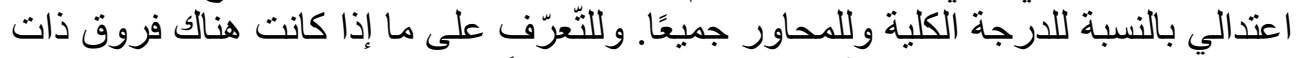

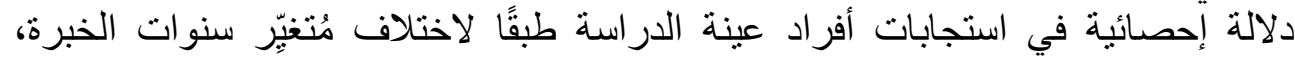

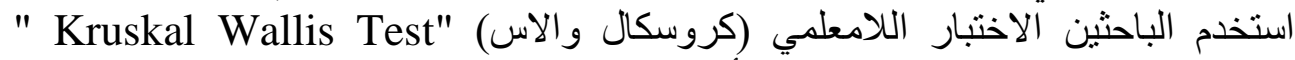

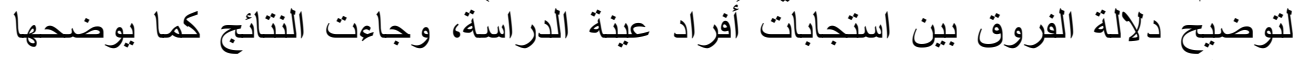

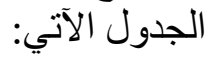

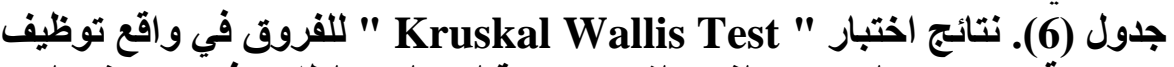

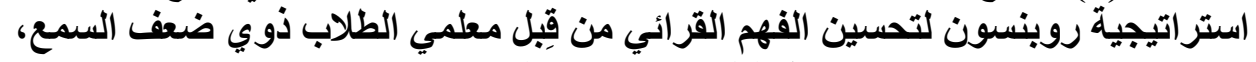

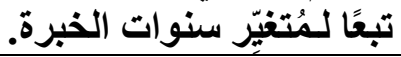

\begin{tabular}{|c|c|c|c|c|c|c|}
\hline التعليق & الدالة & قيمة مريع & مترسط & 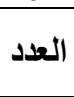 & سنوات الخبرة & المحور \\
\hline \multirow{3}{*}{ غير دالة } & \multirow{3}{*}{0.052} & \multirow{3}{*}{5.712} & 84.50 & 4 & أقل من 5 سنوات & توظيف استر اتيجية \\
\hline & & & 45.35 & 31 & من 6 إلى 10 & 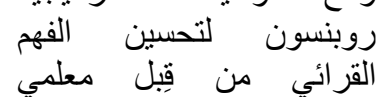 \\
\hline & & & 56.74 & 73 & 10سنو ات فأكثر & الطلاب ذوب ضعف السمع \\
\hline
\end{tabular}


يتضح من نتائج الجدول (6) أن قيمة (Sig) للارجة الكلية لو اقع توظيف استر اتيجية

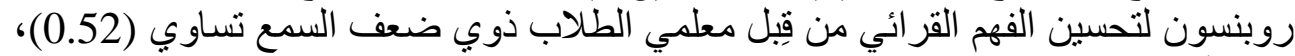

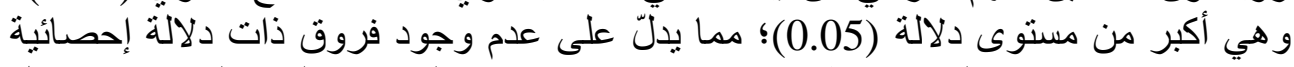

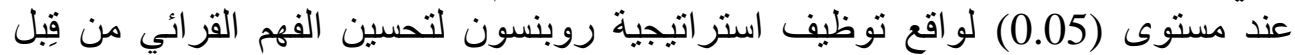

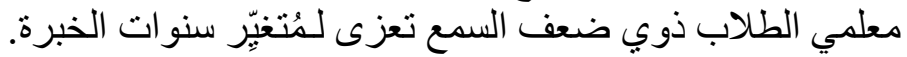

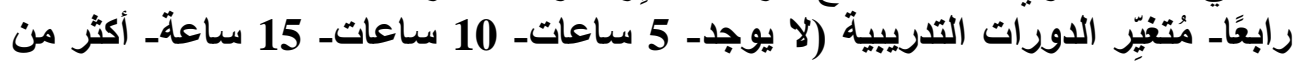

أجرى الباحثين اختبار التوزيع الطبيعي Tests of Normality (اختبار - Shapiro (Wilk

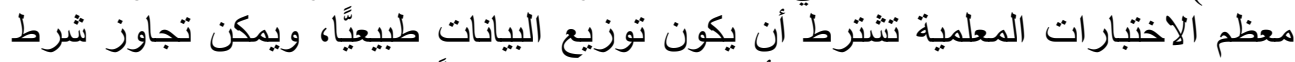

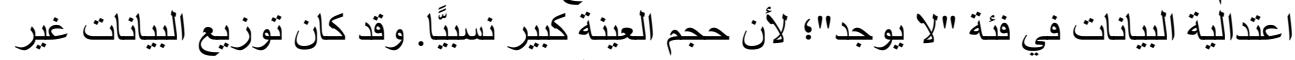

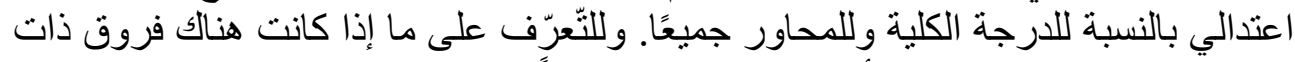

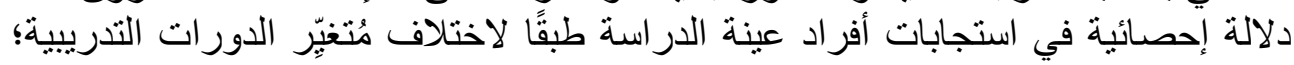

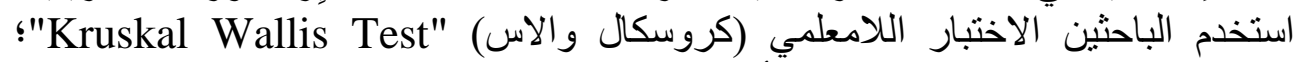

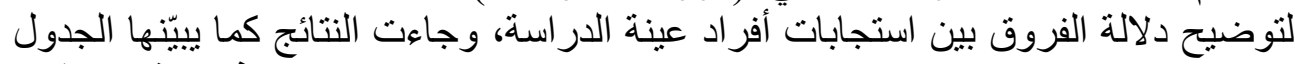

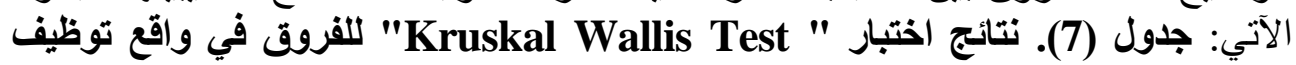

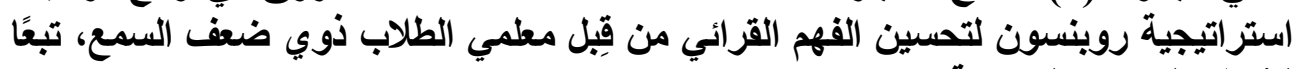

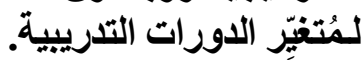

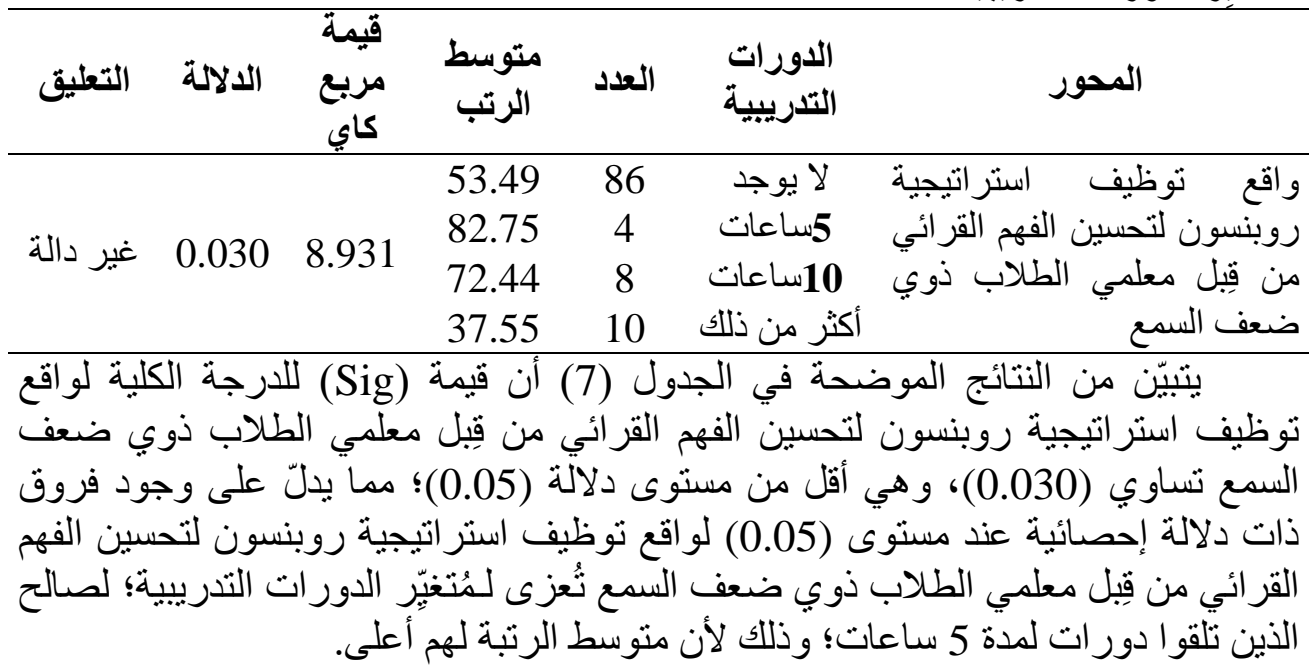


خامسنًا مُتْغِّر المرحلة التعليمية (ابتدائيـ متوسطـ ثنانوي)

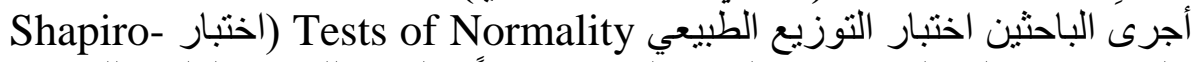

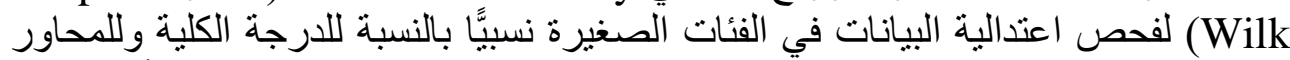

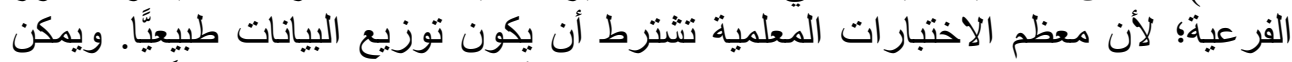

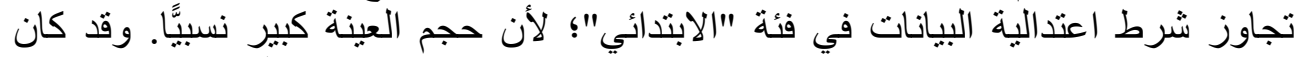

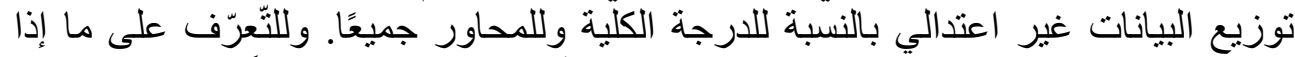

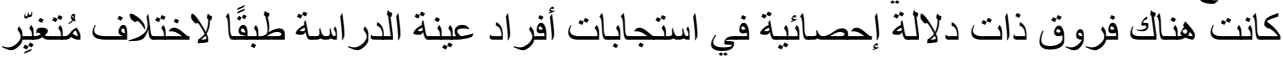

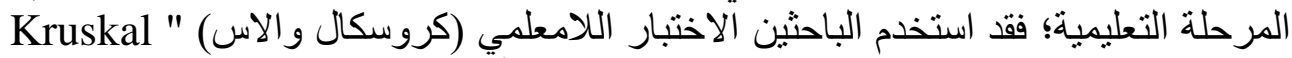
Wallis Test

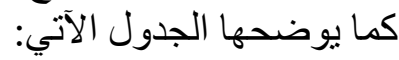

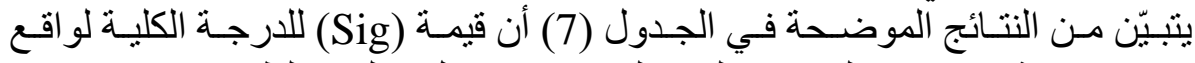

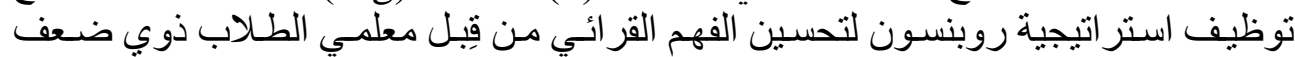

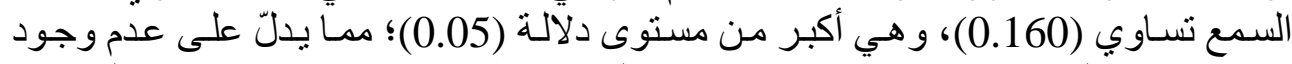

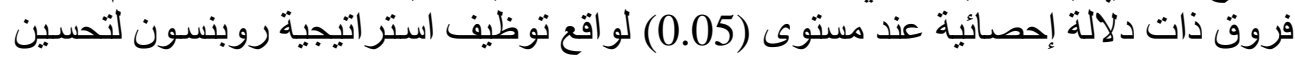

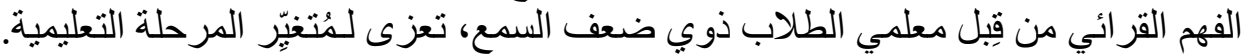

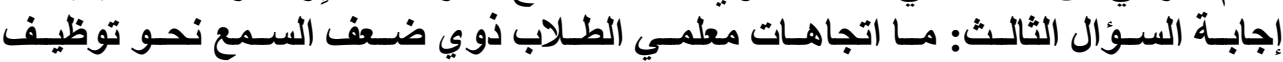
استراتيجية روبنسون لتحسين الفهم القرائي؟ التهاب

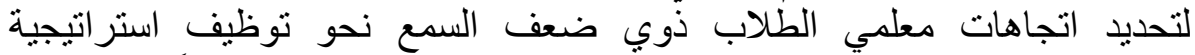

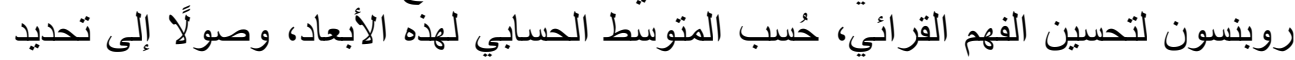

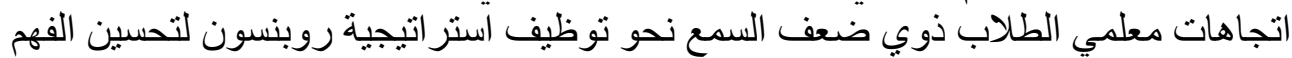

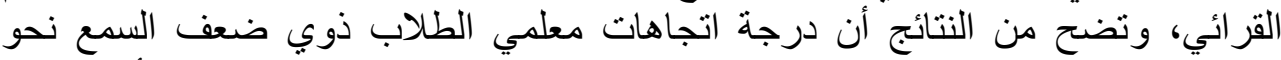

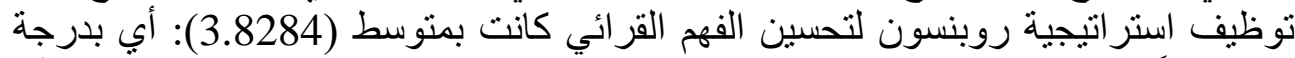

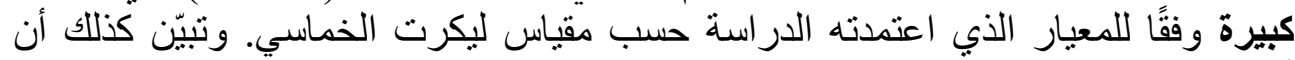

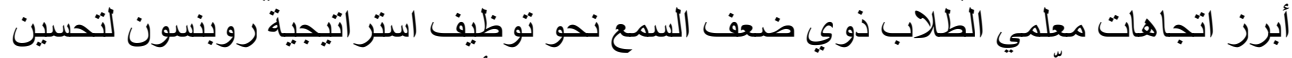

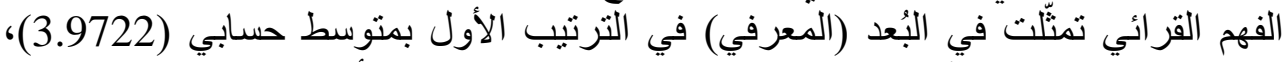

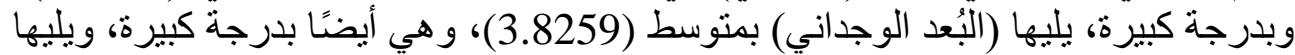

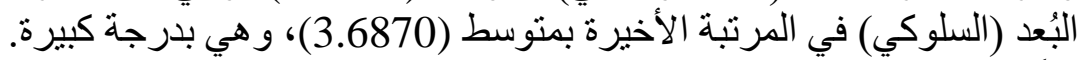

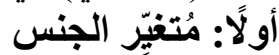
للتحقِّق دلالة الفروق بين استجابات أفر اد عينة الدر اسة بالنسبة لـُتنغيّر الجنس استخدم

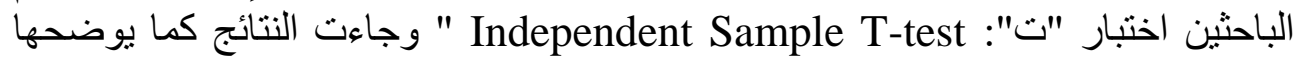
الجدول الآتي: 
جدول (8). نتائج اختبار (ت) (Independent Sample T-test) للقروق في اتجاهات معلمي الطلاب ذوي ضعف السمع نحو توظيف استراتيجية روبنسون لتحسين الفهم القرائي،

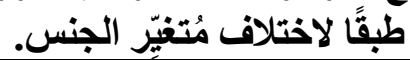

\begin{tabular}{|c|c|c|c|c|c|c|c|}
\hline التعليق & الدلالة & قيمة ت & المعياري & المتوسط & العدد & الجنس الجس & 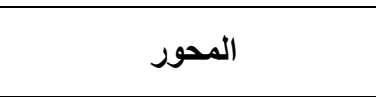 \\
\hline \multirow{2}{*}{ 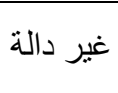 } & & & .86941 & 3.8050 & 40 & ذكر & \\
\hline & 0.095 & 1.683 & .74334 & 4.0706 & 68 & أنثى & روي \\
\hline \multirow{2}{*}{ غير دالة } & 0.493 & 0.658 & .72296 & 3.6200 & 40 & ذَكر & وكى \\
\hline & & & .86034 & 3.7265 & 68 & أنثى & \\
\hline \multirow{3}{*}{ 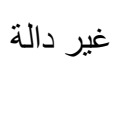 } & 0134 & 1509 & .76701 & 3.6800 & 40 & ذكر & \\
\hline & 0.134 & 1.509 & .77296 & 3.9118 & 68 & أنثى & \\
\hline & & & .73014 & 3.7017 & 40 & ذكر & اتجاهات معلمي الطلاب ذوي \\
\hline 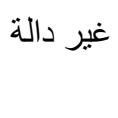 & 0.178 & 1.355 & .75393 & 3.9029 & 68 & & الفهر القيجية روينسئ نحون لتحسين \\
\hline
\end{tabular}

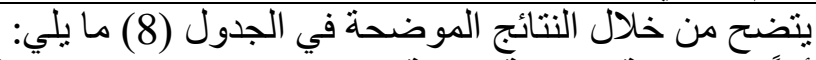

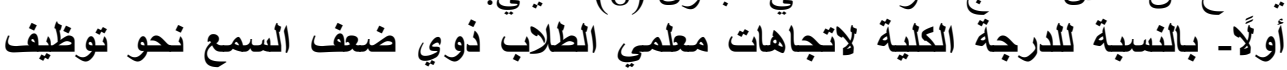

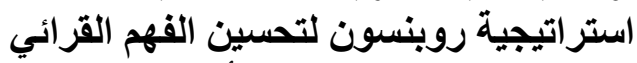

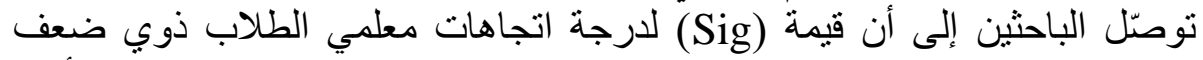

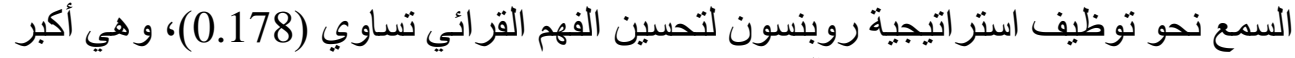

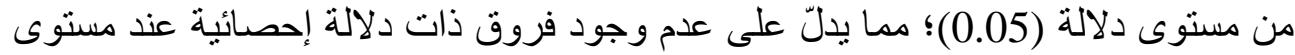

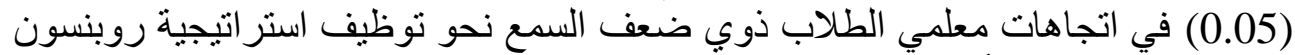

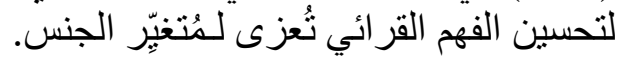
ثانيًا بالنسبة للمجالات الفرعية الفية

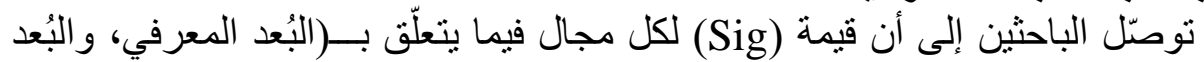

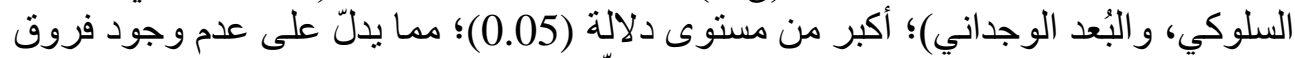

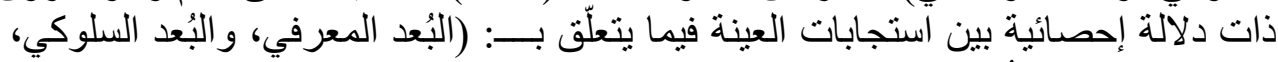

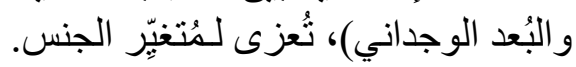

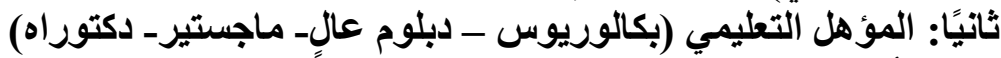
أجرى الباحثين اختبار التوزيع الطبيعي Tests of Normality (Wilk

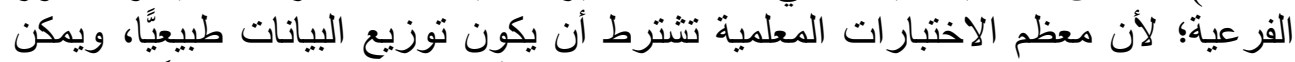

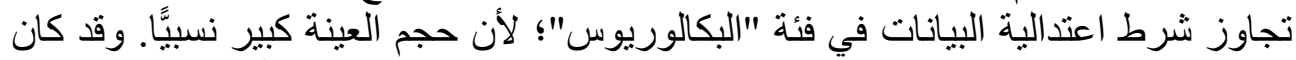

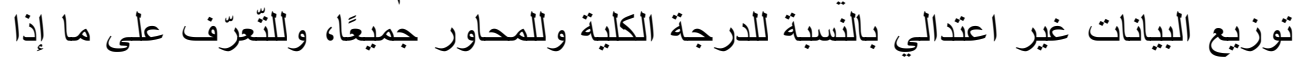


كانت هناك فروق ذات دلالة إحصائية في استجابات أفراد عينة الدر اسة طبقًا لاختلاف مُتنغِّر

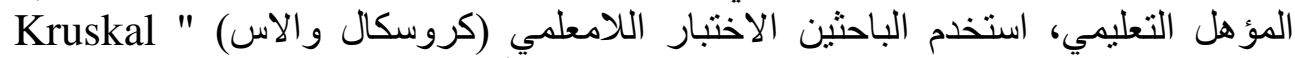
كallis Test كما يوضّحها الجدول الآتي:

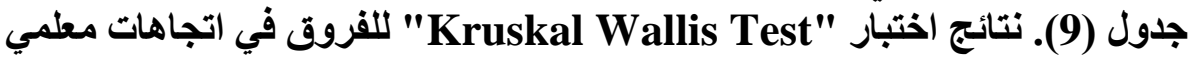
الطلاب ذوي ضعف السمع نحو توظيف استراتيجية روينسون لتحسين الفهم القرائي، تبعًا

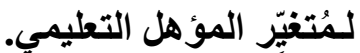

\begin{tabular}{|c|c|c|c|c|c|c|}
\hline التعليق & الدلالة & قريع & الرتب & العدد & التعليمي هل & المحور \\
\hline \multirow{4}{*}{ غير دالة } & \multirow{4}{*}{0.111} & \multirow{4}{*}{6.021} & 51.58 & 89 & بكالوريوس & \multirow{4}{*}{ البُعد المعرفي } \\
\hline & & & 71.72 & 9 & دبلوم عالٍ & \\
\hline & & & 70.69 & 8 & ماجستير & \\
\hline & & & 42.25 & 2 & دكتور اه & \\
\hline \multirow{4}{*}{ غير دالة } & \multirow{4}{*}{0.388} & \multirow{4}{*}{3.025} & 52.39 & 89 & بكالوريوس & \multirow{4}{*}{ البُعد السلوكي } \\
\hline & & & 70.00 & 9 & دبلوم عالٍ & \\
\hline & & & 61.13 & 8 & ماجستير & \\
\hline & & & 52.25 & 2 & دكتور اه & \\
\hline \multirow{4}{*}{ غير دالة } & \multirow{4}{*}{0.368} & \multirow{4}{*}{3.157} & 54.20 & 89 & بكالوريوس & \multirow{4}{*}{ البُعد الوجداني } \\
\hline & & & 67.67 & 9 & دبلوم عالٍ & \\
\hline & & & 49.25 & 8 & ماجستير & \\
\hline & & & 29.50 & 2 & دكتور اه & \\
\hline \multirow{3}{*}{ غير دالة } & \multirow{3}{*}{0.294} & \multirow{3}{*}{3.714} & 52.42 & 89 & بكالوريوس & \multirow{3}{*}{ 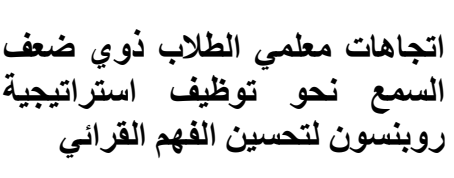 } \\
\hline & & & $\begin{array}{l}70.44 \\
63.13\end{array}$ & $\begin{array}{l}9 \\
8\end{array}$ & داجستنيرٍ & \\
\hline & & & 41.00 & 2 & دكتور اه & \\
\hline
\end{tabular}

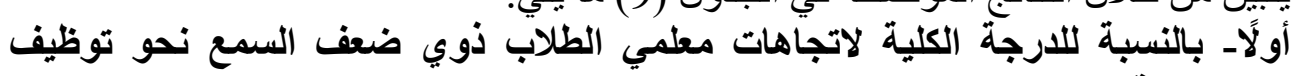

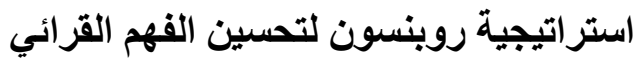

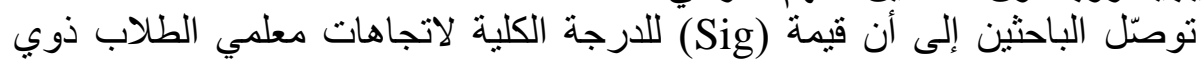

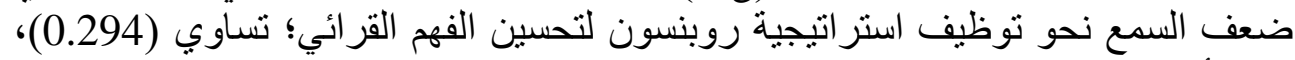

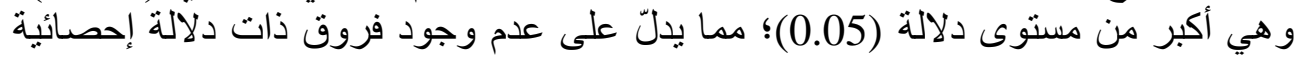

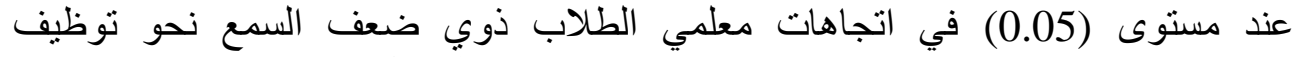

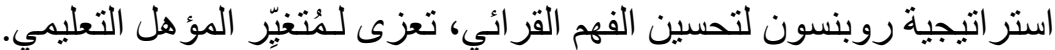

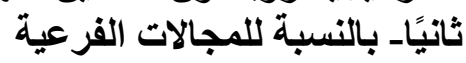


توصّل الباحثين إلى أن قيمة (Sig) لكل مجال فيما يتعلّق بـــ(البُعد المعرفي، و البُعد

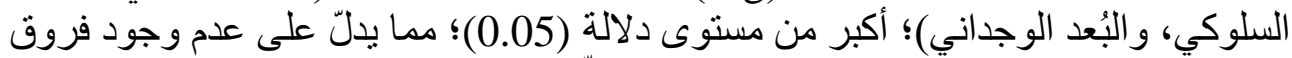

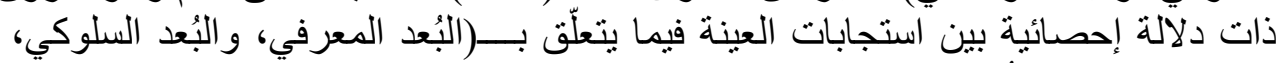

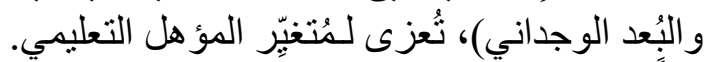

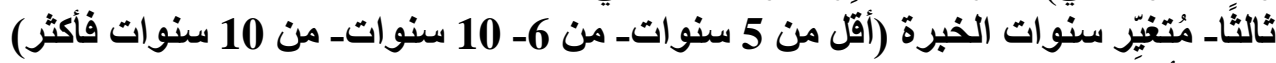

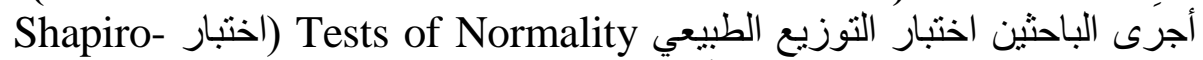

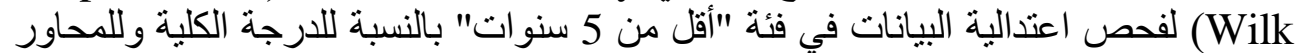

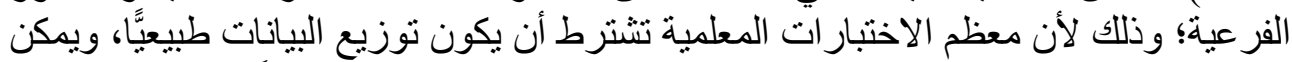

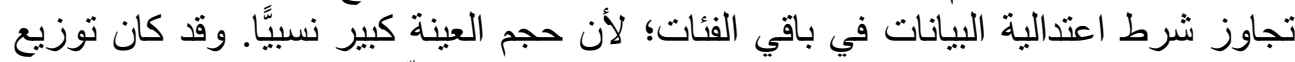

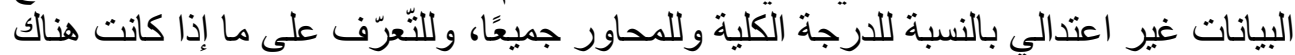

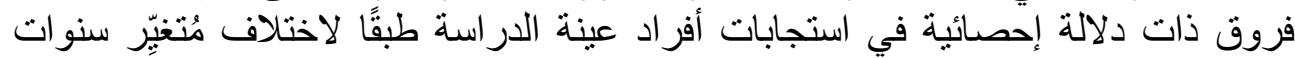

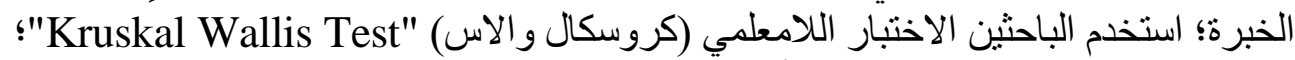
التوضيح دلالة الفروق بين استجابات أفر اد عينة الدر استة، وجاءت الأت النتائج كما يوضحها الجدول الآتي: جذول (10). نتائج اختبار " Kruskal Wallis Test " للفروف في اتجاهات معلمي الطلاب ذوي ضعف السمع نحو توظيف استراتيجية روبنسون لتحسين الفهم القرائي، تبعًا لـمُتخيّر سنوات الخبرة.

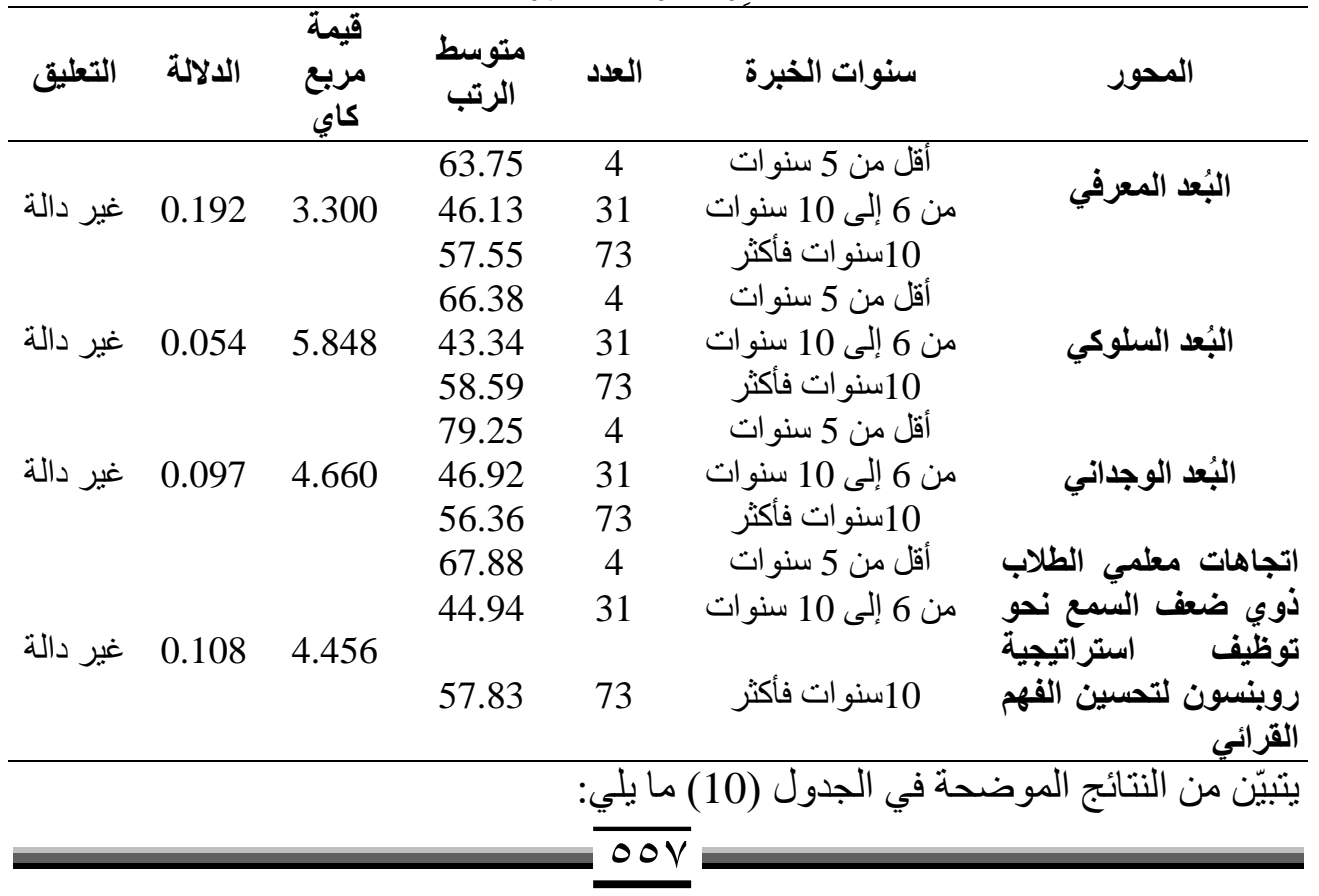


أولًا- بالنسبة للارجة الكلية لاتجاهات معلمي الطلاب ذوي ضعف السمع نحو توظيف

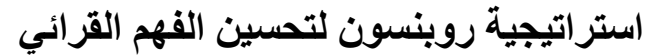

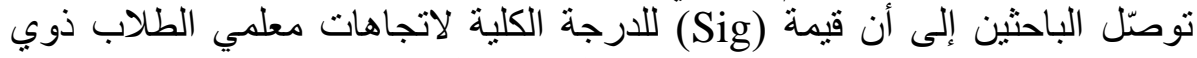

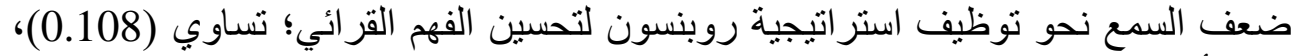

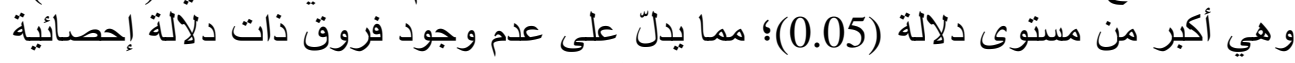

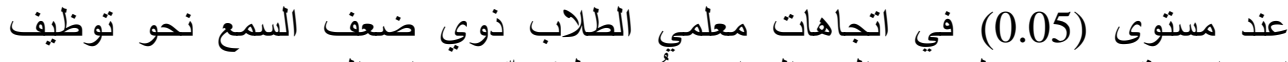

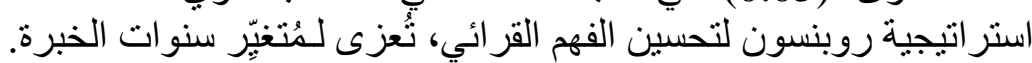

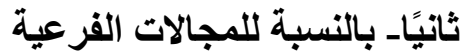

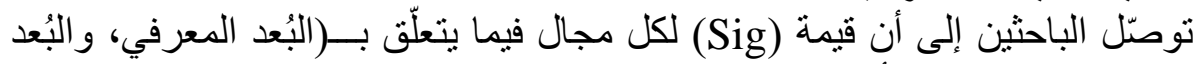

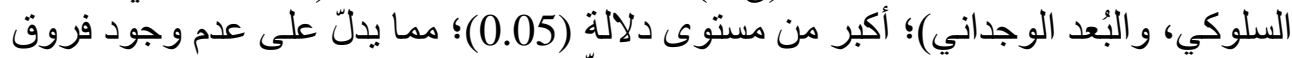

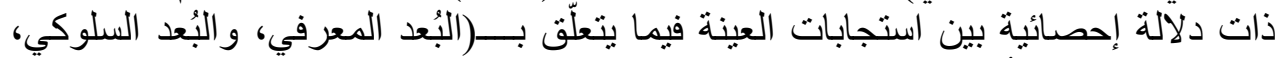

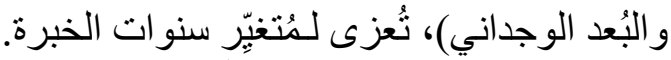

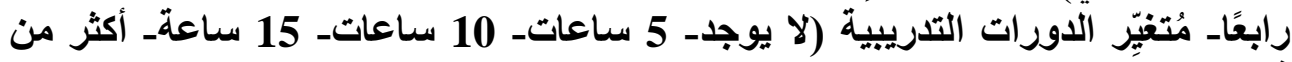
ذلإن

أجرى الباحثين التوزيع الطبيعي Tests of Normality (اختبار Shapiro-Wilk)

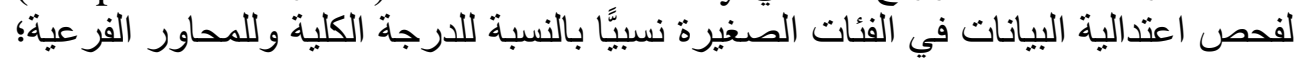

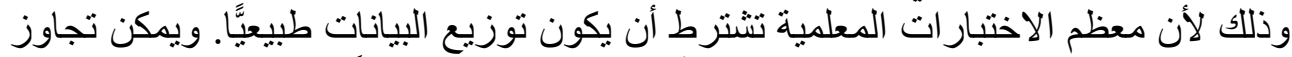

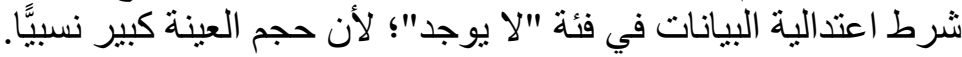

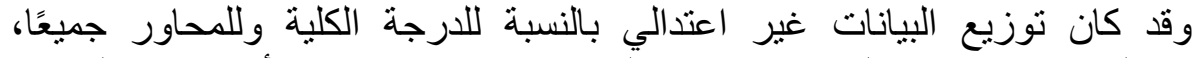

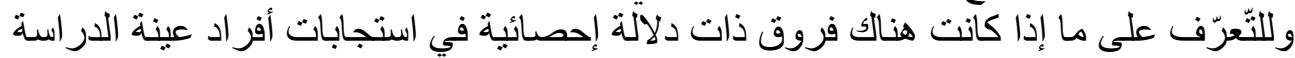

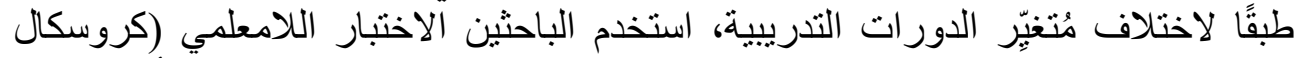

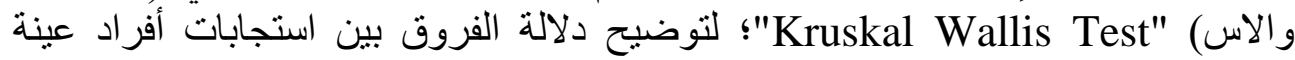
الدراسة، وجاءت النتائج كما يوضحها الجدول الآتي: داتي:

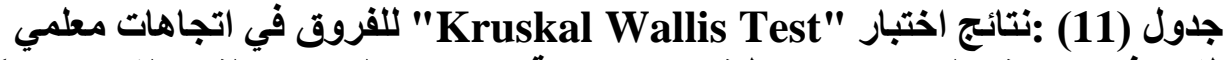
الطلاب ذوي ضعف السمع نحو توظيف استراتيجية روبنسون لتحسين الفهم القرائي، تبعًا لـمُتفيّر الدورات التدريبية.

\begin{tabular}{|c|c|c|c|c|c|c|}
\hline التعليق & الدلالة & كريعة & متوسط الرتب & العدد & التدريبية & المحور \\
\hline \multirow{3}{*}{ غير دالة } & & & 54.81 & 86 & لا يوجد & \multirow{3}{*}{ البُعد المعرفي } \\
\hline & 0.175 & 4.954 & 59.50 & 4 & 5ساعات & \\
\hline & & & 69.69 & 8 & 10ساعات & \\
\hline
\end{tabular}




\section{المجلد الخامس - ع (N) أكتوبر ابrمA}

\begin{tabular}{|c|c|c|c|c|c|c|}
\hline التعليق & الدلالة & كريع & متوسط الرتب & العدد & التاريبية & المحور \\
\hline \multirow{5}{*}{ غير دالة } & \multirow{5}{*}{0.711} & \multirow{5}{*}{1.378} & 37.65 & 10 & أكثر من ذلك & \multirow{6}{*}{ البُعد السلوكي } \\
\hline & & & 55.05 & 86 & لا يوجد & \\
\hline & & & 53.75 & 4 & 5ساعات & \\
\hline & & & 61.13 & 8 & 10ساعات & \\
\hline & & & 44.75 & 10 & أكثر من ذلك & \\
\hline \multirow{4}{*}{ غير دالة } & \multirow{4}{*}{0.404} & \multirow{4}{*}{2.919} & 54.43 & 86 & لا يوجد & \\
\hline & & & 71.25 & 4 & 5ساعات & \multirow{3}{*}{ البُعد الوجداني } \\
\hline & & & 61.25 & 8 & 10ساعات & \\
\hline & & & 43.00 & 10 & أكثر من ذلك & \\
\hline \multirow{4}{*}{ غير دالة } & \multirow{4}{*}{0.267} & \multirow{4}{*}{3.948} & 54.57 & 86 & لا يوجد & \multirow{4}{*}{ 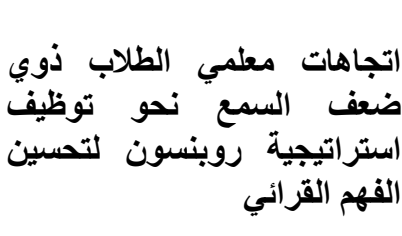 } \\
\hline & & & 62.13 & 4 & 5ساعات & \\
\hline & & & 68.19 & 8 & 10ساعات & \\
\hline & & & 39.90 & 10 & أكثر من ذلك & \\
\hline
\end{tabular}

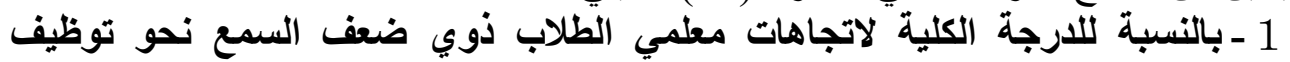

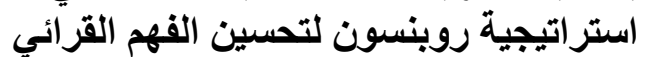

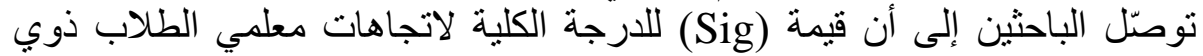

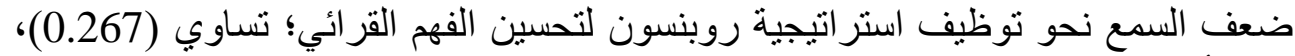

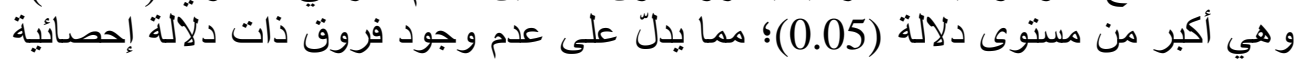

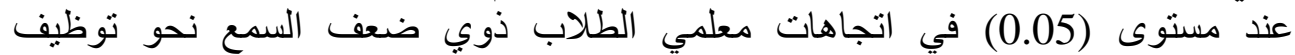

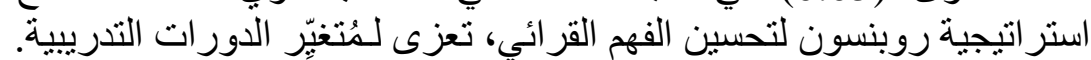

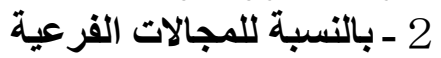

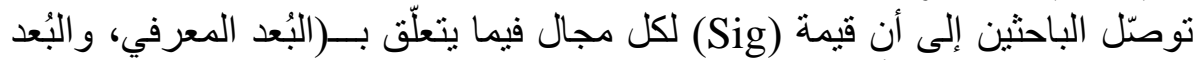

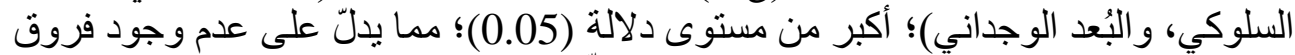

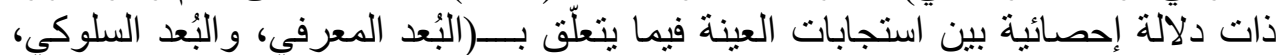

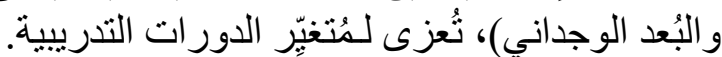

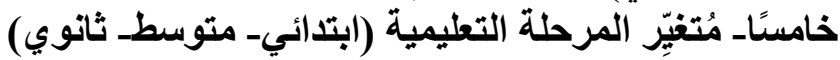




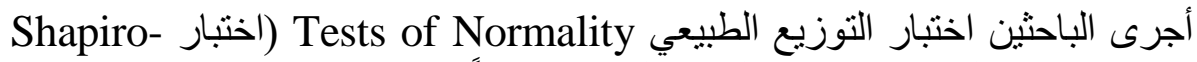

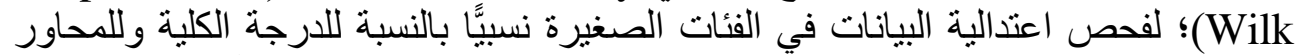

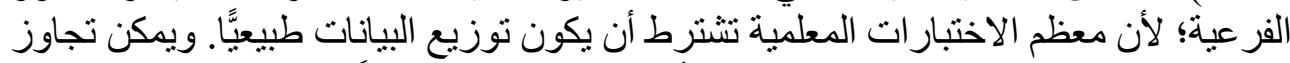

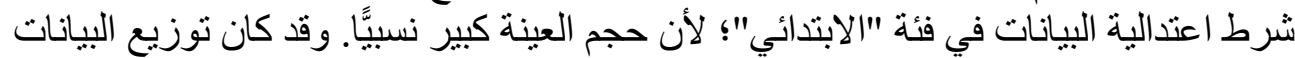

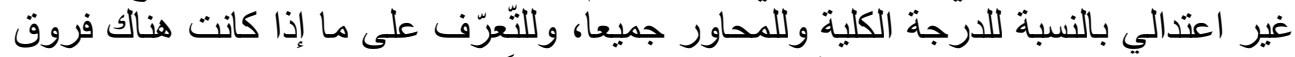

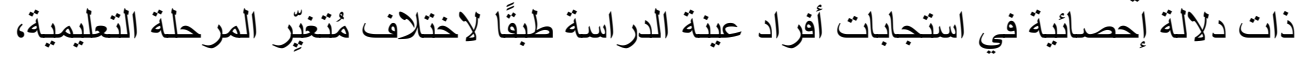

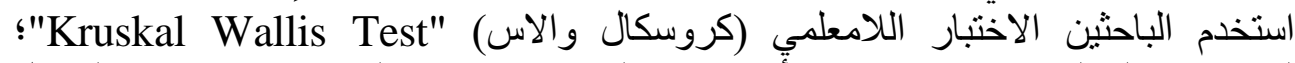
التوضيح دلالة الفروق بين استجابات أُفر اد عينة الدر اسة، والأل وجاءت النتائج كما يوضحها الجدول الآتي:

جدول (12): نتائج اختبار " Kruskal Wallis Test" للفروق في اتجاهات معلمي الطلاب ذوي ضعف السمع نحو توظيف استراتيجية روبنسون لتحسين الفهم القرائي، تبعًا

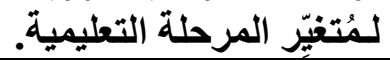

\begin{tabular}{|c|c|c|c|c|c|c|}
\hline التعليق & الدلالة الدالة & كريعة & متوسط & العدد & التعليمية & 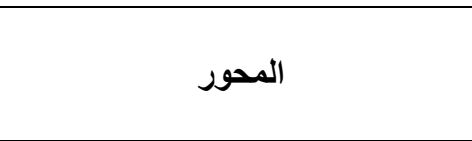 \\
\hline \multirow{4}{*}{ غير دالة } & & & 51.61 & 73 & ابتدائي & \\
\hline & 0.161 & 3.656 & 71.40 & 10 & منوسطّ & 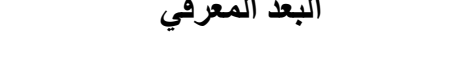 \\
\hline & & & 56.18 & 25 & ثانوي & \\
\hline & & & 51.45 & 73 & ابتدائي & \\
\hline \multirow[t]{3}{*}{ غير دالة } & 0.083 & 4.990 & 74.80 & 10 & متوسط & البُعد السلوكي \\
\hline & & & 55.30 & 25 & ثانوي & \\
\hline & & & 51.72 & 73 & ابتدائي & \\
\hline \multirow[t]{3}{*}{ 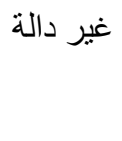 } & 0.239 & 2.861 & 68.80 & 10 & متوسط & البُعد الوجداني \\
\hline & & & 56.90 & 25 & ثانوي & \\
\hline & & & 51.44 & 73 & 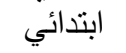 & اتجاهات معلمي الطلاب ذوي ضعف \\
\hline \multirow[t]{2}{*}{ 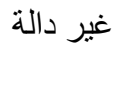 } & 0.106 & 4.489 & 73.65 & 10 & منوسط & السمع نحو "توظيف استراتيجية \\
\hline & & & 55.78 & 25 & ثانوي & روبنسون لتحسين الفهم القرائي \\
\hline
\end{tabular}

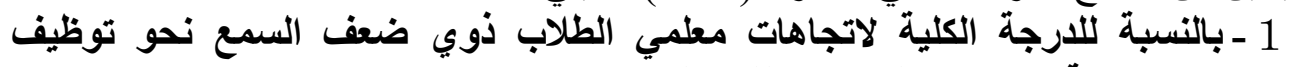

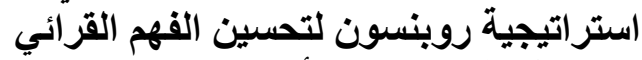

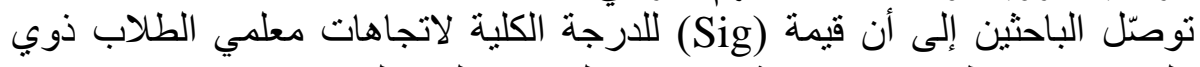

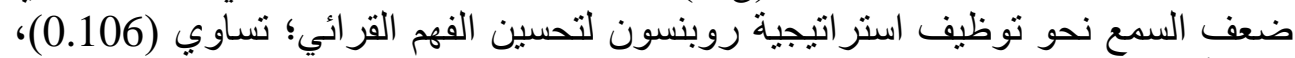

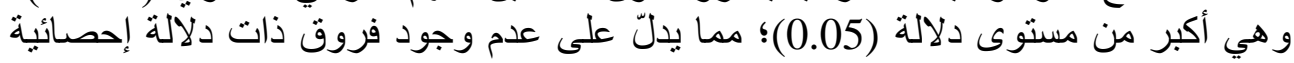

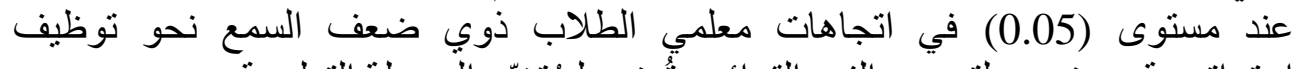

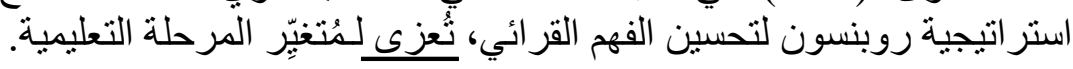




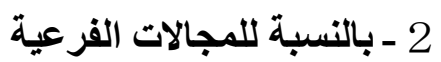

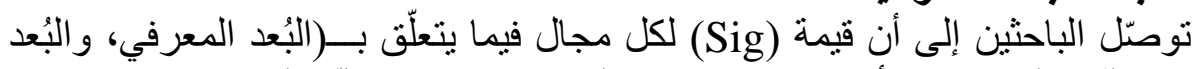

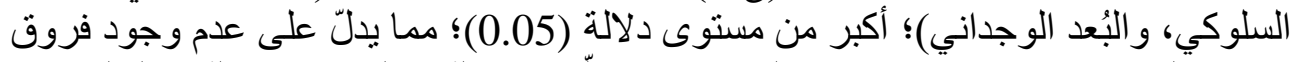

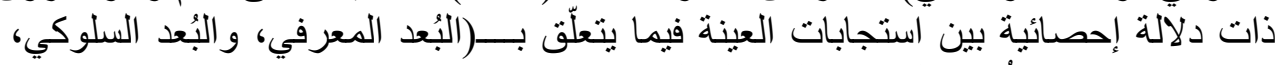

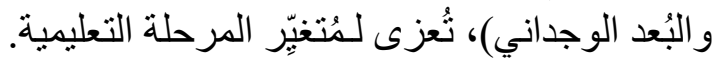


إبراهيم، سليمان عبدالواحد. (2013). صعوبات الفهم القرائسي لذوي المشكلات التعليمبة.

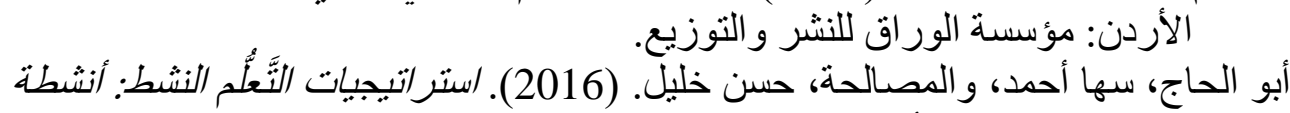

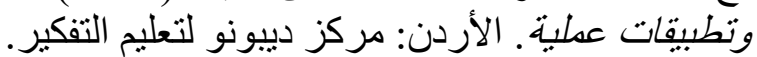

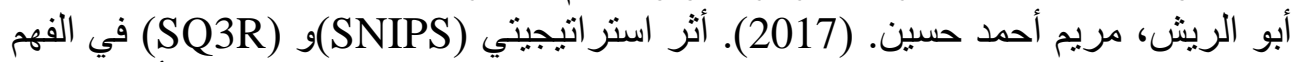

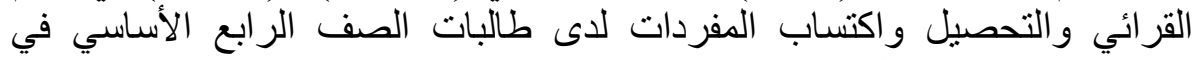
DOI: لفطين. دراسات العلوم التربوية، 10.35516/0102-044-991-008 أبو النور، محمد عبد التواب، وعبد الفتاح، آمال جمعة. (2019). استراتيجيات التدريب

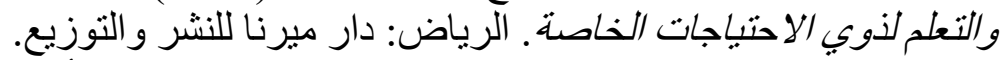

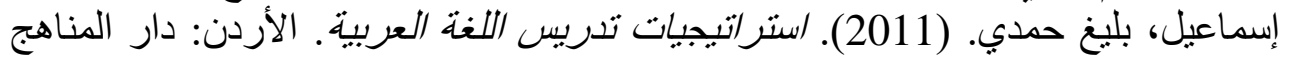
للنشر والتوزيع. مئي. الأشرم، شادي منير. (2016). أثر استراتيجية روبنسون (SQ3R) في تندية التحصيل

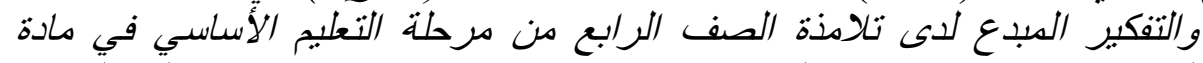

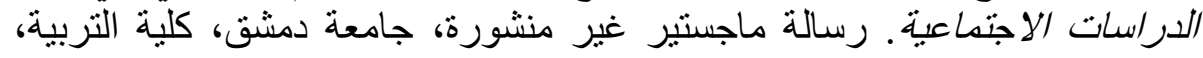

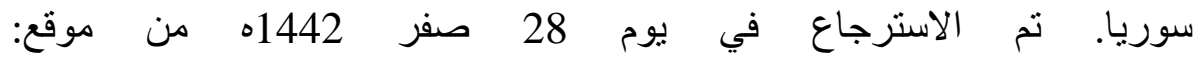
http://search.shamaa.org/FullRecord?ID=242693 البطش، محمد وليد، وأبو زينة، فريد كامل. (2007). مناهج البحث العلدي: تصديم البحث

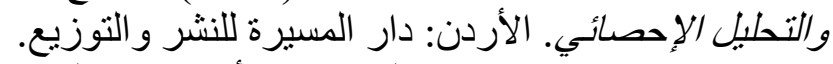

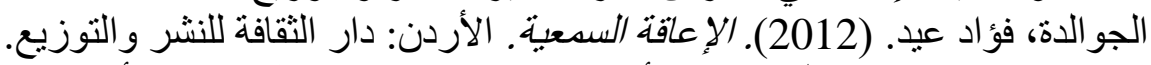

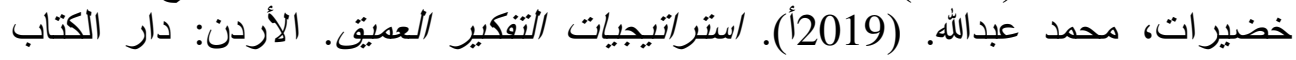
الثقافي. خضير ات، محمد عبدالله (2019ب). استراتيجيات التفكبر المبتامعرفية: نماذج وتطبيقات في التدريس. إربد، الأردن: دار الكتاب التقافي. زايد، فهد خليل. (2010). الأساليب العصرية في العي تدربيس اللغة العربية. الأردن: دار يافا

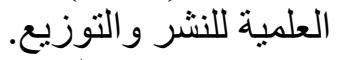

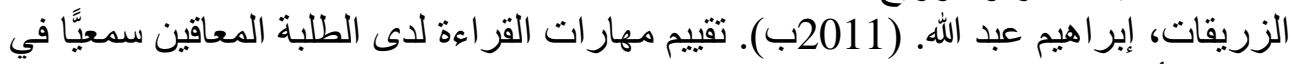

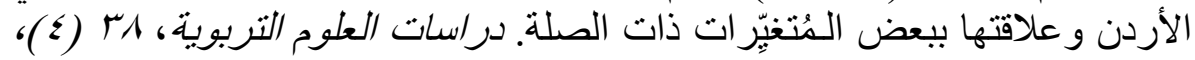
1276- 1292. التعريف الرقمي للمرجع: -076-10.35516/0102-038-998

076 
الزريقات، إبراهيم عبدالله (2011أ). الإعاقة السمعية: مبادئ التأهيل السدعي والكلامي

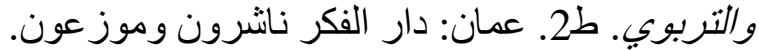

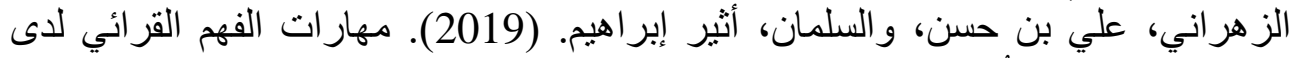

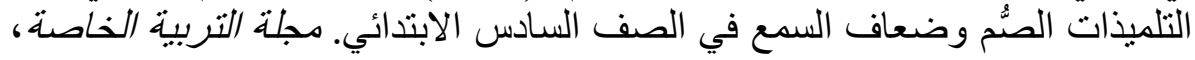
61- 94 https://dx.doi.org/10.21608/sero.2019.91264، 9 شاكر، مها شفيق. (2011). أثر استر/تيجيتي روبنسون الأصلية والمطورة في تنمبية

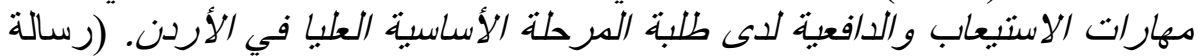

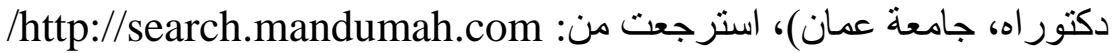

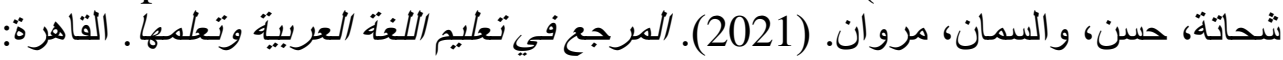
مكتبة الدار العربية للكتاب. الشهراني، محمد مبارك، اليامي، رفعة هادي (2020). الملدخل إلى فلسفة ومعايير البحوث التوبوية. الأردن: دار اليازوري. شيتز، نانسي. (2015). تعليم الصُّم في القرن الحاري. الحادي والعشربن (ترجمة طارق الريس).

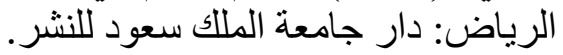

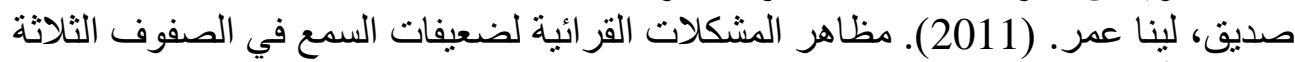

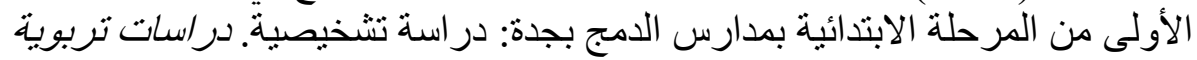

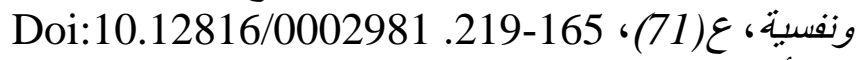

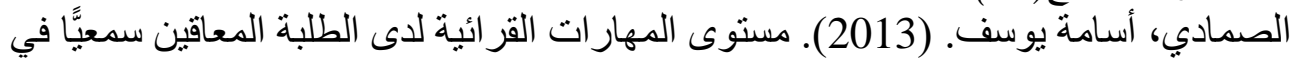

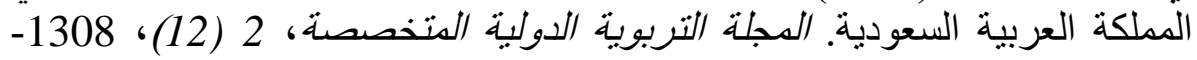
1295. https://search.mandumah.com/Record/842688 الظاهر، زكي محمد. (1999/1269). مبادئ القباس والتقويم في التربية. الأردن: مكتبة الثقافة.

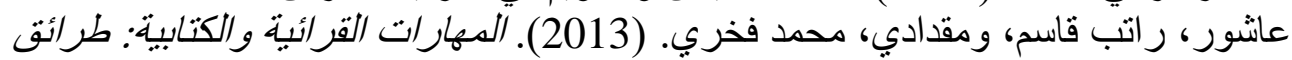

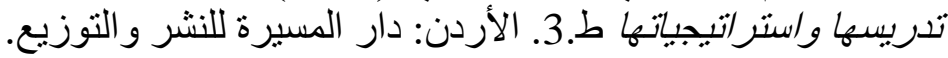

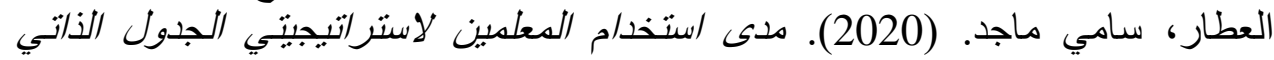
(KWL)

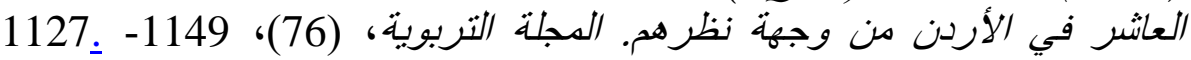

DOI:10.12816/Edvsohag.2020.10.3372. عطية، محسن علي. (2014). استر/تيجيات ما وراء الدعرفة: في فهم الدقروء. الأردن: دار

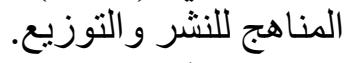
عفانة، عزو، ونشوان، تيسير. (2016). اتجاهات حديثة في القياس والتقويم التربوي. فلسطين: مكتبة سمير منصور للنشر والتوزيع. 
العثمان، عبدالعزيز عبدالله (2021). تطوير مهار ات القراءة و الكتابة البكرة لاى الاطفال الصم. جامعة المجمعة: مكتبة جامعة المجمعة.

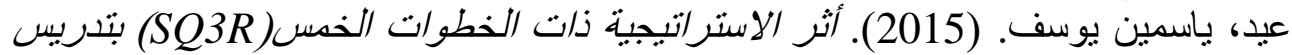

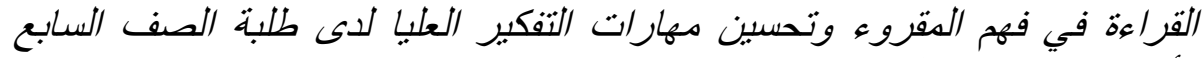

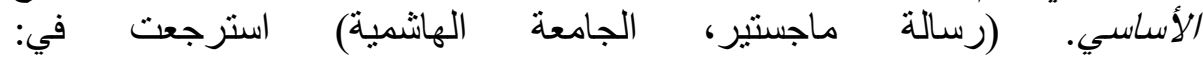
/http://search.mandumah.com

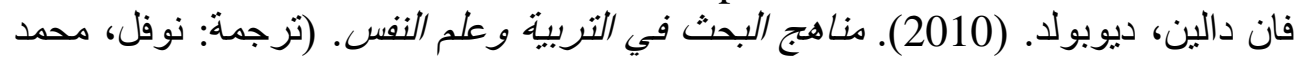

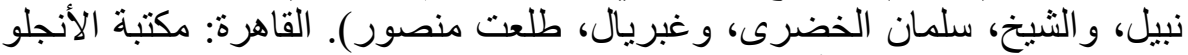

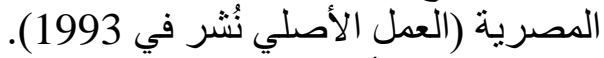

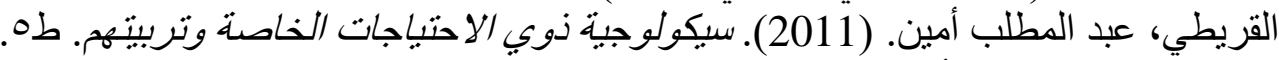
القاهرة: مكتبة الأنجلو المصرية المبن.

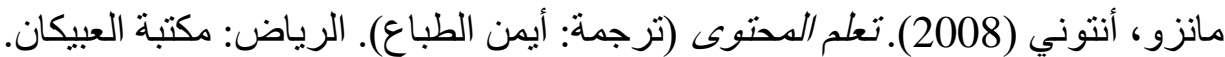

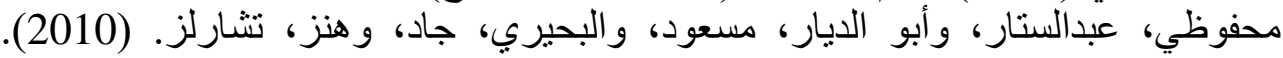

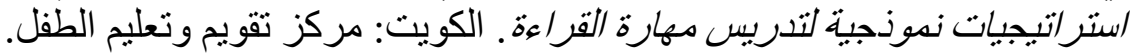

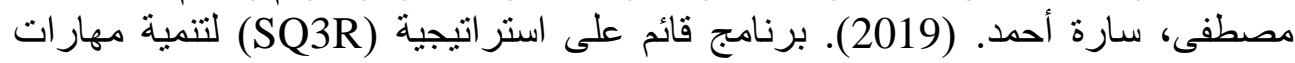

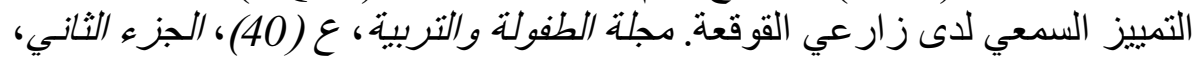
260-191

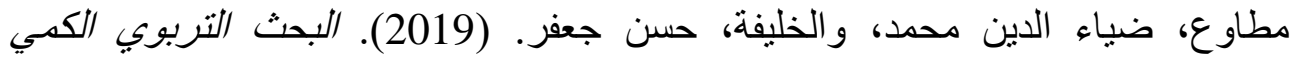

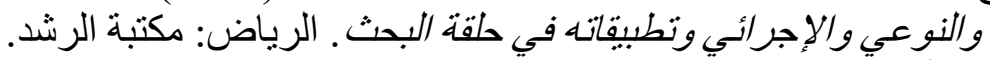

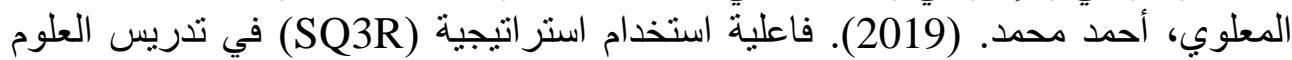

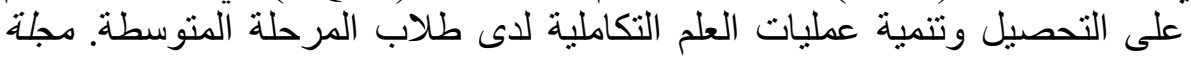

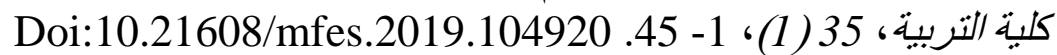

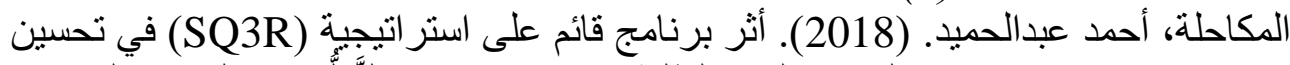

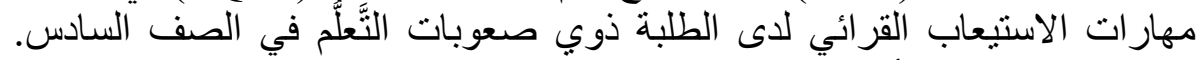

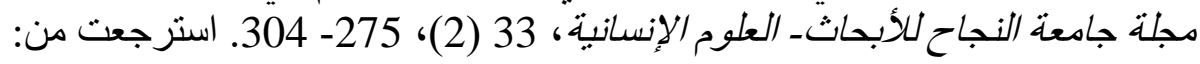
/http://search.mandumah.com https://www.stats.gov.sa الهيئة العامة للإحصاء. (2017). مستح ذوي الإعاقة

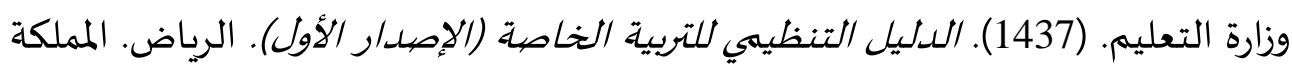
العربية السعودية. 
Anjuni,G., \& Cahyadi, R. (2019). Improving Student's Reading Comprehension Through SQ3R (Survey, Question, Recite and Review) Technique. Project Professional Journal of English Education, 2(1), 1-6. DOI: http://dx.doi.org/10.22460/project.v2i1.p1-6

Avramidis, E. and Norwich, B. (2002). Mainstream teachers' attitudes towards inclusion/integration: a review of the literature. European Journal of Special Educational Needs, 17(2), 129-147.

Baier, K. (2011). The Effects of SQ3R on Fifth Grade Students' Comprehension Levels Master's thesis, Graduate of Bowling Green, Stat University. Retrieved from: https://www.pdfdrive.com/the-effects-of-sq3r-on-fifthgrade-students-kylie-baier-e54018808.html

Easterbrooks, S., \& Stephenson, B. (2006). An examination of twenty literacy, science, and mathematics practices used to educate students who are deaf or hard of hearing. American Annals of the Deaf, 15i (F), 385-397 .

Bavelier, D., \& Neville, H. (2002). Cross-modal plasticity:

Where and how?. Nature Review Neuroscience, 3, 443 452.

Fishbein, M., \& Ajzen, I. (1975). Belief, attitude, intention, and behaviour: An introduction to theory and research. Reading, MA: Addison-Wesley.

Heward, W. (2006). Exceptional children: An introduction to special education. Upper Saddle Rivver: Memill \& Prentice Hall.

Knoors, H., \& Marschark, M. (2014). Teaching Deaf Learning: Psychological and Developmental. New York: Oxford University press. 
Likert, R .(1932). A technique for the measurement of attitudes. Archives of Psychology. 22 (140). 1-55.

Long, G., \& Beil, D. (2005). The importance of direct communication during continuing education workshops for deaf and hard-of-hearing professionals. Journal of Postsecondary Education and Disability, 18, 5-11

Erting, C., Marschark, M., \& Spencer, P. (2000). The deaf child in the family and at school (Eds.). Lawrence Erlbaum Associates.

Marschark, M., \& Hauser, P. (2008). Deaf Cognition Foundations and Outcomes. New York: Oxford University Press.

Marschark, M., and Wauters, L. (2003). Cognitive functioning in deaf adults and children. Oxford handbook of deaf studies, language, and education, 1: 486-499.

Mohay, H. (1999). Language in sight: Mothers' strategies for making language visually accessible to deaf children. In The deaf child in the family and at school (pp. 171-186). Psychology Press.

Moores, D., \& Martin, D. (2006). Deaf Learns Developments in

Curriculum and Instruction. Washington: Library of Congress Cataloging-in- Publication Data.

National Reading Panel. (2000). Report of the National Reading Panel: Teaching children to read - An evidence-based assessment of the scientific research literature on reading and its implications for reading instruction. Jessup, MD: National Institute for Literacy at EDPubs.

Nelson, K. (2004). Commentary. The future of ToM lies in CoM. International Society for the Study of Behavioural Development Newsletter, 45, 16-17. 
Nelson, N., \& Crumpton. T. (2015). Reading, Writing and Spoken language Assessment profiles for student who are deaf and hard of hearing compared with students with language learning disabilities. Journal topics in language disorders, $\quad 35 \quad$ (2), 179.

Doi:http://dx.doi.org/10.1097/TLD.0000000000000055

Neville, H., \& Lawson, D. (1987). Attention to central and peripheral visual space in a movement detection task: An event-related potential and behavioral study. II.

Congenitally deaf adults. Brain Research, 405, 268-283.

Nikkhou,S., Hasanzadeh, S., \& Afrooz, G. (2012). The

Comparative study of reading comprehension in normal hearing and hearing-loss student. Medical Journal of The Islamic Republic of Iran, 21 (2), 71-77. Retrieved from http://mjiri.iums.ac.ir/

Paul, P. (2009). Language and deafness $\left(4^{\text {th }}\right.$ ed,). Boston: Jones and Bartlett.

Proksch, J., \& Bavelier, D. (2002). Changes in the spatial distribution of visual attention after early deafness. Journal of Cognitive Neuroscience, 14(5), 687-701.

Scheetz, N. (2012). Deaf education in the 21st century: topics and trends. Pearson Higher Ed.

Schirmer, B. R. (2001). Psychological, social, and educational dimensions of deafness. Boston: Allyn \& Bacon.

Smolen, E., Hartman, M., \& Wang. Y. (2020). Reading achievement in children with hearing loss who use listening and spoking language: results and implications from 2- year study. Perspectives of the ASHA special interest groups, 5 (6), 1380-1387. Doi: https://doi.org/10.1044/2020 PERSP20-10006. 
Swisher, M. (1993). Perceptual and cognitive aspects of recognition of signs in peripheral vision. In M. Marschark \& M. Clark (Eds.), Psychological perspectives of deafness (pp. 229-265). Hillside, NJ: Lawrence Erlbaum Associates.

Yenisa, M. (2017). The Effectiveness of Using SQ3R Technique in Students' Reading Comprehension of Hortatory Exposition Text. master's thesis, syarif hidayatullah State Islamic University, Jakarta. Retrieved from https://www.pdfdrive.com/the-effectiveness-of-using-sq3rtechnique-in-students-reading-e56022949.html 